\title{
LOS SIGNA EQUITUM O ESTANDARTES IBÉRICOS DE TIPO “JINETE DE LA BASTIDA"
}

\author{
The Signa Equitum or Iberian Standards of "La Bastida Horse Rider” Type
}

\section{MARTÍN ALMAGRO-GORBEA ${ }^{1}$ (D), ALBERTO J. LORRIO ALVARADO ${ }^{2}$ (D, ANA VICO BELMONTE $^{3}$}

(1) Gabinete de Antigüedades, Real Academia de la Historia. teutates1946@gmail.com

(2) Universitat d'Alacant. alberto.lorrio@ua.es

(3) Universidad Rey Juan Carlos. ana.vico@urjc.es

\section{RESUMEN:}

Estudio de 18 figuras de bronce en forma de un jinete con casco, denominadas "Jinetes de tipo La Bastida". Constituyen un grupo de bronces ibéricos de gran interés, pues representan la epipháneia del heros equitans sobre volutas que simbolizan el "Árbol de la Vida” para indicar su carácter sacro y sobrenatural. Se desconoce su contexto arqueológico, pero su estilo jonio-ibérico permite fecharlos desde fines del siglo VI al siglo II a.C. Estos bronces eran la imagen del heros equitans como antepasado mítico de las elites ecuestres que gobernaban la sociedad ibérica, de las que eran el Patrono y Protector. Su popularidad y la presencia por Andalucía de este tipo iconográfico indica la expansión de ejércitos y gentes ibéricas filohelenas, probablemente asociadas a topónimos en Ili-.

Palabras clave: cultura ibérica, bronces ibéricos, armamento ibérico, heros equitans, La Bastida de Mogente, Valencia.

\begin{abstract}
:
Analysis of 18 bronze figures in the shape of a rider with a helmet, called "La Bastida Horse Riders type". They constitute a group of Iberian bronzes of great interest, since they represent the epiphany of the heros equitans on protoaeolian capitals that symbolize the "Tree of Life" to indicate its sacred and supernatural character. Its archaeological context is unknown, but its Ionian-Iberian style allows dating from the end of the 6th century to the 2 nd century $B C$.

These bronzes were the image of heros equitans as a mythical ancestor of the equestrian elites who ruled the Iberian society, of which they were the Patron and Protector. Its popularity and the presence of this iconographic type in Andalusia indicates the expansion of Iberian philhellenic armies and peoples, probably associated with places names beginning with the Iberian word Ili-.
\end{abstract}

Key words: Iberian culture, Iberian bronzes, Iberian armament, heros equitans, La Bastida de Mogente, Valencia. 
En estos últimos años han aparecido en el mercado de antigüedades o en actuaciones clandestinas nuevas figuras ibéricas que representan un jinete y que complementan nuestro conocimiento de un conjunto de bronces que, por su homogeneidad tipológica, pueden denominarse "Jinetes tipo La Bastida" (Lorrio y Almagro-Gorbea 20042005), puesto que el ejemplar más conocido procede del famoso yacimiento de La Bastida de les Alcusses, en Mogente, Valencia, donde fue descubierto hace más de 75 años (Ballester 1932: 27, lám. V,1), aunque su interesante función y significado sólo se ha conocido en estos últimos años.

Estos bronces responden a un mismo modelo iconográfico: un jinete, generalmente desnudo por representarse "heroizado", cuya figura resalta un casco con alta y elegante cimera, que en ocasiones ofrece otros elementos de la panoplia, generalmente una falcata, un escudo y, más raramente, la lanza. Esta figura representa a un jinete heroico en actitud de epipháneia o aparición repentina. Estas figuras se interpretan como signa equitum o estandartes ecuestres y seguramente regios, pues coronaban

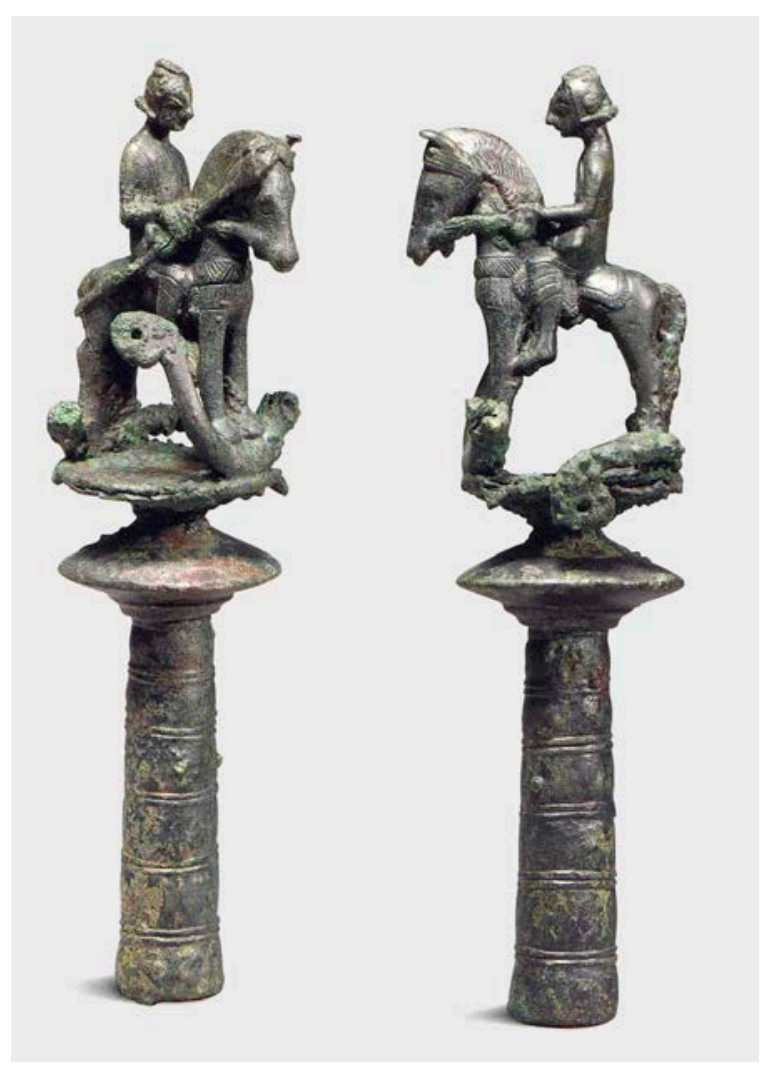

Fig. 1: "Jinete Rupert Wace" (Wace 2011). un vástago o enmangue en el que se insertaba un astil de madera. El jinete se alza sobre sendos pares de volutas que esquematizan capiteles protoeólicos, a modo de "Árbol de la Vida", lo que confiere a estas figuras un marcado carácter sacro de profundo contenido político e ideológico.

El aumento de estas figuras de jinete actualmente conocidas, casi una veintena, permite establecer su tipología, realizar su seriación, precisar su datación, interpretar la ideología que refleja su interesante iconografía y analizar su dispersión geográfica, para deducir su función social y su significado histórico, lo que requería ofrecer una visión de conjunto.

\section{DESCRIPCIÓN, TIPOLOGÍA Y DATACIÓN}

\section{TIPO IA}

\section{1. “JINETE RUPERT WACE” (fig. 1)}

Figura de bronce realizada en dos piezas soldadas entre sí, una es el jinete sobre su caballo, fundido a la cera perdida, y otra el soporte sobre el que ha sido soldado. Las patas del caballo reposan sobre dos largos vástagos redondeados a modo de creciente, que se alzan y rematan en sendas volutas con un orificio central y se apoyan en una placa circular dispuesta sobre una doble moldura circular bitroncocónica de cuya parte inferior sale un vástago hueco decorado con seis molduras horizontales en forma de doble toro que constituiría el enmangue de la pieza.

El jinete, de buena calidad plástica, viste una larga túnica cuyos pliegues llegan hasta la pantorrilla y ofrece los rasgos de la cara estilizados, con una fuerte nariz, ojos almendrados salientes y la boca y el mentón señalados. El caballo muestra los rizos de las crines marcados por líneas sinuosas grabadas, uno de los cuales cae sobre la frente por el lado izquierdo y tiene una larga cola que cae entre las piernas. Está ricamente enjaezado y muestra un pechopetral decorado con triángulos incisos que sale de debajo de la silla, en forma de piel de animal y con el borde decorado con trazos. El caballo lleva dos bridas, que el jinete coge únicamente con su mano izquierda, pues en la derecha porta una lanza en disposición oblicua a lo largo del cuerpo del animal. El jinete completa su armamento con una falcata horizontal adosada al cinturón y un casco casi esférico con un reborde o cubrenuca que remataría en su parte superior con un penacho, roto y perdido, pues sólo se conserva el arranque.

Dimensiones: Altura total: $14 \mathrm{~cm}$. 
Procedencia: Desconocida. Tan sólo se sabe que estaba en una colección privada suiza hacia 1960, de la que pasó a la Galería Rupert Wace de Londres el año 2011 (Wace 2011: $\mathrm{n}^{\mathrm{o}} 30$ ). Actualmente está en paradero desconocido.

Bibliografía: Wace 2011: n 30; Almagro-Gorbea y Lorrio 2011: fig. 17B.

\section{TIPO IB}

\section{2.“JINETE DE LA COLECCIÓN ORTIZ” (fig. 2)}

Figura de bronce a la cera perdida de un jinete vestido con un chitón con escote en pico y mangas cortas y calzado con botas. Lleva la caetra colgada a la espalda y una falcata en su vaina colgada de la cintura de forma transversal. La cabeza ofrece los rasgos de la cara arcaicos pero muy estilizados, en la que destacan los ojos almendrados y una fuerte nariz. Cubre la cabeza un casco semiesférico que debió tener penacho, actualmente perdido, y por su lado izquierdo, por detrás de la paragnátide triangular, sale un largo rizo del cabello acabado en una voluta, que se sobrepone al cubrenuca.

El caballo ofrece una bella estilización del cuerpo y la cabeza, en la que destacan las orejas, y una larga cola, exenta en su arranque pero que se funde entre los cuartos traseros en su parte media y final. Lleva un pechopetral liso, muy marcado, y una silla en forma de piel, pero sólo conserva la brida del lado izquierdo.

Esta figurilla carece de los elementos de sustentación, que parece haber perdido, lo que plantea la posibilidad de que fuera un exvoto y no una figura de jinete de un estandarte ibérico.

Dimensiones: Altura: 6,9 cm. Longitud: $5,1 \mathrm{~cm}$.

Procedencia: En su publicación se supone que procede del área de Sierra Nevada, lo que debe tomarse con reservas. Se conserva en la Colección Ortiz de Ginebra (Ortiz 1996: n² 203)

Bibliografía: Ortiz 1996: no 203.

\section{TIPO IIA}

\section{3.“JINETE DE LA BASTIDA” (fig. 3)}

Esta carismática figura de jinete, hecha a la cera perdida, es la que ha dado nombre a este tipo de figuras, aunque es de factura algo peor que las anteriores y tiene roto y perdido su elemento sustentante.

El jinete, muy estilizado y probablemente desnudo, pues no se sugiere vestimenta alguna, lleva un gran casco

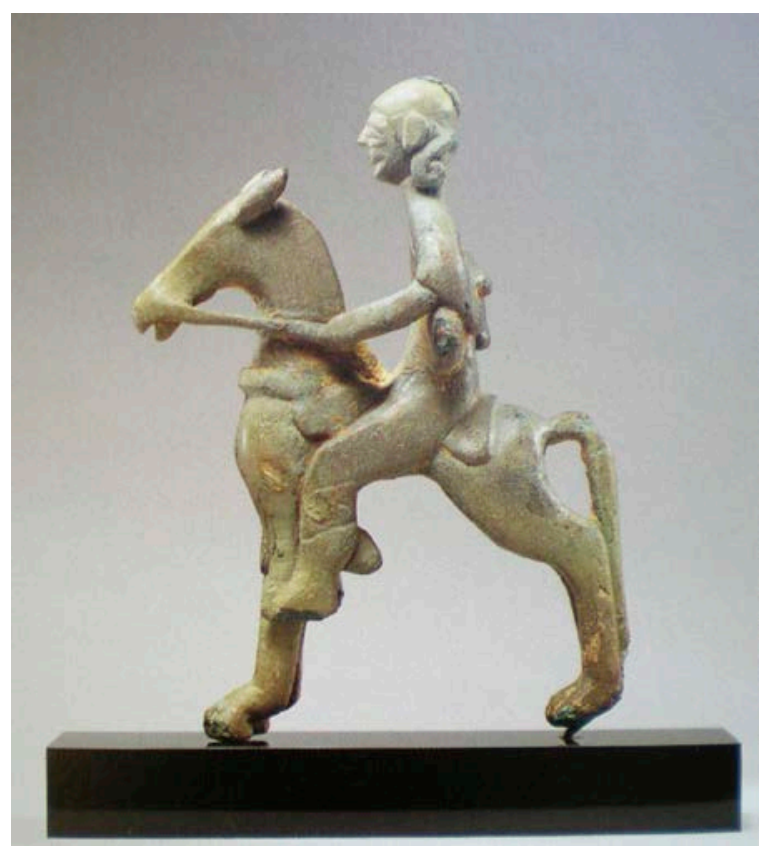

Fig. 2: "Jinete de la Colección Ortiz" (Ortiz 1996: nº 203).

casi esférico con cubrenucas y una gran cimera, que es el elemento más destacado de la figura, que deja libre la cara, en la que se observan los ojos, la nariz y la boca. Su mano derecha, con el codo hacia atrás como en posición de ataque, empuña una falcata horizontal paralela a la brida y cuya punta llega hasta el bocado del caballo, mientras que el brazo izquierdo se extiende en oblicuo hasta la caetra, que queda al lado izquierdo de la cabeza del caballo. Sobre la pierna izquierda, a la altura de la cintura, parece percibirse la vaina de la falcata. El caballo, de medidas desproporcionadas, muestra una cabeza con la boca abierta para el bocado, en la que destacan las orejas casi verticales y un mechón de la crin que cae ondulado por su lado derecho. Presenta una larga cola de sección circular lisa que acaba entre las patas.

Dimensiones: Altura conservada: 7,3 cm. Anchura máxima: 1,5 cm. Longitud máxima: $4 \mathrm{~cm}$. Peso: 53,58 g.

Procedencia: Este jinete es de las pocas piezas de las que se conoce el contexto arqueológico. Fue hallado en 1931 en el oppidum ibérico de La Bastida de les Alcusses, en Mogente, Valencia, fechado de finales del s. V a.C. hasta su incendio y abandono a fines del IV a.C. (Bonet et al. 1997: 270 s.; Bonet 2001: 71; Bonet y Vives-Ferrándiz 2011: 239 s.). Según el diario de excavación, apareció a 45 $\mathrm{cm}$ de profundidad junto a la pared $\mathrm{O}$ del departamento 218 de la llamada "Casa 10", en la zona central de la 


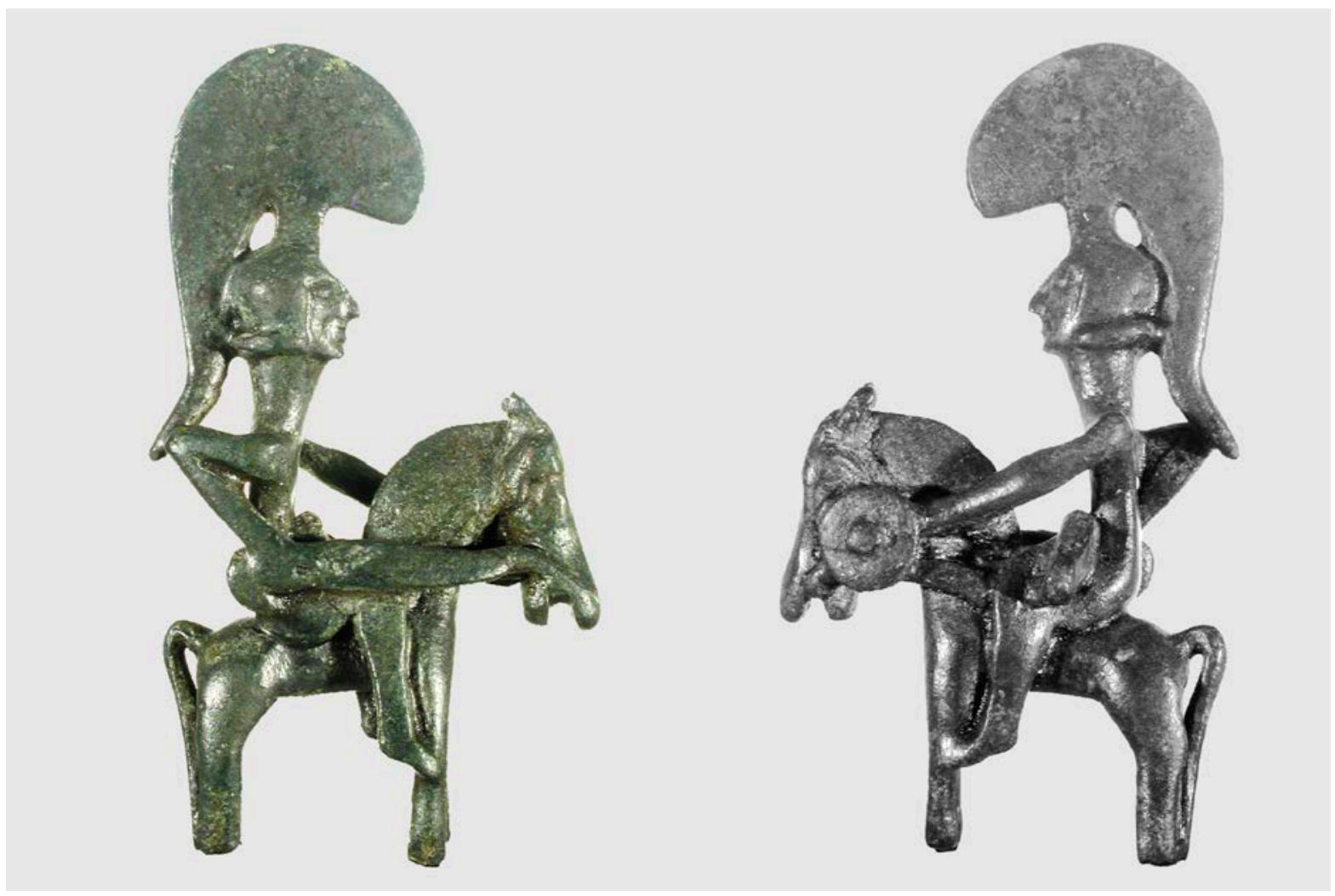

Fig. 3: "Jinete de La Bastida" (Foto Museu de Prehistòria de València).

misma (Ballester 1931: 47 s.). Este edificio debía tener función palacial de quien ostentaba el poder en el poblado, seguramente un monarca, ya que no hay otra vivienda de mayor rango en la población (Díes Cusí y Álvarez García 1998: 336 s.), aunque sus 14 departamentos de $326 \mathrm{~m}^{2}$, con un espacio destinado a un carro como símbolo de estatus (Fernández-Miranda y Olmos 1986: 160 s.; Almagro-Gorbea et al. 2004: 228), han sido considerados en una revisión posterior como dos unidades constructivas separadas por un espacio abierto con no todas las estancias comunicadas (Bonet y Vives-Ferrándiz 2011: 250, fig. 15; VivesFerrándiz 2013). A pesar de esta autorizada opinión, el edificio estaba situado ante la cisterna del poblado en una plaza en prolongación de la calle principal al N, el camino de ronda al S y dos calles transversales en los lados menores (Díes Cusí y Álvarez García 1998: 333 y 335 s.; Lorrio y Almagro-Gorbea 2004-2005: 48) y Moneo (2004: 173) ha señalado que la habitación donde apareció el "Jinete" pudiera considerarse el santuario o espacio destinado a guardar los sacra gentilicia del culto familiar, a juzgar por la aparición del jinete de bronce. Se conserva en el Museo de Prehistoria de Valencia, inv. ${ }^{\circ} 2899$.
Bibliografía: Ballester 1932; Kukahn 1954; Tarradell 1968; Nicolini 1969; Lorrio y Almagro-Gorbea 20042005: fig.1; Bonet y Vives-Ferrándiz 2011: fig. 16).

\section{4.“JINETE BAGOT" (fig. 4)}

Esta figura de bronce quizás se pueda considerar la más destacada del conjunto. A pesar de su pequeño tamaño y su estilización, ofrece un conjunto armonioso, no alejado del naturalismo del arte griego arcaico, por lo que es una destacada obra de estilo jonio-ibérico. Está fundida a la cera perdida en dos piezas soldadas entre sí: una es el cuerpo del jinete sobre el caballo junto con el soporte y otra la cabeza con el casco y el penacho, quizás por una reparación antigua o un fallo en la fusión.

Representa a un guerrero desnudo de estilo naturalista algo estilizado, montado sobre un caballo de poca alzada, casi desproporcionado en relación con el jinete, como ocurre en otros bronces de este tipo (Lorrio y Almagro-Gorbea 2004-2005; Almagro-Gorbea y Lorrio 2007). El jinete cabalga erguido sobre su caballo, al parecer desnudo y sin montura, con la cabeza hacia delante mirando al frente. En el rostro se aprecian los ojos grandes, de forma almendrada 


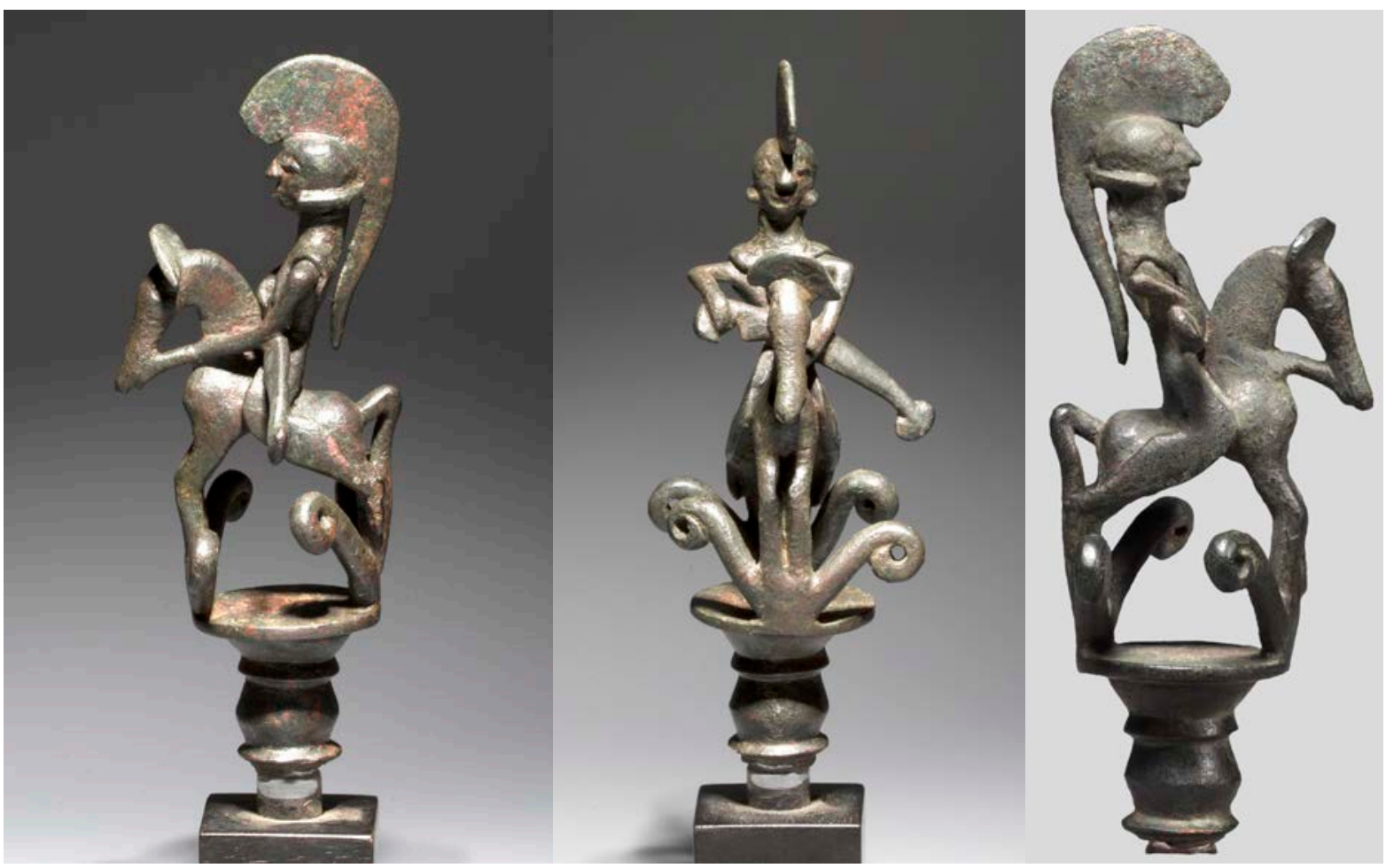

Fig. 4: "Jinete de Bagot" (Foto Galería Bagot).

y algo sobresalientes, una fuerte nariz redondeada y la boca y el mentón redondeado, con detalles algo imprecisos por un cierto desgaste de la superficie de la pieza.

La cabeza queda cubierta por un espléndido casco de forma casi esférica pero abierto por delante, por lo que deja ver la cara. Ofrece guardanuca y un borde resaltado en su parte inferior, y queda rematado por una gran cimera que cae por detrás sin entrar en contacto con la espalda hasta la altura de la cintura del jinete, curvándose levemente a modo de cola de caballo.

El jinete conduce su caballo con el brazo izquierdo, que casi estirado se prolonga en la brida del caballo como un vástago más delgado hasta la cabeza del animal. El brazo derecho, por el contrario, aparece doblado para empuñar o desenvainar una larga falcata o machaira, agarrada al cinturón del jinete, de acuerdo con la disposición característica de los guerreros hispánicos de llevar la espada suspendida transversalmente en la cintura (Quesada 1997: 106). La falcata, muy larga y con ligera curvatura, parece una machaira con la escotadura de la empuñadura perfectamente visible y se prolonga transversalmente hasta sobresalir en el lado opuesto de la figura sobre los remates del vástago de sujeción, donde un ensanchamiento oval representa la contera de la vaina. Las piernas ofrecen una estilización casi cubista con aristas marcadas, el muslo poco desarrollado y la pantorrilla algo exagerada. Están dobladas en ángulo casi recto hacia atrás, por lo que los pies, con el talón bien señalado, quedan paralelos a la cola del caballo, en una postura muy característica.

El caballo, también estilizado, es pequeño y con tendencia a formas redondeadas y a superficies esféricas en las patas, la cola y las bridas, al igual que los brazos del jinete. Sólo tiene brida en su lado izquierdo. Está parado y apoyado sobre sus cuatro patas dispuestas de forma paralela, levemente arqueadas para resaltar los cuartos traseros y la grupa. La cabeza es estilizada sin detalles anatómicos, salvo la frente señalada con un quiebro y el cuello arqueado. Lleva sobre la frente un gran adorno curvado en forma de creciente o abanico en disposición transversal, que contrasta con la cimera del casco del jinete. En su parte posterior, la larga cola del animal, paralela al cuerpo, forma una curva que se eleva ligeramente para caer entre las patas traseras hasta el suelo.

El jinete está dispuesto sobre un soporte característico. Las patas delanteras del caballo aparecen soldadas a una de las volutas, las traseras a la otra y ambas, a su vez, 
a los extremos de la superficie circular que constituye la parte superior del carrete en el que se insertaría el mango de sustentación. La parte superior está formada por una pareja de dobles volutas en cuyo punto de unión se apoyan las patas delanteras y traseras del caballo, ya que constituyen sendos capiteles protoeólicos muy esquematizados, hechos con un grueso alambre de sección circular que forma una espiral, a modo de voluta, en su parte superior ( vid. infra). Estos capiteles de volutas arrancan de los extremos de una plataforma circular, fundida a la cera perdida, en forma de carrete moldurado al exterior y hueca al interior para ensartar el vástago o bastón sobre el que iría la figura ecuestre, como el de la figura similar del Museo de Cuenca $\left(n^{\circ} 7\right)$. La parte superior de esta pieza es un disco plano de borde vertical, dispuesto sobre otra parte troncocónica invertida, que, a su vez, prosigue en otro sector bitroncocónico dispuesto entre dos molduras similares de perfil angulado, cuyas formas geométricas contrastan con las redondeadas y curvadas de la figura del caballo y el jinete.

Dimensiones: Altura: $12,5 \mathrm{~cm}$.

Procedencia: Se desconocen las circunstancias de su hallazgo. Hacia 1970-1980 formaba parte de una colección británica privada, de la que pasó antes de 2016 a la Galería Rupert Wace Ancient Art, de Londres (Wace 2016: ${ }^{\circ}$ 29), y, después, fue adquirida por la Galería Bagot, de Barcelona. Su paradero actual es desconocido, probablemente una colección particular de Barcelona.

Bibliografía: Inédito.

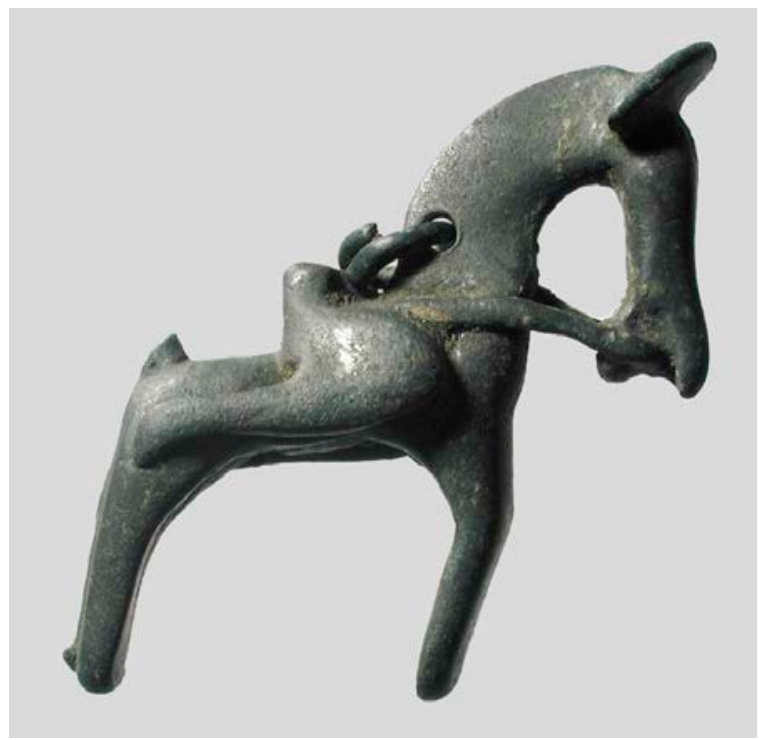

Fig. 5: "Jinete de La Carencia" (Foto Museu de Prehistòria de València).

\section{5. “JINETE DE LA CARENCIA" (fig. 5)}

Figura de bronce de un jinete, hecha a la cera perdida. Está fracturada y falta la parte superior del cuerpo del jinete y la cola del caballo. La base del cuello del animal ofrece una perforación antigua por la que pasa una arandela de bronce quizás para llevar la pieza como colgante.

La parte superior del jinete se ha perdido y sólo se conserva a partir de la cintura, con las piernas dobladas hacia atrás en ángulo recto y pegadas al cuerpo del caballo hasta alcanzar los cuartos traseros del equino, como el Jinete Bagot ( $\left.{ }^{\circ} 4\right)$, el Jinete de Montilla ( $\left.n^{\circ} 5\right)$ y el Jinete Chastel (Addendum). El caballo, muy estilizado con tendencia a formas curvadas suaves, ofrece las patas delanteras y traseras casi unidas y el arranque de la cola hacia arriba. La cabeza muestra las bridas a ambos lados y la boca abierta para el freno y en su parte alta lleva un penacho semicircular en forma de abanico.

Dimensiones: Altura: 4,3 cm. Longitud: $3,8 \mathrm{~cm}$. Anchura: $1,4 \mathrm{~cm}$.

Procedencia: Procede de una incautación de materiales arqueológicos que parecen venir del poblado de La Carencia o de sus alrededores en la zona de Turís, Valencia (H. Bonet y R. Albiach, comunicación personal). Se conserva en el Museo de Prehistoria de Valencia.

Bibliografía: Inédito.

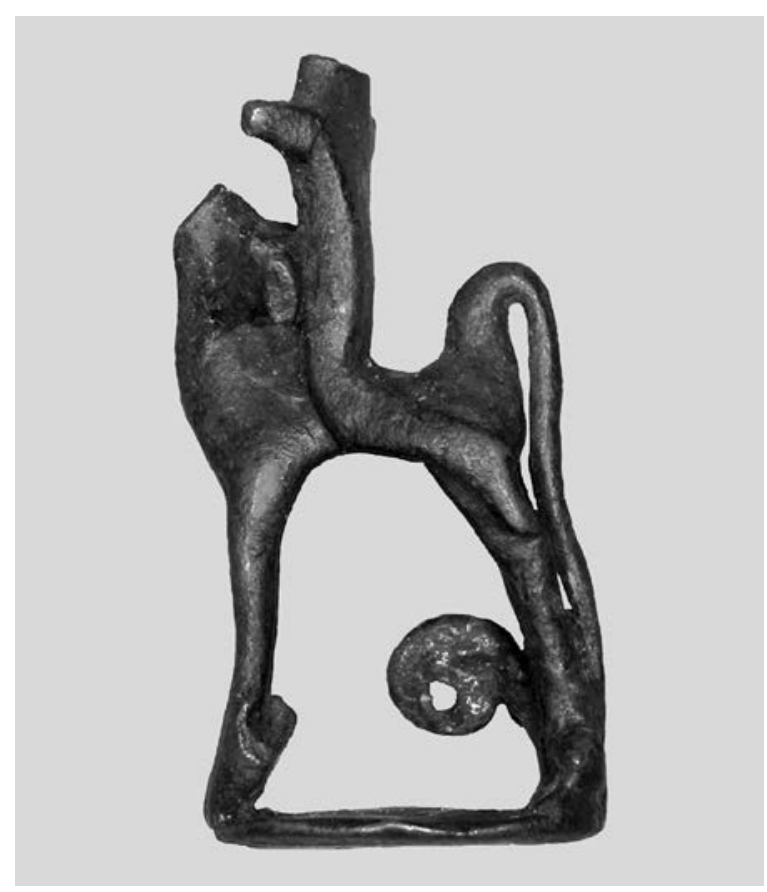

Fig. 6: "Jinete de Montilla”, Córdoba (Foto Museo Histórico Local de Montilla). 


\section{6. “JINETE DE MONTILLA" (fig. 6)}

Figura de jinete fundido a la cera perdida, fragmentada e incompleta, pues le falta la cabeza y los brazos del jinete y cabeza del caballo.

El jinete conserva el torso erguido sobre el caballo de líneas muy simples y estilizadas, con las piernas dobladas hacia atrás con los pies sobre los cuartos traseros del caballo como el Jinete Bagot ( $\left.n^{\circ} 4\right)$ y demás paralelos señalados. Su torso queda prácticamente unido al cuello del animal y entre ambos se aprecia una falcata dispuesta de forma transversal que ha perdido sus dos extremos. El jinete mantiene el arranque de los brazos en alto sin poderse asegurar que sostuvieran las bridas o algún arma.

El conjunto se sitúa sobre una placa circular a la que se han soldado sendas dobles volutas, una de las cuales se conserva completa y con el orificio central, mientras que la otra está rota.

Dimensiones: Altura conservada: $5,80 \mathrm{~cm}$. Longitud máxima conservada del caballo: 2,80 cm. Diámetro de la base: 2,65 cm. Peso: 48,30 g.

Procedencia: Hallazgo casual realizado en 1987 en el Cerro Cocorrón, de Montilla, Córdoba. Se conserva en el Museo Histórico Local de Montilla, Córdoba, en el que ingresó el 7 de julio de 1992, con el nº inv. 52/ COCOR-1 (http://museohistorialocaldemontilla.blogspot.com/2013/04/).

Bibliografía: Lorrio 2006: fig. 1; Almagro-Gorbea y Lorrio 2007: fig. 4,1.

\section{TIPO II-B}

\section{7. “JINETE DEL MUSEO DE CUENCA” (fig. 7)}

Figura de jinete realizada en bronce a la cera perdida, retocada posteriormente con cincel según indican marcas oblicuas sobre la rodilla izquierda. Representa un guerrero desnudo sin armas montado sobre un caballo desproporcionado por su pequeña alzada. Va erguido con la cabeza ligeramente inclinada hacia adelante, los brazos doblados en ángulo sosteniendo las bridas, prácticamente horizontales. Las piernas, con muslos, pantorrilla y pies modelados, dobladas en ángulo recto caen en contacto con las patas delanteras del caballo. El rostro ofrece una nariz recta, grandes ojos almendrados salientes, boca pequeña y mentón diferenciado. Lleva un casco de forma semicircular, con guardanuca y borde resaltado, coronado por una alta cimera o penacho que cae por detrás de la cabeza,

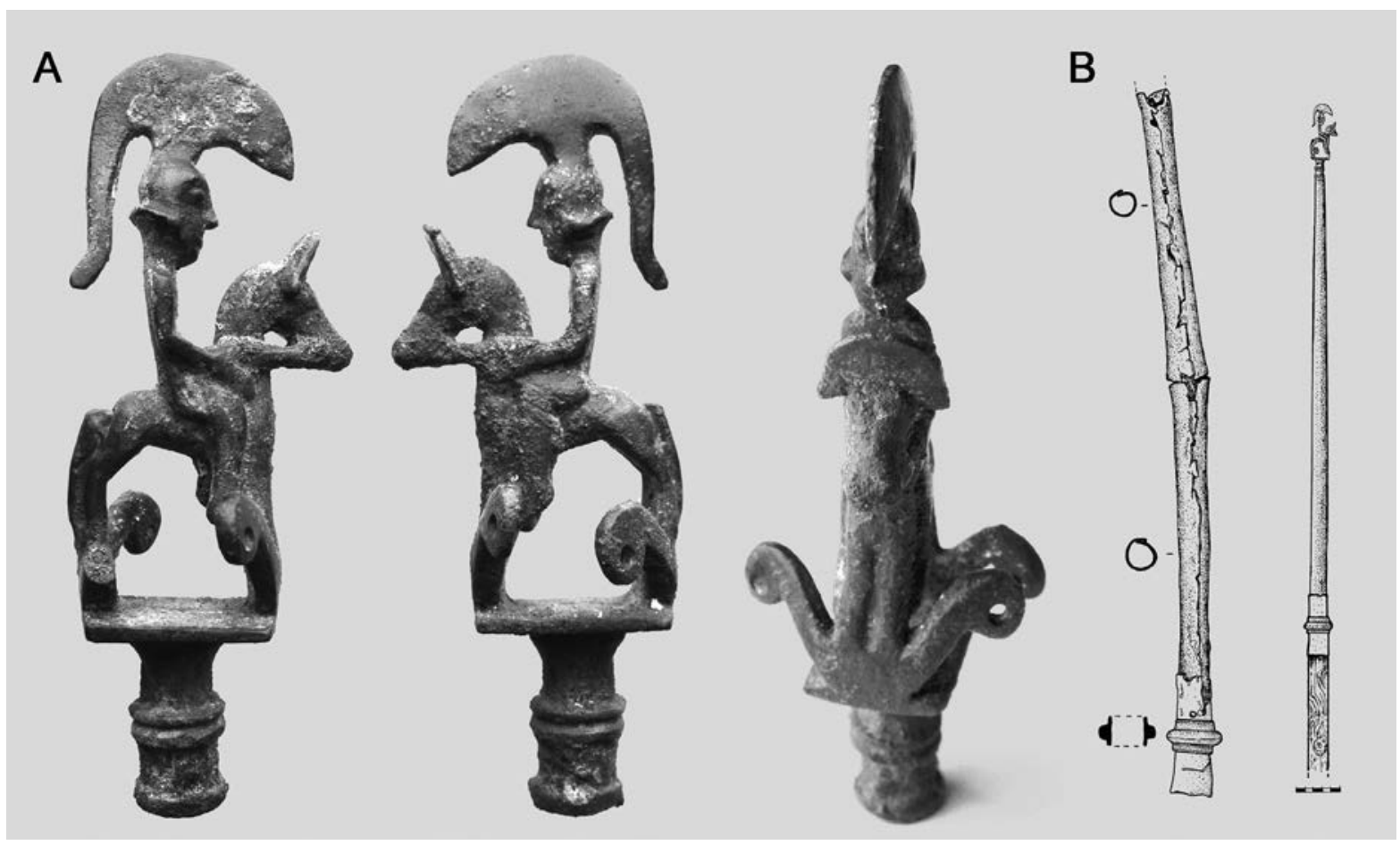

Fig. 7: "Jinete del Museo de Cuenca” y dibujo de su soporte (Almagro-Gorbea y Lorrio 2007: fig. 2). 
sin tocar el capacete ni la espalda, ligeramente curvado hacia el exterior en su extremo.

El caballo está en actitud de descanso apoyado sobre las patas, con la cabeza levantada y una larga cola pegada al cuerpo, que cae entre las patas traseras. El cuerpo es corto y de forma cilíndrica, con la cerviz bien marcada. Ofrece dos bridas y un elegante tocado en forma de creciente que oculta las orejas. Las patas traseras y delanteras se apoyan sobre dos pares de volutas, a modo de sendos capiteles protoeólicos muy esquemáticos, que arrancan del borde de una plataforma rectangular, soldada a un vástago cilíndrico hueco decorado con molduras simples para fijar la pieza a un astil de madera. La conservación de la pieza es buena, aunque ofrece algunas concreciones calizas y ha perdido una de las volutas traseras.

Dimensiones: Altura: $8,5 \mathrm{~cm}$. Altura de la base: 2 $\mathrm{cm}$. Anchura máxima (volutas): $3 \mathrm{~cm}$. Longitud (caballo): $3,15 \mathrm{~cm}$. Dimensiones de la base: 1,75 x $2,13 \mathrm{~cm}$; Diámetro del cilindro: $1,1 \mathrm{~cm}$.; Grosor (cilindro): 0,2 cm. Peso: 52,6 g.

Procedencia: Se desconoce el lugar del hallazgo, que inicialmente se suponía en la zona de Iniesta, Cuenca, aunque según noticias no confirmadas fue hallado en la excavación clandestina de una necrópolis del término

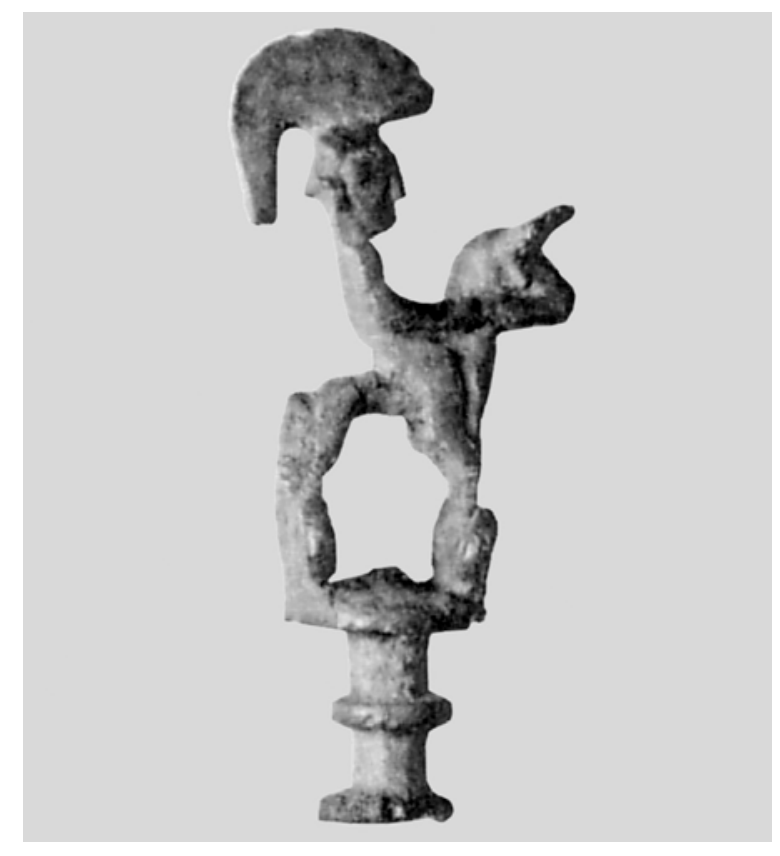

Fig. 8: "Jinete Saint Germain" (Lorrio y Almagro-Gorbea 20042005: fig. 3). municipal de Castillejo de Iniesta. Se conserva desde el año 2001 en el Museo de Cuenca, con el Inv. $\mathrm{n}^{\mathrm{o}} \mathrm{AA01} / 07 / 1598$ (Lorrio y Almagro-Gorbea 2004-2005: 40; Almagro-Gorbea y Lorrio 2007: 19-22).

Bibliografía: Lorrio y Almagro-Gorbea 2004-2005: fig. 2; Almagro-Gorbea y Lorrio 2007: fig. 1 y 2.

\section{8. “JINETE SAINT-GERMAIN" (fig. 8)}

Figura de jinete realizada en bronce a la cera perdida, de características semejantes a los anteriores, pero de factura más tosca. El jinete parece estar desnudo y no lleva armas, salvo un casco redondeado realizado con tosquedad, con guardanuca y resaltado por un penacho cuya parte posterior apenas llega a la altura del cuello. De los rasgos de la cara se aprecia una nariz prominente algo curva, y grandes ojos almendrados. El cuerpo del jinete, en posición erguida y algo echado hacia atrás, tiene los brazos doblados en ángulo recto que se confunden con las bridas y las piernas también en ángulo recto a lo largo de los cuartos delanteros.

El caballo reposa sobre los crecientes de volutas con las patas delanteras y traseras pegadas entre sí, así como la cola que queda alineada en la parte central posterior. Sobre la cabeza del animal el creciente queda como única decoración pues no porta ni silla ni piel en su lomo.

El caballo ofrece una alzada desproporcionada en relación al jinete, con el característico tocado en forma de abanico sobre las orejas. Se alza sobre dos pares de volutas que se apoyan sobre la parte alta de un soporte cilíndrico y hueco, con dos toscas molduras anulares en los extremos y otra en su centro.

Dimensiones: Altura total: $6,8 \mathrm{~cm}$. Anchura total: 2,9 $\mathrm{cm}$. Altura del grupo ecuestre: $3,6 \mathrm{~cm}$. Longitud: $2 \mathrm{~cm}$.

Procedencia: No hay noticias sobre su hallazgo, pues Lantier (1935: 40, nº 4, lám. I,4) lo publicó sin indicar su procedencia. Posteriormente se ha atribuido a un "santuario de la provincia de Jaén" (AA.VV. 1998: $147,329, \mathrm{n}^{\circ} 296$ ), una referencia incierta al interpretarlo como un exvoto de los depositados en el citado museo procedentes de Despeñaperros, Santa Elena, Jaén (Nicolini 1969: 30 s.). Se conserva en el Musée des Antiquités Nationales de Saint-Germain-en-Laye con el inv. $\mathrm{n}^{\circ}$ 77876-04 (https://musee-archeologienationale.fr/ phototheque/oeuvres/cavalier_fondu-a-la-cire-perdu_ bronze).

Bibliografía: Lantier 1935: 40, n 4, lám. I,4; AA.VV. 1998: 147, 329, n 296; Lorrio y Almagro-Gorbea 20042005: fig. 3. 


\section{TIPO II-C}

\section{9. “JINETE DE ESPEJO-1" (fig. 9)}

Figura de jinete hecha de bronce a la cera perdida. Destaca el tamaño desproporcionado del caballo, cuya cabeza sobresale sobre la del jinete. El jinete está echado hacia atrás, como el Jinete Saint-Germain ( $\left.{ }^{\circ} 8\right)$, con los brazos también levantados y separados del cuerpo y acabados en un ensanchamiento que representa las manos que sostiene las bridas, mientras que las piernas están pegadas a los cuartos delanteros del animal. No lleva armas, tan sólo un casco de forma redondeada, con guardanuca y borde resaltado, aunque sólo se conserva el arranque de la cimera, perdida por rotura. La cara muestra la nariz, la boca y los ojos, aunque casi perdidos por su mal estado de conservación. El caballo, en posición estante, lleva el característico tocado en forma de creciente, indicándose la zona de los ojos mediante un resalte, con una larga cola pegada a su cuerpo.

El caballo se alza sobre sendos capiteles de volutas protoeólicas muy toscas, aunque la trasera izquierda falta por rotura. El soporte es un disco circular que se alza sobre un cilindro troncocónico macizo y corto, quizás por rotura, pues le falta la zona hueca para enastar la pieza.

Dimensiones: Altura total conservada: 6,29 cm. Altura hasta la base del soporte: $4,94 \mathrm{~cm}$. Altura conservada del cilindro: 1,18 cm. Anchura máxima (volutas): 2,28 $\mathrm{cm}$. Longitud máxima (caballo): 3,05 cm. Diámetro de la base: $2,3 \mathrm{~cm}$. Grosor de la base: $0,33 \mathrm{~cm}$. Diámetro del cilindro: 1,23-1,51 cm. Peso: 44,3 g.

Análisis metalográfico (PA11821) ${ }^{1}: \mathrm{Cu}: 78,8 \%$; Sn: 6,44 \%; Pb: 13,7 \%; Fe: 0,89 \%; Ni: nd; Zn: nd; As: nd; Ag: 0,062\%; Sb: 0,139\%.

Procedencia: Hallado en el término municipal de Espejo, Córdoba, formó parte de una colección particular de Barcelona y actualmente se conserva por generosa donación de su dueño, el Dr. Mariano Fernández Fairén, en el Gabinete de Antigüedades de la Real Academia de la Historia. Las noticias recabadas por el Dr. Fernández Fairén relativas al lugar del hallazgo de las dos piezas de Espejo ( $\mathrm{n}^{\circ} 9$ y 16 ) resultan contradictorias, proponiéndose que pudieron haberse encontrado tanto en el propio núcleo urbano, al realizar la construcción de una casa, como en las inmediaciones de la localidad, hacia el E o SE, en el límite con Castro del Río, en dirección a la localidad de Nueva Carteya.

Bibliografía: Lorrio y Almagro-Gorbea 2004-2005: fig. 4.

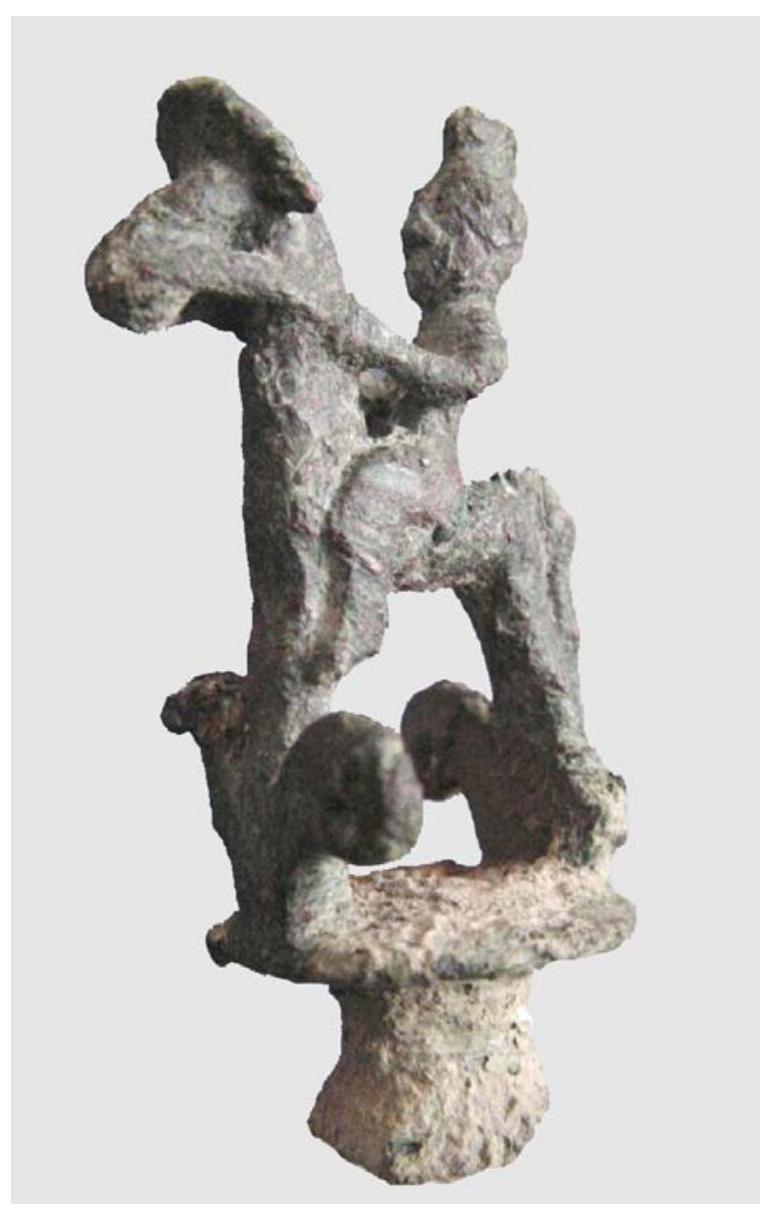

Fig. 9: "Jinete de Espejo-1", Córdoba (Lorrio y Almagro-Gorbea 2004-2005: fig. 4).

\section{0. “JINETE DEL INSTITUTO DE VALENCIA DE DON JUAN” (fig. 10)}

Figura de jinete de bronce fundido a la cera perdida muy fragmentada e incompleta. La figura del jinete prácticamente se ha perdido, quizás porque estaba soldada al caballo, por lo que no se puede saber si llevaba vestimenta o armas, pero se aprecian sus piernas dobladas hacia atrás y quizás un trozo de la falcata que iría colgada transversalmente en la cintura del jinete.

El cuerpo del caballo es muy corto y está inclinado hacia atrás, como si fuera a saltar, pues apoya sus patas delanteras sobre un reborde vertical de la basa del soporte, lo que obliga al animal a flexionar sus patas delanteras, mientras que las traseras quedan entre dos elementos verticales en forma de U que salen de la base del soporte, sistema que ha sustituido a los dos pares de volutas características. No se 


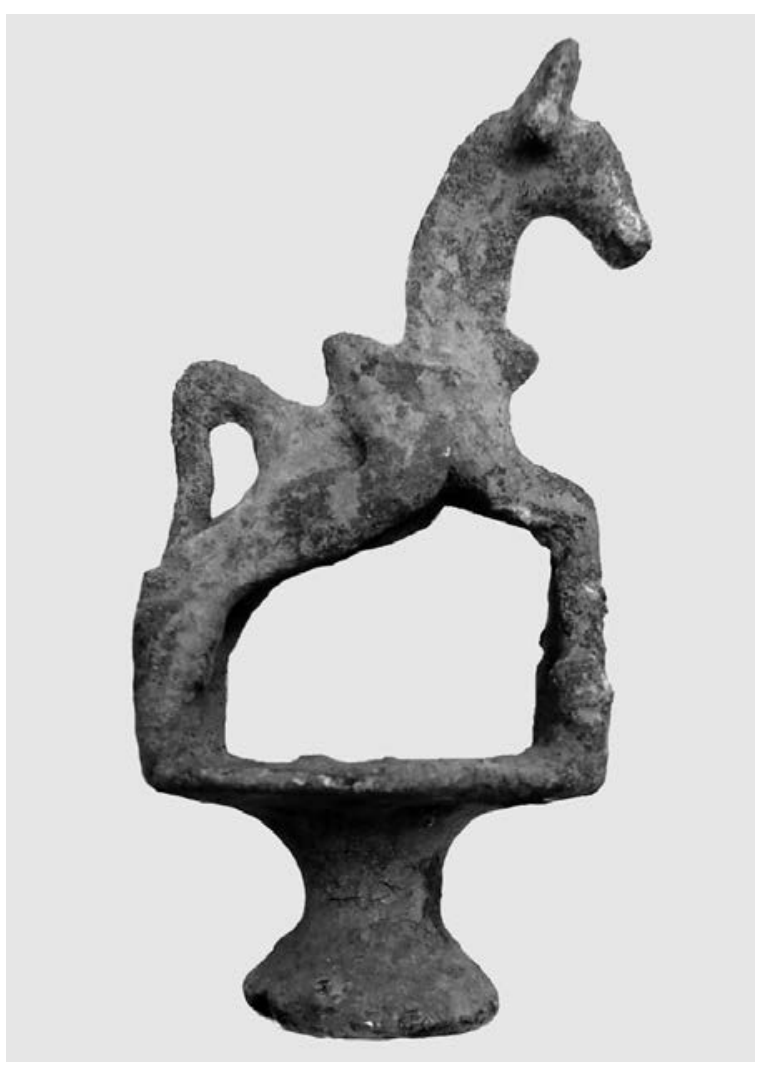

Fig. 10: “Jinete del Instituto de Valencia de Don Juan” (Foto R. Graells).

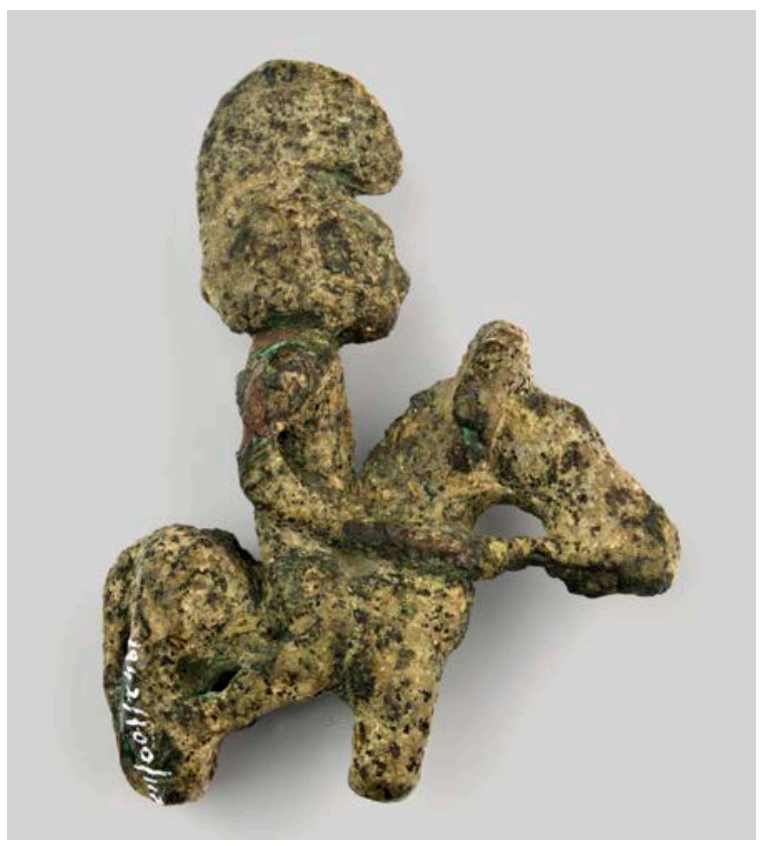

Fig. 11: Jinete de la Colección Heiss (Foto MAN 1942-100-117). aprecia la silla ni las bridas, pero la cabezada ofrece el habitual adorno en forma de creciente y la cola, de sección cilíndrica, forma un arco antes de descender entre las patas traseras. La base de apoyo es una plataforma circular situada sobre un soporte bitroncocónico en forma de huso.

Dimensiones del jinete: Altura: $5 \mathrm{~cm}$. Longitud.: 3,1 $\mathrm{cm}$. Grosor: 1,4 cm. El soporte mide 1,6 cm de altura y su diámetro es de $2,9 \mathrm{~cm}$ en la parte alta y de $1,8 \mathrm{~cm}$ en la inferior.

Procedencia: No hay noticias de su hallazgo, pero se supone que procedería del santuario del Collado de los Jardines, Santa Elena, Jaén, aunque esta procedencia le ha sido atribuida al interpretarlo como un exvoto ibérico. Se conserva en el Instituto del Conde de Valencia de Don Juan, inv. $n^{\circ} 2615$.

Bibliografía: Moreno 2006: 504, nº 231.

\section{JINETE HEISS (fig. 11)}

Figura de un jinete, fundida a la cera perdida. Es de formas y estilo toscos y su superficie está muy corroída y alterada. El jinete parece estar desnudo, lleva un casco cuya cimera no rebasa la cabeza y tiene las piernas hacia atrás con los pies sobre las ancas del caballo. Éste está parado con la cola pegada al cuerpo. La figura ha perdido su base y el soporte que debió tener y también falta el antebrazo izquierdo del jinete por estar roto.

Dimensiones: Altura: $6,5 \mathrm{~cm}$.

Procedencia: No hay noticias sobre su hallazgo. Se conserva en el Museo Arqueológico Nacional procedente de la Colección A. Heiss, adquirida en 1942, con $\mathrm{n}^{\circ}$ inv. MAN 1942/100/117.

Bibliografía: Inédito.

\section{TIPO II-D}

\section{2. “JINETE DE PINOS PUENTE" (fig. 12)}

Figura de jinete fundida a la cera perdida en actitud de parada. Está dispuesto sobre una plataforma de planta circular sostenida por un soporte calado roto, por lo que, en la disposición actual, se ha incrustado en una peana sintética para facilitar su sustentación.

La figura representa un jinete muy estilizado y bastante tosco, con las piernas que caen a lo largo de las patas delanteras del caballo. Lleva un casco casi esférico con guardanuca que queda coronado por una gran cimera que cae hasta el final de la espalda, sin llegar a tocarla. Del rostro apenas se aprecia la nariz prominente. La figura 
ofrece los brazos doblados que se prolongan en las dos bridas y a la cintura lleva una falcata colgada de forma transversal al cuerpo, con la contera de la vaina acabada en un ensanche. La cabecera del caballo ofrece sobre las orejas el característico adorno semicircular en forma de abanico o de creciente invertido y por su parte posterior la cola, de sección cilíndrica, cae hasta el suelo.

Las patas delanteras y traseras del caballo se sostienen sobre sendos soportes en forma de doble voluta con una perforación en su extremo, por la que pasan arandelas de bronce, que, más que para colgar la figura, debieron servir para suspender de ellas algún elemento sonoro a modo de tintinabulum. Estas dobles volutas se sueldan a la parte superior circular de un elemento convexo en forma de huso de cuya parte inferior salen unas tiras de bronce, probablemente ocho, que formarían un elemento de forma esférica calado, como el que ofrece el Jinete de la Colección Segarra ( $\left.{ }^{\circ} 13\right)$, el Jinete del Archivo Cabré $\left(n^{\circ} 15\right)$ y el Jinete de Hornachuelos ( $\left.n^{\circ} 16\right)$.

Dimensiones: Altura: 8,3 cm.

Procedencia: No hay noticias sobre su hallazgo. Apareció en el mercado internacional de antigüedades el año 2008 procedente de una colección alemana en la que se conservaba desde 1966 y fue dado a conocer por Gorny $\&$ Mosch (2008: Subasta 174, lote $n^{\circ} 324$ ) como procedente de Pinos Puente, Granada, pero no se ha podido confirmar dicha procedencia, aunque dicho lugar corresponde al oppidum ibérico de Ilurco. Su paradero actual es desconocido.

Bibliografía: Gorny \& Mosch 2008: Subasta 174, lote $n^{\circ} 324$.

\section{3. “JINETE DE LA COLECCIÓN SEGARRA” (fig. 13)}

Figura de bronce de un jinete fundido a la cera perdida. El jinete, aparentemente desnudo y sin armas, aparece sobre su caballo ligeramente echado hacia atrás, con unos brazos muy simples suavemente doblados y estirados que se prolongan en las bridas, mientras las piernas algo dobladas caen casi en vertical y paralelas a las patas delanteras del caballo. Lleva un casco circular con una gran cimera, muy curvada hacia delante y hacia atrás, por donde llega hasta tocar la espalda. Cubre toda la cabeza por lo que sólo se ve la cara con unos grandes ojos ovalados y una nariz prominente. El casco parece de tipo corintio, pues los laterales se prolongan hacia la cara, pero pudiera ser hispano-calcídico si la citada prolongación se interpreta como las paragnátides o carrilleras.

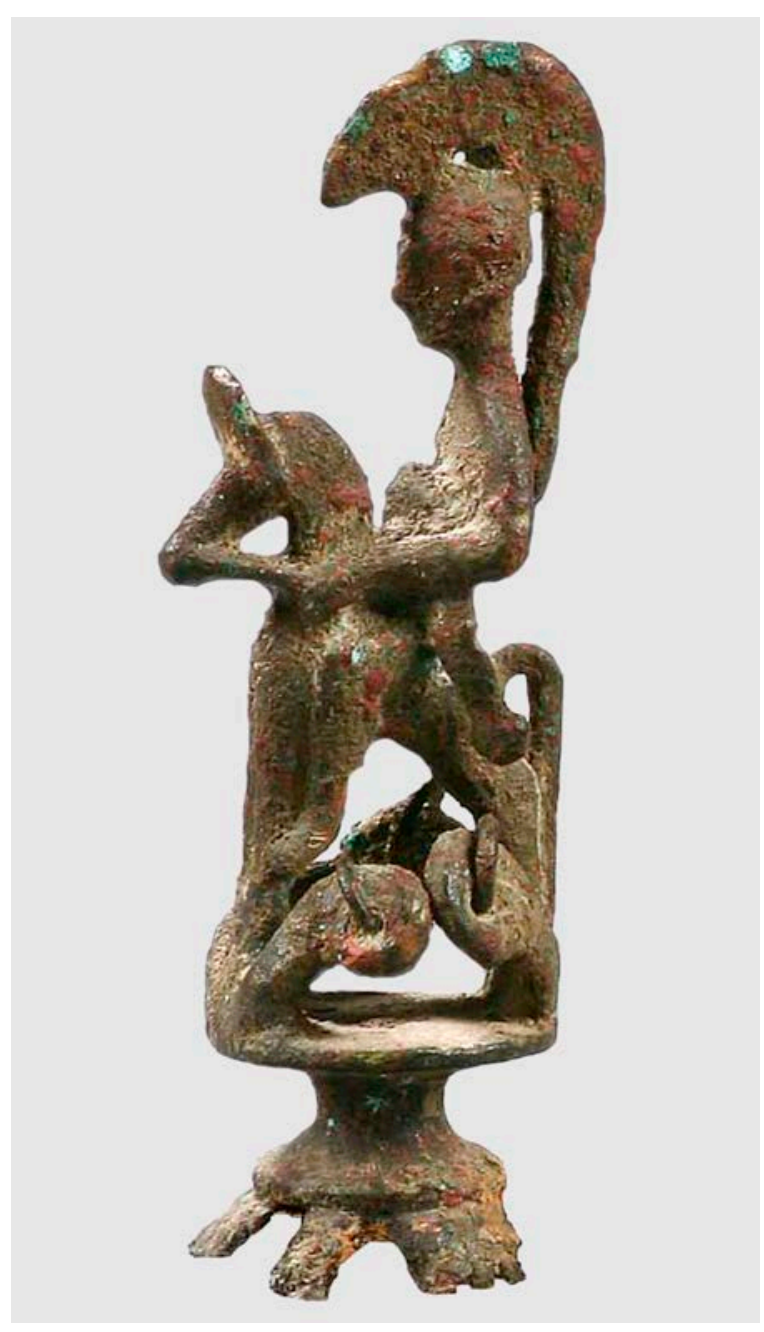

Fig. 12: "Jinete de Pinos Puente”, Granada (Gorny \& Mosch 2008).

El caballo es tosco y de pequeña alzada y se ha representado en posición estante, con la cola pegada a las patas traseras. Tampoco se conservan las bridas ni las orejas del animal. De los rasgos de éste sólo se aprecia la boca abierta y el adorno de forma semicircular en abanico en la parte alta de la cabeza.

La figura está colocada sobre una plataforma circular, ligeramente inclinada al exterior. De su borde salen las dos toscas dobles volutas características, en cuyo centro se apoyan las patas delanteras y traseras del caballo. A su vez, la plataforma se prolonga en un tubo circular de sustentación en cuyo centro ofrece un ensanche globular hueco ligeramente achatado que está formado por cuatro dobles gruesas tiras, ensanche que queda dispuesto entre dos simples molduras anguladas. El 


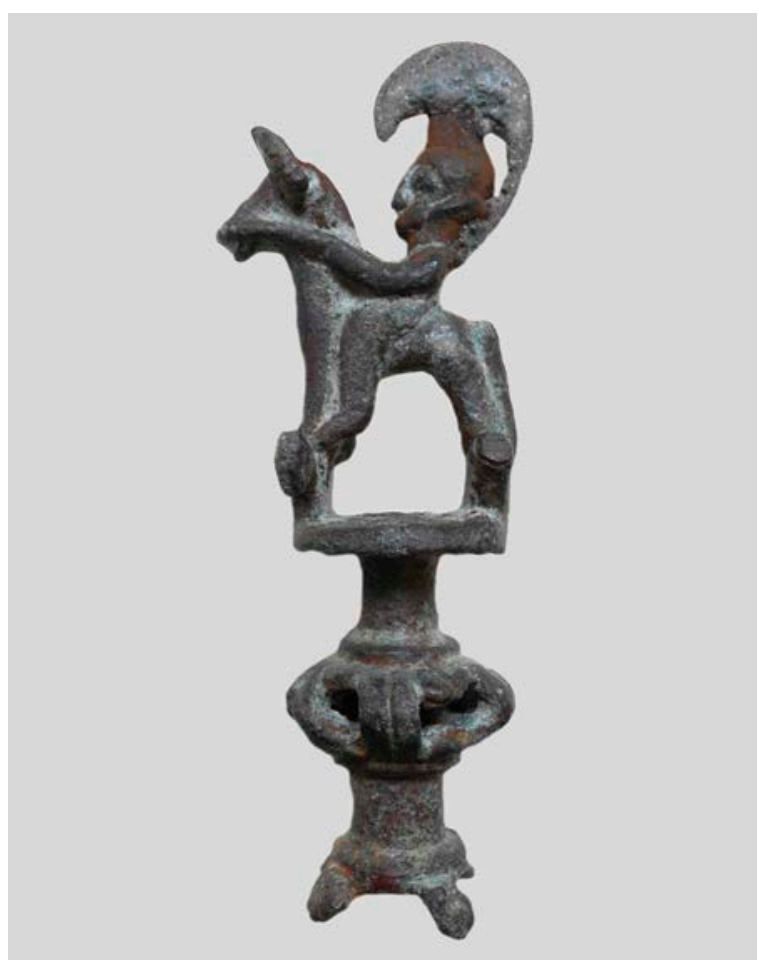

Fig. 13: "Jinete Segarra" (Foto R. Graells).

tubo de sustentación prosigue con un nuevo ensanche globular semejante al anteriormente descrito, pero con las cuatro tiras en disposición contraria. La parte inferior está rota y se ha perdido, por lo que se desconoce su altura y el resto de esta estructura que permitía fijar la pieza al astil de madera.

Dimensiones: Altura total conservada: $10,7 \mathrm{~cm}$. Altura del jinete: 5,8 cm. Longitud del caballo: $3,9 \mathrm{~cm}$. Diámetro del tubo de sustentación: $1,1 \mathrm{~cm}$.

Procedencia: Se desconoce su procedencia. Se conserva en la Fundació Privada per l'Arqueologia Ibèrica de Figuerola del Camp, Tarragona.

Bibliografía: Inédito.

\section{TIPO III}

\section{4. "JINETE DEL ARCHIVO CABRE" (fig. 14)}

Figura de jinete hecha de bronce a la cera perdida y dispuesta sobre un soporte calado. Está muy corroída y no se conoce su paradero actual, por lo que sólo se puede documentar a través de dos fotografías que reproducen las dos vistas laterales de la pieza, conservadas en el Archivo Juan Cabré del IPHE.

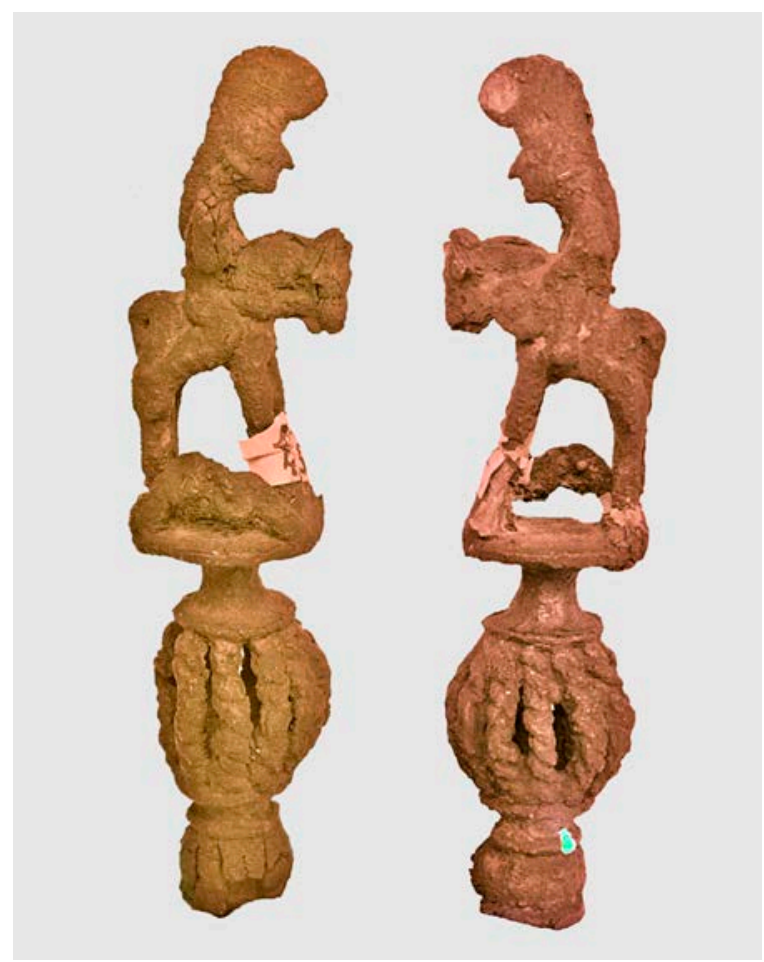

Fig. 14: "Jinete del Archivo Cabré" (Foto Archivo Cabré. IPH. Ministerio de Cultura).

La figura es tosca y desproporcionada, pues el jinete es mayor que el caballo. El jinete lleva un casco con gran penacho cuya parte posterior parece adosarse a la espalda. Su cuerpo aparece curvado con los brazos doblados que se prolongan en las bridas y con las piernas flexionadas hacia atrás hasta los cuartos traseros del caballo, al tiempo que con la mano izquierda sostiene una caetra. El caballo ofrece una postura estante, con los cuartos traseros más cortos. Las patas del caballo reposan sobre una placa circular en la que se conservan las volutas de uno de los laterales y que constituye la parte superior de una pieza convexa, en forma de huso, que finaliza en otra placa circular menor que enlaza con un elemento calado de forma globular formado por 12 alambres torsionados que a su vez reposa en otra pieza convexa en forma de huso más pequeña y aplanada que se adapta a otra pieza globular similar a la anterior, pero de menor tamaño.

Dimensiones: Desconocidas.

Procedencia: Se desconoce su procedencia y su paradero actual, ya que sólo se conserva la fotografía del Archivo Juan Cabré, fotos $n^{\circ} 0982$ y 0983, actualmente en el IPHE del Ministerio de Cultura, pero sin más referencias. Bibliografía: Almagro-Gorbea y Lorrio 2007: fig. 3,7. 


\section{5. "JINETE DE HORNACHUELOS" (fig. 15)}

Figura de bronce de un jinete fundido a la cera perdida. Está fragmentado a la altura de la cintura, por lo que le falta la cabeza y el tronco, así como parte de la cola del caballo.

El jinete debía estar erguido, con las piernas ligeramente dobladas y caídas casi en vertical junto a las patas delanteras del caballo. Éste es de formas muy estilizadas con largas patas, crines moldeadas y una cola que debía estar separada de los cuartos traseros y tampoco se conservan las bridas ni las orejas del caballo.

La figura está dispuesta sobre una plataforma circular, sin las volutas características, que remata un vástago cilíndrico para el enmangue que ofrece en su parte central un ensanche globular hueco formado por cuatro gruesos hilos que imitan un torsionado dispuesto entre dos molduras. Junto al borde de la zona inferior, ligeramente ensanchada hacia la base, se observa una perforación para fijar la pieza al astil de madera

Dimensiones: Altura total $10,2 \mathrm{~cm}$. Altura del jinete: $4,8 \mathrm{~cm}$. Longitud del caballo: $3,8 \mathrm{~cm}$. Diámetro del tubo de sustentación: $3,8 \mathrm{~cm}$.

Procedencia: Esta pieza, junto a la de La Bastida $\left(n^{\circ} 3\right)$, son los dos únicas cuyo contexto arqueológico es conocido. Procede de la necrópolis de El Peñascón, perteneciente al oppidum de Hornachuelos, en Ribera del Fresno, Badajoz (Rodríguez Díaz 1991; 2003; Rodríguez Díaz et al. 2019), identificada tentativamente con la población de Fornacis (Ptol. II,4,10), en la Baeturia Celtica (Rodríguez Díaz 1991; 1995a: 166 s.; Rodríguez Díaz y Enríquez 2001: 291 y 305). La necrópolis ofrece varias concentraciones de 15 a 20 tumbas de incineración de pobre ajuar en torno a grandes túmulos. El jinete se halló en una tumba completamente arrasada, que formaba parte de uno de los espacios funerarios que rodean a uno de estos túmulos (A. Rodríguez, comunicación personal). Esta organización espacial reflejaría la persistencia en época republicana de una organización suprafamiliar característica (Rodríguez Díaz 1995b: 124, fig. 3; Rodríguez Díaz y Enríquez 2001: 291), similar a la documentada en época prerromana en comunidades vetonas del Tajo Medio y del área abulense (Álvarez-Sanchís 1999: 168 s.). Este contexto funerario se ha datado entre mediados del s. II a.C. y finales del I a.C. (Rodríguez Díaz 2003: 10 s.), aunque el jinete pudiera ser algo anterior, por lo que puede considerarse uno de los más modernos del grupo junto con el Jinete de Espejo $2\left(\mathrm{n}^{\mathrm{o}} 16\right)$, de fecha

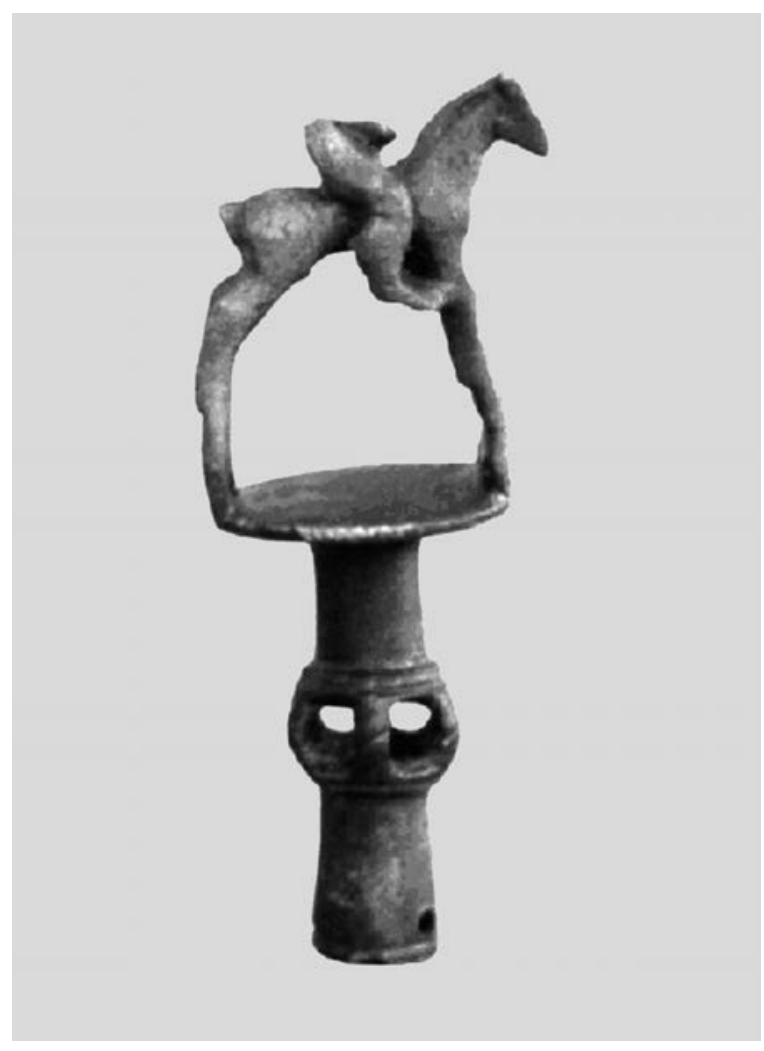

Fig. 15: "Jinete de Hornachuelos", Badajoz (Foto A. Rodríguez).

igualmente avanzada, como confirma la ausencia de un elemento tan representativo como las volutas y su contemporaneidad con los "estandartes celtibéricos" (Almagro-Gorbea 1998; Lorrio 2010; Lorrio y Graells 2011-2012), con los que presenta cierta similitud estructural.

Bibliografía: Rodríguez Díaz 1991; 2003; Rodríguez Díaz et al. 2019: 73; Almagro-Gorbea y Lorrio 2007: fig. 4,3.

\section{6. “JINETE DE ESPEJO-2" (fig. 16)}

Jinete de bronce hecho a la cera perdida, pero de manufactura muy ruda y simple, pues incluso carece del característico soporte de volutas. El jinete, desnudo, aparece pegado a la cabeza del caballo e inclinado claramente hacia atrás, como el del Museo de Saint-Germain-enLaye ( $\mathrm{n}^{\circ} 8$ ), aunque con las piernas rectas y cortas, con los pies bien señalados. Porta como única arma el casco con un penacho prominente pegado al capacete sin el soporte que ofrecen otras piezas, pero en los laterales parecen verse sendos roleos, uno a cada lado, como en los cascos esculpidos en piedra de Porcuna, Jaén (Negueruela 1990: 
fig. 4 bis, 5, 18A, 18B, 19, lám. 5A y B, 7-9, 15-16, 42), aunque también pudieran ser elementos metálicos acoplados a los laterales de los cascos, como en los ejemplares de Porcuna (id:: $131 \mathrm{~s}$.) y en los cascos hispano-calcídicos (Graells et al. 2017). Sostiene las bridas con ambas manos, representadas por toscos trazos paralelos oblicuos. La cabeza es desproporcionada respecto al resto del cuerpo y la cara ofrece un tratamiento muy tosco de ojos, nariz y boca.

El caballo tiene las patas abiertas ligeramente curvadas e inclinadas, como si estuviera frenado. La cola, corta y ligeramente arqueada, cae entre las patas del animal, cuyo sexo está exageradamente representado, detalle único en este grupo de jinetes. También se han representado las orejas puntiagudas del animal y se insinúan sus ojos y la boca entreabierta, pero no se observa en la frente el adorno semicircular característico.

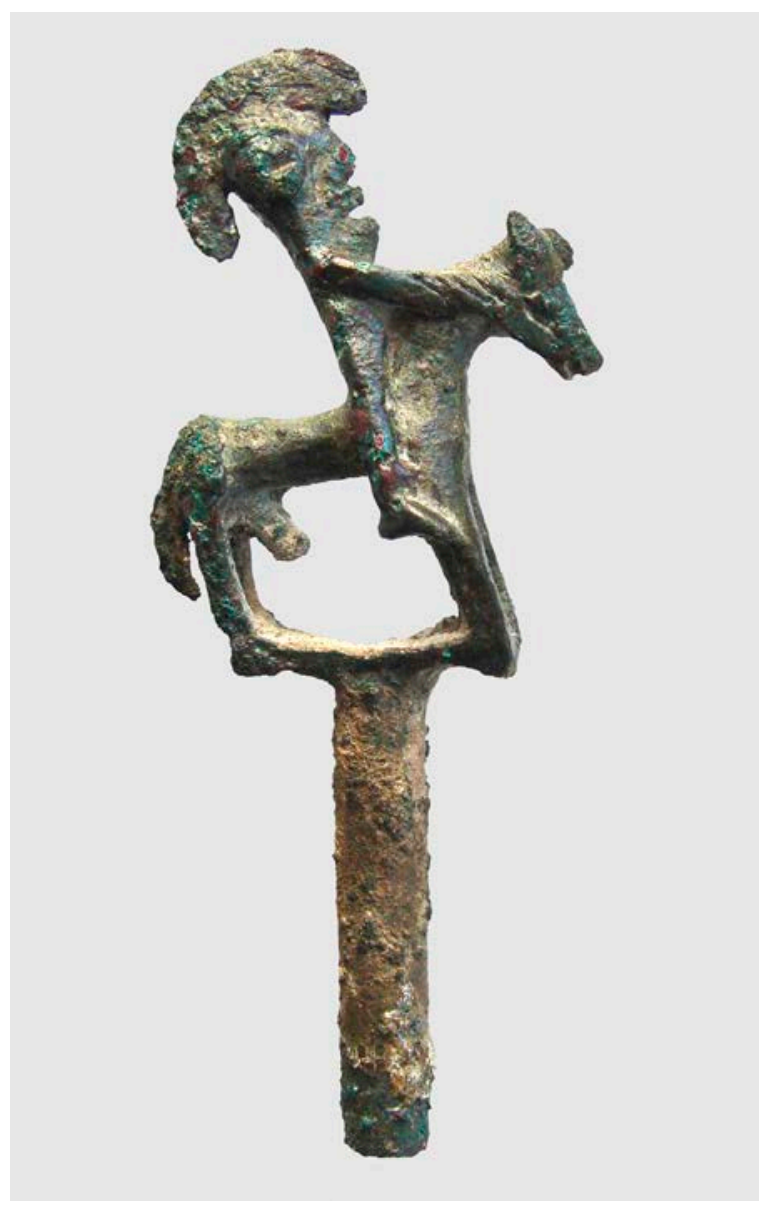

Fig. 16: "Jinete de Espejo-2" (Lorrio y Almagro-Gorbea 20042005: fig. 5).
La figura se alza sobre una placa rectangular irregular sin las volutas características, de la que parte un largo vástago macizo de sección circular, fracturado en su extremo, por lo que esta pieza carece de los soportes tubulares huecos que ofrecen las restantes figuras de jinete.

Dimensiones: Altura total: $12,44 \mathrm{~cm}$. Altura hasta la base del soporte: 7,24 cm. Longitud conservada del vástago: 5,73 cm. Anchura máxima (pies del jinete): 2,16 cm. Longitud máxima (caballo): 5,05 cm. Dimensiones de la base: 3,14 x 1,34 cm. Grosor de la base: $0,39 \mathrm{~cm}$. Diámetro del vástago: $1,1 \mathrm{~cm}$. Peso: 112,45 gr.

Análisis metalográfico

(PA11822b) (casco): Cu: 93,7 \%; Sn: 2,49; Pb: 2,55\%; Fe: 0,61 \%; Ni: nd; Zn: nd; As: nd; Ag: 0,101\%; Sb: 0,555\%.

(PA11822a) (vástago): Cu: 94,0 \%; Sn: 1,82; Pb: 2,71 $\%$; Fe: 0,92 \%; Ni: nd; Zn: nd; As: nd; Ag: 0,071\%; Sb: $0,545 \%$.

Procedencia: Como el Jinete Espejo-1 ( ${ }^{\circ} 9$ ), procede de la zona de Espejo, Córdoba, con noticias contradictorias sobre el lugar del hallazgo (vid. supra, $\mathrm{n}^{\circ}$ 9). Formó parte de una colección particular de Barcelona y actualmente se conserva por generosa donación de su dueño en el Gabinete de Antigüedades de la Real Academia de la Historia.

Bibliografía: Lorrio y Almagro-Gorbea 2004-2005: 44 , fig. 5 .

\section{INCIERTOS}

\section{7. "JINETE HERMANN"}

Se trata de una pieza de estructura bastante compleja, pues el jinete está dispuesto sobre un alto soporte con espirales y cadenillas con elementos colgantes a modo de tintinabula. Estuvo hace unos años en posesión de la casa de subasta Hermann Historica. GmbH, de Munich, pero sólo tenemos de esta pieza noticias orales.

Dimensiones: Desconocidas.

Procedencia: Se desconoce su procedencia y su paradero actual.

Bibliografía: Inédito.

\section{TIPOLOGÍA}

Estas interesantes figuras de bronce en forma de jinete forman un reducido grupo de características tipológicas bien definidas, aunque con variaciones estilísticas y formales que permiten diferenciarlas sin dificultad de los exvotos ibéricos que representan jinetes, con los que en ocasiones 
se han confundido y con los que ofrecen evidentes semejanzas formales y estilísticas. La singularidad de estos pequeños bronces se ha reconocido en fechas relativamente recientes: en 2005 los ejemplares identificados eran cinco (Lorrio y Almagro-Gorbea 2004-2005), pasaron a ser doce en 2011 (Almagro-Gorbea y Lorrio 2011: Apéndice 3C), número acrecentado en la actualidad hasta los diez y ocho recogidos en esta ocasión, alguno de ellos de especial interés, como el "Bronce Bagot", por lo que su número es seguro que se acrecentará en el futuro.

En la actualidad, las piezas conocidas son las siguientes (vid. supra):

1. "Jinete Rupert Wace" (Wace 2011; Almagro-Gorbea y Lorrio 2011: fig. 12B).

2. "Jinete de la Colección Ortiz" (Ortiz 1996: n 203).

3. "Jinete de La Bastida", Valencia (Ballester 1932: lám. V,I,2; Kukahn 1954; Tarradell 1968: 38; Nicolini 1969: lám. I,6-7; 1977: nº 22; Lorrio y Almagro-Gorbea 2004-2005: fig. 1)

4. "Jinete Bagot" (Wace 2016: n 29).

5. "Jinete de La Carencia", Valencia (inédito, R. Albiach, comunicación personal).

6. "Jinete de Montilla", Córdoba (Lorrio 2006: fig. 1 y 3,6; Almagro-Gorbea y Lorrio 2007: fig. 3,6 y 4,1).

7. "Jinete del Museo de Cuenca" (Lorrio y AlmagroGorbea 2004-2005: fig. 2).

8. "Jinete Saint-Germain" (Lantier 1935: 40, n 4, lám. I,4; AA.VV. 1998: 147, 329, no 296; Lorrio y Almagro-Gorbea 2004-2005: 42, fig. 3).

9. "Jinete de Espejo-1", Córdoba (Lorrio y AlmagroGorbea 2004-2005: fig. 4).

10. "Jinete del Instituto de Valencia de Don Juan" (Moreno 2006: 504, n 231).

11. "Jinete Heiss" (inédito).

12. "Jinete de Pinos Puente", Granada (Gorny \& Mosch 2008: Subasta 174, no 324).

13. "Jinete Segarra" (inédito).

14. "Jinete del Archivo Cabré" (Almagro-Gorbea y Lorrio 2007: fig. 3,7 y 4,2)

15. "Jinete de Hornachuelos", Badajoz (Rodríguez Díaz 1991; 2003; Almagro-Gorbea y Lorrio 2007: fig. 4,3).

16. "Jinete de Espejo-2", Córdoba (Lorrio y Almagro-Gorbea 2004-2005: fig. 5)

17. "Jinete Hermann" (inédito).

18. "Jinete Chastel" (Addendum)

Estos jinetes forman un conjunto polimorfo con características comunes, aunque ninguna de las piezas ofrece todas las características ni ninguna característica aparece en todas las piezas (Clarke 1968: 149 s.), salvo el jinete heroico, que define a este conjunto de bronces ibéricos. A partir de este hecho y del estilo que ofrecen, se pueden relacionar unas piezas con otras para seriarlas y determinar su tipología y cronología relativa al precisar la evolución de las características formales y estilísticas del conjunto (fig. 17), mientras que su cronología absoluta, a falta de contextos arqueológicos conocidos, se debe establecer gracias a su estilo y al armamento que lleva el jinete, en el que destacan un casco con gran penacho y una falcata, elementos que indican la función y el significado ideológico de estas representaciones tan características de la Cultura Ibérica.

Estos "Jinetes tipo La Bastida" pueden seriarse a partir de la secuencia de los elementos que ofrecen: lanza, silla de piel, rizo lateral del jinete o del caballo, soporte de volutas, vástago tubular, casco con penacho, falcata al cinto, caetra, falcata empuñada, jinete desnudo, piernas hacia atrás, adorno en la cabezada del caballo, ausencia de armas y soporte calado. La seriación de estas características ofrece una secuencia que permite diferenciar tres grupos tipológicos con variantes internas que responden a tres fases cronológicas sucesivas (fig. 17).

Sin embargo, tampoco de debe excluir que pudieran proceder de tres escuelas/talleres distintos que funcionan en paralelo ${ }^{2}$, puesto que si se acepta la larga perduración que se propone más adelante, sería el modelo tipológico e iconográfico más estable del Mediterráneo en esas fechas, lo que sorprende comparado con otros tipos de objetos metálicos de la península Ibérica, a lo que se añade su relación con comportamientos sociales y realidades culturales que tendrían esa longevidad. La alternativa más lógica en ese caso sería pensar en su vigencia en el s. V a.C. con tres escuelas paralelas, hecho acorde con las armas y su iconografía, ya que llevarlos hasta fechas mucho más tardías implicaría la vigencia iconográfica del modelo y de los objetos, lo que puede ser discutible.

El Grupo I es el más antiguo y puede considerarse el "prototipo", pues es anterior al Jinete de La Bastida ( $\left.n^{\circ} 3\right)$ y al Jinete Bagot ( $\left.n^{\circ} 4\right)$, que son sus más próximos paralelos, pero ya ofrece las características propias del conjunto, como la disposición del jinete enhiesto sobre su caballo parado y el soporte de volutas. Su calidad estilística es superior a la mayoría de las piezas, pues las figuras están modeladas con más cuidado, con ojos almendrados de tipo arcaico, ofrecen detalles retocados a buril y usan una piel como ephippium o montura del caballo, elemento que desaparece posteriormente. El Grupo I lo forman 


\begin{tabular}{|c|c|c|c|c|c|c|c|c|c|c|c|c|c|c|c|c|c|}
\hline & IA & $1 \mathrm{~B}$ & IIA & IIA & IIA & IIA & IIB & IIB & IIC & IIC & IIC & IID & IID & IID-III & IID-III & III & $?$ \\
\hline & $I$ & 2 & 3 & 4 & 5 & 6 & 7 & 8 & 9 & 10 & 11 & 12 & 13 & 14 & 15 & 16 & 17 \\
\hline & RW & JO & LB & JB & LC & Mon & MC & StG & Es-1 & IVDJ & Hei & PP & JS & $\mathrm{AC}$ & JH & Es-2 & $J H$ \\
\hline Lanza & $\mathrm{X}$ & & & & & & & & & & & & & & & & \\
\hline Silla de piel & $\mathrm{X}$ & $\mathrm{X}$ & & & & & & & & & & & & & & & \\
\hline Rizo lateral & $\mathrm{X}$ & $\mathrm{X}$ & $\mathrm{X}$ & & & & & & & & & & & & & & \\
\hline Soporte de volutas & $\mathrm{X}$ & $?$ & $?$ & $X$ & $?$ & $\mathrm{X}$ ? & $\mathrm{X}$ & $\mathrm{X}$ & $\mathrm{X}$ & $\mathrm{X}$ & $?$ & $\mathrm{X}$ & $\mathrm{X}$ & & & & $X$ \\
\hline Vástago tubular & $\mathrm{X}$ & $?$ & $?$ & $\mathrm{X}$ & $?$ & $X$ & $\mathrm{X}$ & $\mathrm{X}$ & $\mathrm{X}$ & $?$ & $?$ & & & & & (x) & \\
\hline Casco con penacho & $X ?$ & $?$ & $\mathrm{X}$ & $X$ & $?$ & $?$ & $\mathrm{X}$ & $X$ & $\mathrm{X} ?$ & $?$ & $\mathrm{X}$ & $\mathrm{x}$ & $\mathrm{X}$ & $X$ & $?$ & $\mathrm{X}$ & $X$ \\
\hline 2 Bridas & $\mathrm{X}$ & & $X$ & & $\mathrm{X}$ & $X$ & $\mathrm{X}$ & $X$ & $\mathrm{X}$ & $?$ & $\mathrm{X}$ & $?$ & $\mathrm{X}$ & $X$ & $?$ & $\mathrm{X}$ & $X ?$ \\
\hline Falcata transversal & $\mathrm{X}$ & $\mathrm{X}$ & & $\mathrm{X}$ & $?$ & $\mathrm{X}$ ? & & & & $X ?$ & & $\mathrm{X}$ & & & & & \\
\hline Caetra & & $x$ & $\mathrm{X}$ & & & & & & & & & & & $X$ & & & \\
\hline 1 Brida & & $\mathrm{X}$ & & $\mathrm{X}$ & & & & & & $?$ & & & & & $?$ & & \\
\hline Falcata empuñada & & & $\mathrm{X}$ & $\mathrm{X}$ & & & & & & & & & & & & & \\
\hline Jinete desnudo & & & $\mathrm{X}$ & $\mathrm{X}$ & $\mathrm{X}$ & $\mathrm{X}$ & $\mathrm{X}$ & $X$ & $X$ & $\mathrm{X}$ & $\mathrm{X}$ & $\mathrm{X}$ & $\mathrm{X}$ & $X$ & $\mathrm{X}$ & $\mathrm{X}$ & $X ?$ \\
\hline Piernas hacia atrás & & & & $\mathrm{X}$ & $X$ & $\mathrm{X}$ & & & & $\mathrm{X}$ & $\mathrm{X}$ & & & $\mathrm{X}$ & & & \\
\hline Adono cabezada & & & & $\mathrm{X}$ & $X$ & $X$ & $\mathrm{X}$ & $\mathrm{X}$ & $\mathrm{X}$ & $\mathrm{X}$ & $\mathrm{X}$ & $\mathrm{X}$ & $\mathrm{X}$ & & $?$ & & $X ?$ \\
\hline Sin armas & & & & & $?$ & & $\mathrm{X}$ & $X$ & $\mathrm{X}$ & & $x$ & & $\mathrm{X}$ & $\mathrm{X}$ & $x$ & $\mathrm{X}$ & $?$ \\
\hline Vástago calado & & $?$ & $?$ & & $?$ & $?$ & & & $?$ & $?$ & $?$ & $X$ & $X X$ & $X$ & $X$ & & $X ?$ \\
\hline
\end{tabular}

Fig. 17: Seriación tipológica de los "Jinetes tipo La Bastida".

el Jinete Wace $\left(\mathrm{n}^{\mathrm{o}} 1\right)$ y el Jinete Ortiz $\left(\mathrm{n}^{\mathrm{o}} 2\right)$. Esta última pieza, si realmente es el remate de un signum equitum, parece algo posterior a la anterior, ya que comparte características que prosiguen en el Grupo II, como el mechón de pelo lateral, propio de los bronces ibéricos del "grupo de los rizos largos" (Almagro-Gorbea et al. 2004: 228 s.; Almagro-Gorbea y Lorrio 2011: 302).

El Grupo II es el más importante de estos estandartes ecuestres, pues está formado por 12 piezas que comparten características similares, un 66,6\% del total. En este Grupo II pueden distinguirse cuatro variantes o subgrupos. Un subgrupo IIA lo forman el Jinete de La Bastida $\left(n^{\circ} 3\right)$ y el Jinete Bagot $\left(n^{\circ} 4\right)$, quizás la pieza más destacada de todas las conocidas. Junto a ellas se pueden situar el Jinete de La Carencia ( ${ }^{\circ} 5$ ), el Jinete de Chastel (Addendum) y el de Montilla ( $\left.\mathrm{n}^{\circ} 6\right)$, que parecen ofrecer rasgos similares, aunque más estilizados, si bien su rotura impide conocer detalles importantes para su clasificación segura. Un subgrupo IIB lo formarían figuras más toscas, como los jinetes del Museo de Cuenca $\left(\mathrm{n}^{\circ} 7\right)$, de SaintGermain $\left(n^{\circ} 8\right)$ y de Espejo-1 ( $\left.n^{\circ} 9\right)$, mientras que el subgrupo IIC lo integrarían piezas todavía más toscas y con las volutas degeneradas, como los jinetes del IVDJ $\left(n^{\circ} 10\right)$ y de la Colección Heiss $\left(n^{\circ} 11\right)$. Paralelo a los subgrupos IIA, IIB y IIC es el subgrupo IID, caracterizado por tener un soporte calado, un elemento presente tanto en jinetes que estilísticamente se enmarcan sin dificultad en este Grupo II, como los de Pinos Puente $\left(\mathrm{n}^{\circ} 12\right)$ y de la Colección Segarra ( $\left.{ }^{\circ} 13\right)$, como en otros ya más evolucionados, como los del Archivo Cabré ( $\left.n^{\circ} 14\right)$ y Hornachuelos $\left(n^{\circ} 15\right)$.

Es muy significativa la disposición en este Grupo II del jinete sobre un soporte de volutas, que ya ofrece el Jinete Wace del Grupo I y, en especial, su desnudez, que pasa a ser característica de todas las piezas de éste Grupo II, como el casco con amplia cimera y el adorno del caballo en forma de creciente, que todavía no aparece en el Jinete de La Bastida $\left(\mathrm{n}^{\circ} 3\right)$. Este Jinete de La Bastida lleva la falcata en la mano, que también empuña el Jinete Bagot ( $\left.n^{\circ} 4\right)$, en este caso cruzada al ir adosada al cinturón, como en los jinetes de Pinos Puente ( $\left.\mathrm{n}^{\circ} 12\right)$, Montilla ( ${ }^{\circ}$ 6 ) y probablemente en el Jinete del IVDJ $\left(n^{\circ} 10\right)$, frente a los jinetes del Museo de Cuenca ( ${ }^{\circ} 7$ ) y de Saint-Germain $\left(n^{\circ} 8\right)$ que ya no llevan armas. Otro detalle de interés son las piernas dispuestas hacia atrás hasta la grupa del caballo, un detalle desconocido en exvotos ibéricos, que aparece en los jinetes Bagot ( $\left.\mathrm{n}^{\circ} 4\right)$, La Carencia $\left(\mathrm{n}^{\circ}\right.$ 5), Montilla $\left(n^{\circ} 6\right), \operatorname{IVDJ}\left(n^{\circ} 10\right)$, Heiss ( $\left.{ }^{\circ} 11\right)$, Archivo Cabré $\left(n^{\circ} 14\right)$ y Colección Chastel (Addendum).

El Grupo III lo forman jinetes de un estilo claramente degenerado, con una estilización en ocasiones muy ruda, lo que evidencia ejemplares tardíos, pues en dos de ellos $\left(\mathrm{n}^{\circ} 15\right.$ y 16$)$ ya no aparecen las características volutas del soporte. En este grupo III cabría incluir piezas como el 
Jinete del Archivo Cabré ( $\left.\mathrm{n}^{\circ} 14\right)$ o el Jinete de Hornachuelos ( $\left.\mathrm{n}^{\circ} 15\right)$, aunque todavía mantienen elementos comunes con ejemplares del grupo IID, sobre todo el primero, que conserva las volutas características, presenta las piernas del jinete hacia atrás y ofrece el soporte calado, un detalle presente igualmente en el segundo ejemplar. Lo mismo cabe señalar del Jinete de Espejo-2 ( $\left.{ }^{\circ} 16\right)$, que puede considerarse el más tosco y degenerado del grupo.

A pesar de sus características específicas, estos jinetes se pueden relacionar con los representados en exvotos ibéricos de bronce, que ofrecen atributos bastante similares. Dada su semejanza, si falta el característico elemento de sustentación, en algunos casos puede ser difícil distinguir si se trata de un signum equitum o no, puesto que pueden proceder de los mismos talleres. Entre estos exvotos en forma de jinete, algunos se aproximan mucho por su estilo y disposición, mientras que otros no se confunden. Como ejemplos se puede señalar el Jinete MAN29328 (Álvarez-Ossorio 1941: 96, no 593; Prados 1992: $\mathrm{n}^{\circ}$ 426), el Jinete MAN-31843 (Álvarez-Ossorio 1941: 97, n 595; Prados 1992: n 422), el Jinete de El Salobral, conservado en el Museo del Louvre, AM 1306 (Paris 1904: 227-228, fig. 273; Nicolini 1969: 57 s., lám. I,1-3; 1977: no 21; Rouillard 1997: 126, n 191; AA.VV. 1998: $\mathrm{n}^{\circ} 28$ ), otro atribuido al Collado de los Jardines, Jaén, conservado en el Instituto Valencia de Don Juan (Moreno 2006: 504 s.), otro del Museo Marés (AA.VV. 2010: 146, $\left.n^{\circ} 190\right)$, otro de Sotheby's (2010: $\left.n^{\circ} 34\right)$, etc.

\section{DATACIÓN}

La seriación de estos "Jinetes de tipo La Bastida" permite precisar de modo tentativo su cronología a partir de su estilo y del armamento que lleva el jinete, ya que se desconoce el contexto arqueológico de más del $90 \%$ de las piezas (fig. 18).

El Grupo I ( $n^{\circ} 1$ y 2 ) ofrece rasgos arcaicos que ya no presentan las piezas posteriores, evidentes en el tratamiento de los ojos, y también los mechones del peinado deben considerarse de fines del s. VI o inicios del s. V a.C. como máximo, pues enlazan con los más antiguos bronces ibéricos del "grupo de los rizos largos", fechados hacia el 490-460 a.C. (Almagro-Gorbea et al. 2004: 228 s.).

El Grupo II se debe fechar a partir del segundo cuarto del s. V a.C. y ofrece un amplio desarrollo, pues debió perdurar bastante tiempo, hasta enlazar con los ejemplares más tardíos, como los del Grupo III. El Grupo II, por consiguiente, se fecha aproximadamente entre el 475 y el 300 a.C. En este grupo sólo el Jinete de La Bastida ( $\left.n^{\circ} 3\right)$ procede de un contexto arqueológico conocido. Se halló en este oppidum ibérico, construido a finales del s. V o inicios del IV a.C. y que fue abandonado a fines del s. IV a.C. (Bonet et al. 1997: 270 s.; Bonet y Vives-Ferrándiz 2011: 239 ss.). Esta cronología del poblado apuntaría a fechar el jinete en el s. IV a.C., pero el soporte estaba roto, posiblemente de antiguo, lo que indica que era una pieza anterior conservada por su simbolismo. Además, el rizo que ofrece el caballo en el cuello indica una cronología anterior, pues ya aparece en el caballo del Jinete Wace y también lo lleva el propio Jinete Ortiz en su peinado. Este rizo es característico de los bronces ibéricos identificados como "grupo de los rizos largos", al que pertenecen piezas de gran calidad, como el "guerrero sacrificando un carnero" del oppidum de Bujalamé, Jaén (Almagro-Gorbea y Lorrio 2011: 17 s.) o el personaje togado de la Real Academia de la Historia (Almagro-Gorbea et al. 2004: 228 s., $n^{\circ} 413$ ). Este rizo constituye un detalle estilístico muy característico de los mejores bronces y de alguna de las más bellas esculturas jonio-ibéricas del final del Arcaísmo (Almagro-Gorbea y Lorrio 2011: Apéndice I, 308), cuya cronología no es posterior al 475-460 a.C., pues el origen de este detalle se encuentra en caballos de bronce griegos arcaicos, como el Jinete de Armento, obra tarentina fechada c. 550 a.C. (Walters 1915: lám. I; Langlotz y Hirmer 1963: 63, no 26; Russo Tagliente 1998: 285-294).

Dentro de este marco cronológico, el Jinete de La Bastida debe datarse c. 475-450 a.C., datación que sirve de referencia para el Jinete Bagot, muy similar al de La Bastida, pero que ya no ofrece el característico rizo ondulado, aunque también lleva una larga machaira o falcata. Estos detalles permiten fecharlo poco después, en torno al 450 a.C. La calidad y coherencia estilística del Jinete de La Bastida ( $\left.n^{\circ} 3\right)$ y del Jinete Bagot ( $\left.n^{\circ} 4\right)$ confirman su datación en los momentos finales del Arcaísmo, pues, a pesar de su tendencia a formas estilizadas redondeadas, su gusto naturalista no exento de movimiento y realismo, lleno de fuerza y armonía, es característico del arcaísmo tardío, por lo que ambas figuras deben incluirse entre las mejores creaciones del estilo jonio-ibérico.

A partir de la segunda mitad del s. V a.C. se fecharían los restantes jinetes del Grupo II, ya más estilizados y de peor calidad. De la segunda mitad del s. V a.C. podrían ser los jinetes del Grupo IIA de La Carencia $\left(n^{\circ} 5\right)$, 
Martín Almagro-Gorbea, Alberto J. Lorrio Alvarado, Ana Vico Belmonte

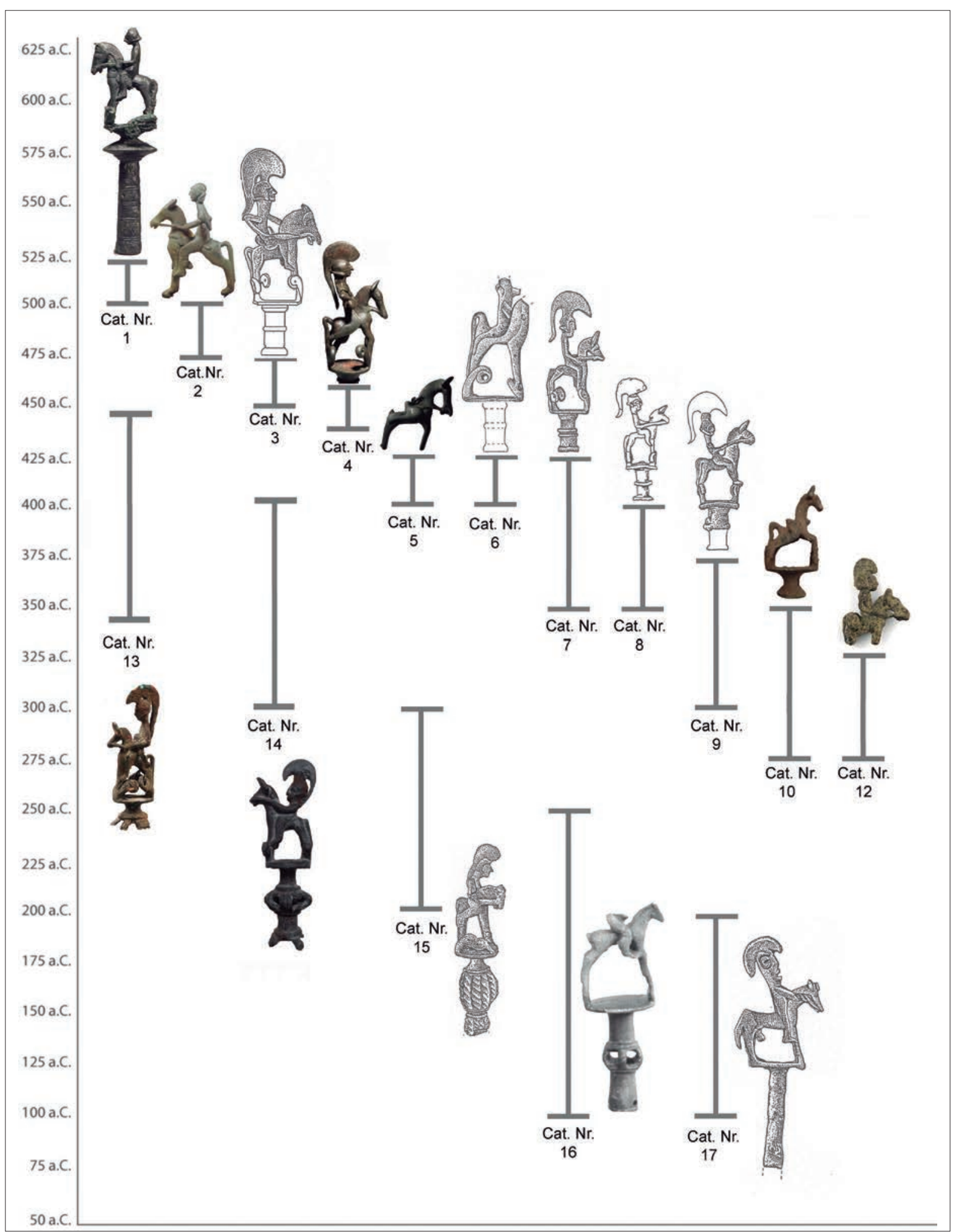

Fig. 18: Cuadro cronológico de los "Jinetes tipo La Bastida". 
Montilla ( $\mathrm{n}^{\circ}$ 6) y Chastel (Addendum), que parecen derivar de los anteriores, aunque más estilizados, si bien su rotura impide su datación precisa. En parte contemporáneos, pero ya posteriores, pueden ser los jinetes del Grupo IIB del Museo de Cuenca ( ${ }^{\circ} 7$ ), de Saint-Germain $\left(n^{\circ} 8\right)$ y, probablemente, de Espejo-1 ( $\left.n^{\circ} 9\right)$, que ya corresponderían al s. IV a.C., y aún más avanzados deben considerarse los jinetes del Grupo IIC del IVDJ $\left(\mathrm{n}^{\circ}\right.$ 10) y de la Colección Heiss ( $\left.{ }^{\circ} 11\right)$, cuya cronología podría alcanzar el s. III a.C. En consecuencia, estas piezas de los subgrupos IIB y IIC, de estilo cada vez más tosco, deben fecharse a lo largo del s. IV a.C. hasta inicios del s. III a.C. sin mayor precisión. El Jinete de Pinos Puente $\left(n^{\circ} 12\right)$, del grupo IID, por su estilo parece contemporáneo de las piezas más avanzadas del Grupo IIA, fechables en la segunda mitad del s. V a.C., mientras que el Jinete Segarra $\left(n^{\circ} 13\right)$ se aproxima a los jinetes del Grupo IIC, ya del s. IV a.C.

Los ejemplares del Grupo III ya deben datarse en el s. III hasta el II a.C. Lo forman los jinetes del Archivo Cabré ( $\left.{ }^{\circ} 14\right)$, de Hornachuelos ( $\left.n^{\circ} 15\right)$ y de Espejo-2 $\left(n^{\circ} 16\right)$, que deben considerarse los más modernos, como pudiera indicar su peor estilo y algunas características, entre otras la desaparición en los dos últimos de las volutas del soporte que ofrecen estos bronces ibéricos. Esta cronología avanzada la confirma el Jinete de Hornachuelos, cuyo contexto funerario, que constituye una referencia ante quem, se ha datado, sin certeza, entre mediados del s. II a.C. y finales del I a.C. (Rodríguez Díaz 2003). En consecuencia, este Grupo III puede fecharse en el s. III e incluso II a.C., prácticamente contemporáneo de los signa equitum celtibéricos (Almagro-Gorbea 1998; Lorrio 2010; Lorrio y Graells 2011-2012).

\section{FUNCIÓN Y SIGNIFICADO SOCIAL, RELIGIOSO E IDEOLÓGICO}

\section{EL ARMAMENTO DEL JINETE Y LOS ARREOS DEL CABALLO}

Estos jinetes están concebidos como guerreros heroizados, por lo que suelen ir desnudos y en su armamento destaca un llamativo casco con cimera, aunque se completa en un caso con una lanza, en siete casos con falcata, en tres con una caetra y al menos en otros seis casos el jinete aparece desarmado (fig. 17).
El casco es de forma redondeada, casi esférica, que deja la cara descubierta y ofrece un grueso reborde o guardanuca en su parte inferior. Por su forma se interpretaron como cascos de cuero (Kukahn 1954), sin nasal ni carrilleras, idea que el conocimiento de los cascos hispano-calcídicos obliga a rectificar (Graells et al. 2014), aunque el Jinete Segarra parece llevar un casco de tipo corintio avanzado o incluso calcídico (Pflug 1988: 87 s., 137 s.), por lo que pudiera tratarse de un casco hispano-calcídico, tipo cada vez mejor documentados en Hispania (Graells et al. 2014). El elemento más característico del casco es su gran penacho o cimera, que destaca sobre toda la figura y que prácticamente llevan todos los ejemplares. Este casco también lo llevan algunos raros exvotos de bronce de guerreros ibéricos procedentes del santuario del Collado de los Jardines, en Santa Elena, Jaén (Álvarez-Ossorio 1941: lám. 37, nº 29 y 31; Nicolini 1969: 120, fig. 1 y 2; AA.VV. 1998: $\left.325, n^{\circ} 281\right)$ y el guerrero poniéndose las grebas de la Colección Ortiz (1996: $\mathrm{n}^{\circ}$ 200), que no es seguro que sea un bronce ibérico, pero lo habitual es que los exvotos ibéricos lleven cascos sin cimera (Álvarez-Ossorio 1941: lám. 77-79, etc.).

También los guerreros del heroon de Porcuna, Jaén, usan cascos con cimera que parecen similares a los de estos jinetes (Negueruela 1990: fig. 4, 5, 18A, 18B, 19, lám. 1-9, 15-16, 42, 43A-B). Negueruela (ibid., 136 s.) observó que estos cascos de Porcuna no eran de tipo jonio, pues carecían de carrilleras móviles, por lo que los interpretó como un tipo local "jonio-ibérico", inspirado en los cascos jonios, por lo que estos cascos serían el precedente de los hispano-calcídicos (Graells et al. 2014). Los paralelos más próximos de los cascos de Porcuna se datan antes del 480 a.C. (Negueruela 1990: 137, lám. 43bis), fecha de las batallas de Salamina y de Himera, que tanta trascendencia tuvieron indirectamente en el mundo ibérico (Almagro-Gorbea 2009: 76; vid. infra). Esta cronología (Almagro-Gorbea 1996: 64 s.; 1999: 16), coincide con la que propuso hace años E. Kukahn (1954: 150) para el guerrero de La Bastida por motivos estilísticos, a pesar de fecharse el poblado entre finales del s. V o inicios del IV y fines del IV a.C. (vid. supra).

Otra arma característica es la falcata, pues era la habitual de los guerreros ibéricos (Quesada 1997: 100 s.). Falcata llevaban el Jinete Wace y los de la Colección, Ortiz, La Bastida, Bagot, probablemente los de La Carencia, Chastel y Montilla, el de Pinos Puente y quizás el del Instituto Valencia de Don Juan. El Jinete de la 
Colección Ortiz parece llevarla cruzada a la espalda, mientras que el Jinete de La Bastida es el único que empuña la falcata desenvainada, con su mano derecha. Los restantes casos la llevan en posición transversal al ir enganchada al cinturón, como era habitual en el mundo ibérico. Por el contrario, el Jinete Wace, el Jinete Bagot y los de Pinos Puente, Montilla y probablemente el Jinete del IVDJ llevan la falcata sujeta al cinturón, detalle que tiene paralelos en bronces ibéricos, tanto en jinetes (Álvarez-Ossorio 1941: nº 594-595, 599, 2426, etc.; Nicolini 1969: fig. 3, lám. IV y VI; Prados 1992: no 423; AA.VV. 1998: 328, $\mathrm{n}^{\circ}$ 295) como en infantes (AA.VV. 1998: no 280-282). Entre estas piezas destaca el Jinete Bagot, que empuña una gran falcata dispuesta en sentido transversal y de tamaño casi desproporcionado para resaltar su importancia, aunque pudiera tratarse de una machaira griega, como la procedente de Elche conservada en el Museo Arqueológico Nacional, datada a fines del s. VI o primera mitad del V a.C. (Quesada 1997: 129 s., fig. 70,3), cronología que coincide con la del Jinete Bagot (vid. supra). En esta pieza el artista ha recogido con realismo la tendencia curva del arma, la contera biesférica de la vaina (id.: 105 s.) y la empuñadura escotada propia de la machaira griega, aunque, a pesar de su estilización, también podría reflejar la característica empuñadura en forma de cabeza de águila de las más antiguas falcatas ibéricas, derivadas directamente de la machaira griega (id.: 100 s., fig. 43-44).

También el Jinete Wace lleva una lanza como única arma, a parte del casco, que sostiene con su mano derecha a mitad del astil en posición inclinada, pues es una lanza de punta corta y no de gran longitud, como evidencia su tamaño, aunque se podría usar como estoque o lanzada a distancia desde el caballo. La lanza aparece en la Edad del Bronce y pasó a ser el símbolo del guerrero, más incluso que la espada (Almagro-Gorbea 2016), por lo que era el arma más popular y más usada entre los íberos (Quesada 1997: 343 s.). Sin embargo, no son frecuentes los exvotos ibéricos de jinetes con lanza, aunque haya piezas destacadas, como el Jinete del Collado Jardines conservado en el Museo Arqueológico Nacional que lleva la lanza de la misma forma (Álvarez-Ossorio 1941: $\mathrm{n}^{\circ}$ 593). Los mejores paralelos, por su contexto cronológico y cultural, son algunas esculturas del heroon de Porcuna, en los que la lanza es el arma del héroe protagonista (Negueruela 1990: fig. 9-13, lám. 18 a 22), pero jinetes con lanza aparecen representados en estelas y cerámicas posteriores (Quesada
1997: 411 s.), sin olvidar las conocidas monedas ibéricas del jinete lancero, en las que es el arma que lo caracteriza (Almagro-Gorbea 1995).

La caetra resulta poco frecuente en estos jinetes (Quesada 1997: 489 s., 542 s.), pues sólo aparece en tres ocasiones. El Jinete Ortiz la lleva a la espalda, como tres exvotos de jinetes del Santuario de Despeñaperros (Álvarez-Ossorio 1941: nº 594, 596 y 599) y otro muy tosco del Instituto Valencia de Don Juan (Nicolini 1969: lám. 6). El Jinete de La Bastida la empuña en el brazo izquierdo junto a la brida, igual que parece hacerlo el Jinete del Archivo Cabré, aunque su mal estado de conservación deja el detalle confuso. Un exvoto ibérico de jinete con caetra igualmente en el brazo izquierdo junto a la brida procede de El Salobral (Nicolini 1977: $\mathrm{n}^{\circ}$ 21; AA.VV. 1998: $\mathrm{n}^{\circ}$ 28; Rouillard 1997: $126, \mathrm{n}^{\circ} 191$ ), cuyo casco permite datarlo hacia el s. V a.C., y de la misma forma coge la caetra un jinete del santuario de Nuestra Señora de la Luz (Nicolini 1977: $\mathrm{n}^{\circ}$ 77) y otro del Santuario de Despeñaperros (Álvarez-Ossorio 1941: $n^{\circ}$ 596), pero cabe citar otros ejemplos no tan próximos (Álvarez-Ossorio 1941: ${ }^{\circ}$ 598; Nicolini 1969: lám. 2 y 5), aparentemente ya más tardíos y de peor estilo.

El caballo que montan estos jinetes suele estar en disposición estática, aunque con su cabeza ligeramente inclinada hacia el lado izquierdo, quizás para darle más realismo. Los ejemplares del Grupo I son de forma más graciosa y con tendencia a un naturalismo esquematizado, pues no ofrecen el movimiento del arcaísmo final. Los caballos del Grupo IIA resultan más estilizados y sobrios en su modelado y aún mayor estilización de las formas curvilíneas ofrecen los caballos de La Carencia, Colección Chastel y de Montilla. Los caballos del grupo IIB son más secos y menos expresivos y de ellos derivan los caballos del Jinete del IVDJ y, en especial, del Grupo III, del Archivo Cabré, de Hornachuelos y de Espejo-2, de formas aún más estilizadas, lo que les diferencia del Grupo II y que son obra de artesanos de poca habilidad artística, sobre todo en el caso del ejemplar andaluz.

En la mayoría de las piezas el jinete monta el caballo a pelo, sólo con las bridas, salvo los jinetes del Grupo I, que llevan pechopetral y una piel como silla o ephippium (Fernández Nieto 2018), como algunos exvotos ibéricos (Nicolini 1969: lám. V y VI; AA.VV. 1998: nº 294 y 295). Por ello, el caballo sólo lleva las bridas y un alto tocado en forma de creciente o abanico, que adorna la 
frente de casi todos los caballos de estos "Jinetes tipo La Bastida". La excepción la forman los caballos del grupo I y el Jinete de la Bastida del grupo IIA, lo que confirma su mayor antigüedad, y también carecen de este adorno las piezas más tardías, como los jinetes del Archivo Cabré y de Espejo-2.

Este adorno semicircular resulta raro entre los exvotos ibéricos de jinete, aunque lo llevan el citado Jinete de El Salobral, Albacete (Nicolini 1969: 59, lám. I,3), dos ejemplares del santuario del Collado de los Jardines, Jaén (Alvárez-Ossorio 1941: 97-98, nº 598, M.A.N. 29332, y 99, nº 606, M.A.N. 29329; Nicolini 1969: lám. V y VI), y el conocido caballo de bronce de Cancho Roano, Badajoz (Celestino y Zulueta 2003: 52-55, fig. 16.1, lám. X.3-4), que ha perdido el jinete, por lo que pudo ser una figura de jinete heroizado, cuyo prototipo orientalizante pudiera verse en el jinete del sello de un anillo de oro del tesoro de Aliseda, Cáceres (AlmagroGorbea 1977: lám. 30,2 y 4).

Este adorno del caballo debe considerarse de origen oriental, pues su origen puede verse en los penachos emplumados de los caballos de los carros de guerra egipcios, como los representados en el cofre polícromo o en el espantamoscas de oro (fig. 19,A ) de la tumba de Tutankamón (Desroches-Noblecout 1963: lám. 17 y 20). De Egipto debieron pasar a los carros de guerra regios neohititas (fig. 19,B) (Akurgal 1969: fig. 86; Orthmann 1971: lám. 24 ,a, c y f; Bittel 1976: fig. 291) y a los de Fenicia y Chipre, como evidencian los carros de la tumba real de Salamina 79 (Karageorghis 1968: lám. 123). También llevan un penacho semicircular los caballos asirios (fig. 19,C) (Layard 1867: 234 s.; Barnett 1961) y alguno persa (Girshman 1964: 261, fig. 315; Curtis, y Tallis, eds. 2005: $\mathrm{n}^{\circ}$ 409). A través de Persia y Anatolia la idea pudo pasar al mundo griego jonio (Donaghy 2014: fig. 18,2-3), y desde éste o desde el mundo fenicio colonial llegó al mundo ibérico.

\section{PARALELOS Y FUNCIÓN DE LOS “JINETES DE TIPO LA BASTIDA"}

Estos "Jinetes tipo La Bastida" constituían el extremo de un vástago de enmangue por ser el elemento esencial de estandartes o signa equitum ibéricos (Lorrio y Almagro-Gorbea 2004-2005; Almagro-Gorbea y Lorrio 2007), lo que permite diferenciarlos de los exvotos depositados en santuarios.

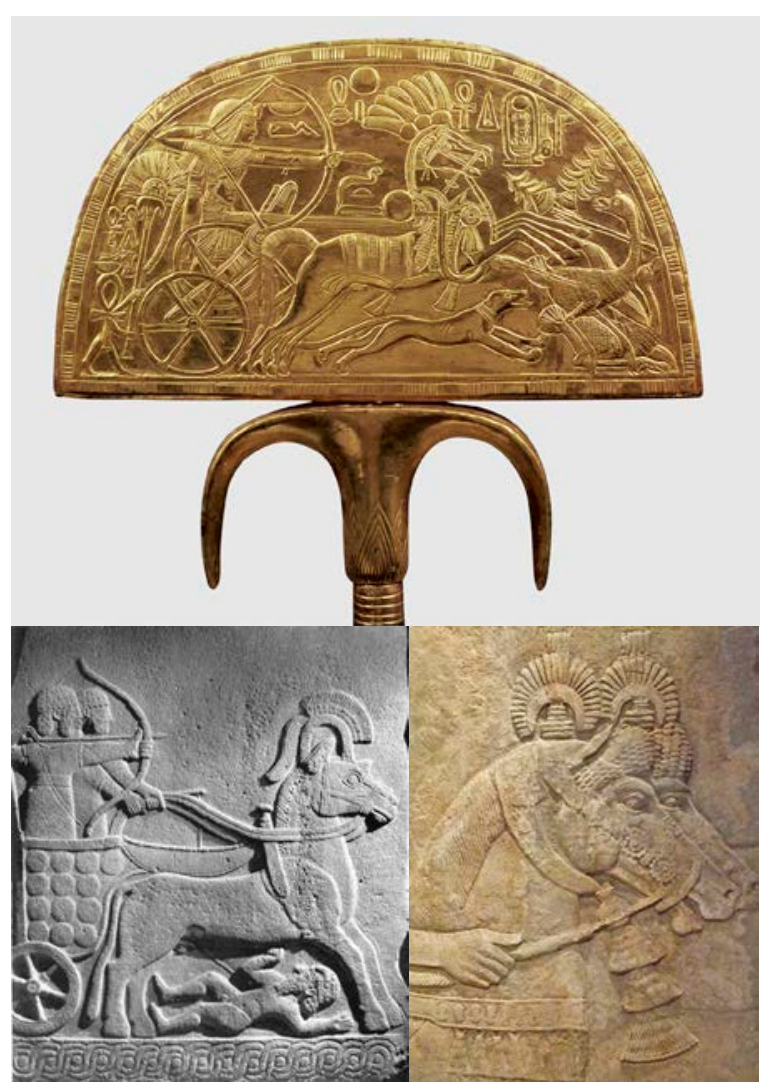

Fig. 19: A, Abanico de oro de la tumba de Tutankamon (Foto National Geographic). B, Carro neohitita de Carquemish (Bittel 1976: fig. 291). C, Caballos asirios (Foto Pinterest).

El uso de signa militaria, como parecen designarlos las fuentes históricas, era habitual entre iberos y celtíberos (Taracena 1954: 271). Tito Livio narra cómo C. Cornelio Cetheco capturó el 200 a.C. 78 signa militaria (Liv. 31,49,7). El 181 a.C., en Contrebia Carbica, se capturaron "62 enseñas militares... de los celtíberos" (Liv. 40,33: signa militaría sexaginta duo... Celtiberiorum). M. Fulvio, el 180 a.C., capturó 72 insignias (Liv. 40,11) y el 211 a.C. también se indica cómo alzar estas insignias era la señal de partida (Liv. 25,33: signis repente sublatis Celtiberia abeunt) y por ellas se podía distinguir a cada pueblo, como cuando el 195 a.C. los Suesetanos reconocieron las arma signaque Lacetani (Liv. 34,20). También se recoge la noticia de que la caballería de César capturó a los Saguntinos sus signa (b.H. 10,1: ...Argentius ex Italia cum equitatu venit. Is signa Saguntinorum rettulit quinque, quae ab oppidanis acepit). 
Los signa equitum celtibéricos han atraído hace años el interés de la investigación (Almagro-Gorbea 1998; Pastor Eixarch 1998; Almagro-Gorbea y Torres 1999: 96 s.; Lorrio 2005: 198; 2010; Lorrio y Graells 2011-2012). Sin embargo, los signa equitum celtibéricos son diferentes de los ibéricos y en su mayoría posteriores, pues los ejemplares aparecidos en la necrópolis de Numancia se fechan en el s. II a.C., antes de que P. Cornelio Escipión conquistase y arrasara la ciudad el 133 a.C. (Jimeno et al. 2004: 69), por lo que su cronología es contemporánea de los jinetes ibéricos más tardíos del Grupo III. En Numancia han aparecido diversos signa equitum (Schulten 1931: 271, lám. 44B), uno en la ciudad ensartado en un astil de madera de 1,50 $\mathrm{m}$ de largo con un regatón de bronce en su otro extremo (Mélida et al. 1924: 30, lám. 8,1) y varios en la necrópolis, como los de la tumba 38 , que proporcionó dos ejemplares (Jimeno et al. 2004: 164, fig. 121 y 122c, lám. 13,12). Estas piezas ofrecen un enmangue tubular y un remate formado por dos prótomos de caballo contrapuestos decorados con círculos solares (fig. 20, A), bajo cuyos hocicos aparecen sendas cabezas humanas esquemáticas. Las piezas halladas en la necrópolis miden entre 10 y $12 \mathrm{~cm}$ de alto incluido el jinete (Jimeno et al. 2004: 164), por lo que su dimensión es comparable a la de sus paralelos ibéricos.
Estas piezas celtibéricas se han considerado cetros, insignias o pequeños estandartes (Schulten 1931: 271; Mélida et al. 1924: 30; Pastor Eixarch 1998; Lorrio 2005: 198; Lorrio y Graells 2011-2012: 214-215), "báculos de distinción" (Jimeno et al. 2004: 170) y, con más precisión, signa equitum (Almagro-Gorbea y Torres 1999: 97; Almagro-Gorbea 1998: 103 s.; Lorrio 2010). En cualquier caso, la singularidad de este elemento queda fuera de discusión ante su relación con el бxíлt@ov, un elemento simbólico de intermediación entre la divinidad y los mortales y, por lo tanto, detentor del mando y del uso de la palabra (Cordano 2007), aunque con el paso del tiempo transformaría su significado original regio por otras funciones igualmente relevantes (Melotti 2001; 2003). Numerosas fuentes greco-latinas citan el cetro o bastón de mando como transmisor de un estatus particular a sus poseedores, especialmente cuando lo relacionan con un heraldo en una estructura social y organizativa más articulada que su mera posesión, pues el cetro de mando era de origen divino y propio del basiléus (Melotti 2003: 21), según las fuentes literarias (Hom. Il. II,100-108; Paus, 9,40,11-12; Xen. Mem. 3,9,10; Dio.Hal. 3,62,1), a pesar de la iconografía ecuestre de estos ejemplares.

La identidad formal de los signa equitum con las fíbulas de jinete y de caballito celtibéricas, fabricadas en los mismos talleres y que tienen el mismo significado

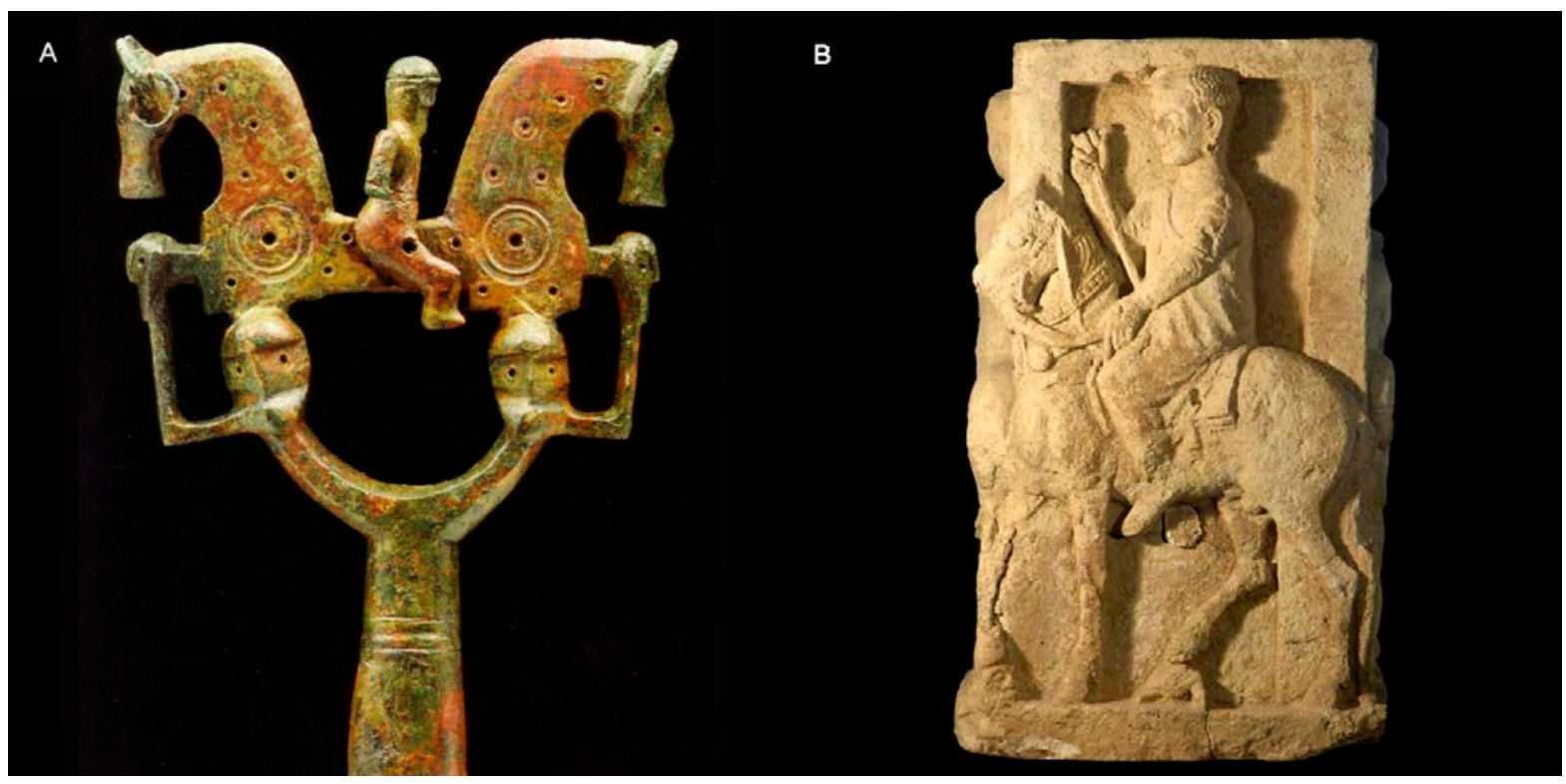

Fig. 20: A, Signum equitum celtibérico de Numancia (Jimeno et al. 2004: fig. 121). B, Estandarte de Coimbra del Barranco Ancho, Jumilla (García Cano 1997: lám. 49). 


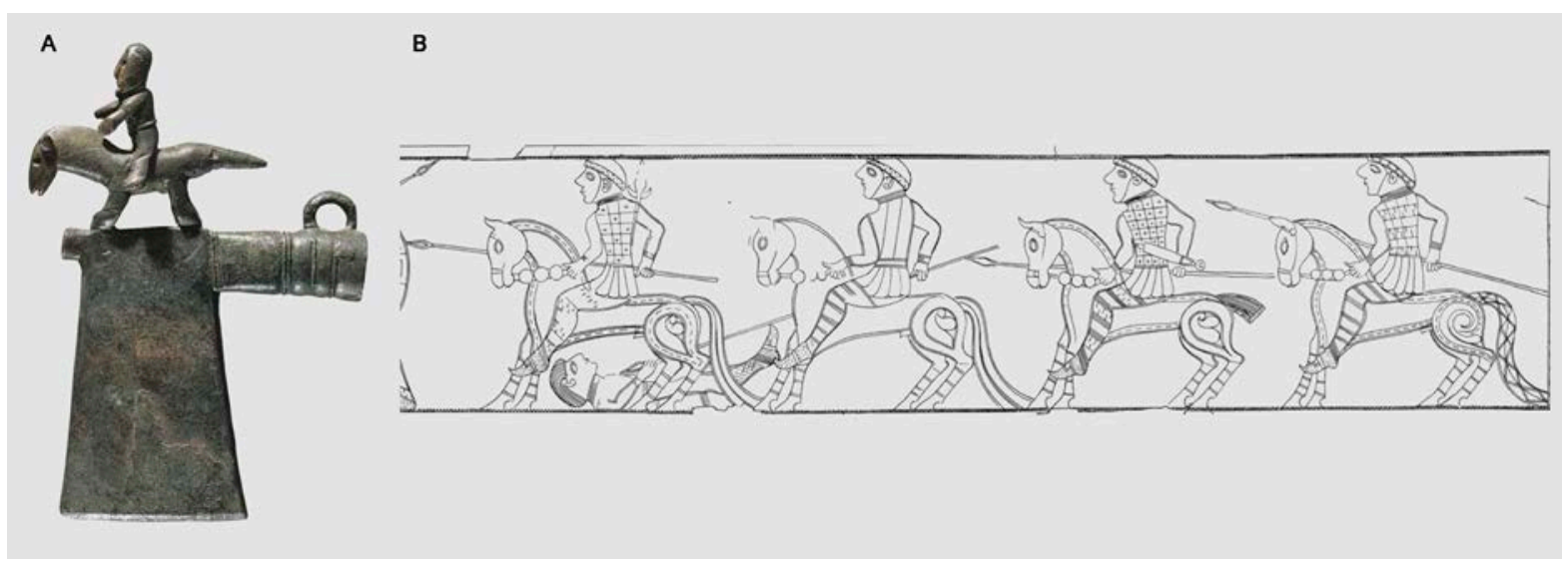

Fig. 21: A, Insignia en forma de hacha con un jinete de la tumba 641 de la necrópolis de Hallstatt (Kruta 1992: fig. 168). B, Espada de la necrópolis de Hallstatt, con una turma dirigida por un jinete con un estandarte al hombro (Kromer 1959).

(Almagro-Gorbea y Torres 1999: 97), indica que unos y otras eran símbolos de los equites, la clase dirigente de los oppida (Almagro-Gorbea 1999), hecho que corrobora la importancia que tuvo la caballería entre los celtíberos (Taracena 1954: 272 s.; Almagro-Gorbea y Torres 1999: 96 s., 109), también en el aspecto social e ideológico, como evidencian las elites ecuestres celtibéricas (Almagro-Gorbea y Torres 1999: 96 s., 109; Almagro-Gorbea 1999; 2005a). Estos estandartes o signa equitum, eran símbolos de máximo prestigio y poder social, con un claro significado sacro y ritual y sobre ellos se debería hacer la coniuratio o juramento militar, como hacían los Samnitas y supuestamente también los galos (Brunaux y Lambot 1987: 40), rito que también debían practicar iberos y celtíberos.

Estos signa equitum eran símbolos de poder de los jefes de la caballería ibérica y celtibérica (Almagro-Gorbea 1998: 103 s.; Almagro-Gorbea y Torres 1999: 97; Almagro-Gorbea 1998: 103 s.; Almagro-Gorbea y Lorrio 2010), a los que alude el antropónimo galo Eporedorix, que significa jefe o "rey de la caballería" (Evans 1967: 90 s.), título atestiguado repetidamente (b.G. 7,38,2, 39,3, 40,5, 67,7; CIL 13,2805 y 27281), como ya señaló Holder (1896: 1452,24 s., 1453,29 s.). Pero el mismo significado tenía el nombre griego Hipocrates y el etrusco Macstrna, con el que se denomina en fuentes etruscas a Servio Tulio, pues equivalía al Magister Equitum en Roma (De Simone 2002). Este cargo era originario de la monarquía (De Francisci 1959: 610 s.) y es el precedente del magister equitum de la República (Mommsen 1893: 204), que posteriormente pasó a ser el tribunus equitum (b.G. 7,67,7). El origen de estos cargos y de sus insignias se remonta al inicio de la caballería, ya en el Hallstatt C, como evidencian las hachas simbólicas con un caballo o jinete (fig. 21, A), interpretadas como símbolos de lictores curiati ecuestres que acompañarían al rix celta (Alföldi 1974: fig. 3), como documenta la representación de una turma o escuadrón de jinetes dirigidos por un Eporedorix con un signum equitum sobre el hombro como símbolo de mando (fig. 21, B) en la vaina de espada de la tumba 994 de la necrópolis de Hallstatt (Frey 1991: 131; Sievers 1993: fig. 36).

Esta rica información sobre la función que tenían los "Jinetes tipo La Bastida" queda confirmada por el vástago de lámina de bronce para revestir el astil de madera de más de $41 \mathrm{~cm}$ de alto muy probablemente aparecido con el Jinete del Museo de Cuenca, mientras que el Jinete de Espejo-2 ofrece un vástago de bronce que se insertaría directamente en el astil. Este vástago metálico ayuda a conocer la longitud de los signa equitum ibéricos. El astil del signum equitum hallado en Numancia medía c. 1,50 m de largo con su regatón de bronce (Mélida et al. 1924: 30, lám. 8,1). Sin embargo, el vástago del Jinete del Museo de Cuenca (fig. 7, B), que pudo alcanzar los $50 \mathrm{~cm}$, tiene una moldura de bronce fundido, bien conservada, que mide 3,45/3,50 cm de diámetro. Esta precisa dimensión pudiera corresponder a $1 / 2$ palmo de $7 \mathrm{~cm}$ y a un pie ibérico de c. $28 \mathrm{~cm}$ (4 palmos = 1 pie), documentado en monumentos escultóricos del SE (Izquierdo 2000: 398 s.; AlmagroGorbea et al.2016: 73), que corresponde a una unidad de medida probablemente de origen focense, usada por diversas regiones del Mediterráneo Occidental, medida de la que derivaría el pie de $c .27,8 \mathrm{~cm}$, que equivale a $1 / 3 \mathrm{de}$ la vara castellana de $83 / 84 \mathrm{~cm}$ (Almagro-Gorbea 2005). 
Según esta hipótesis, la longitud de estos cetros se puede calcular en $c .56 \mathrm{~cm}$ o 2 pies ibéricos de $c .28 \mathrm{~cm}$. Una dimensión parecida puede calcularse para el cetro o estandarte representado en uno de los relieves del cipo funerario de la necrópolis de Coimbra del Barranco Ancho, en Jumilla, Murcia (fig. 20,B), que formaba parte de un pilar-estela de mediados del s. IV a.C., relacionado con la sepultura 70, la más rica de la "Necrópolis del Poblado" (García Cano 1997: 265 s., fig. 38b, lám. 49 y 55), lo que ratifica que estos cetros eran elementos simbólicos de la cúspide social, probablemente de carácter regio. El relieve representa a un jinete de edad avanzada que lleva en su mano derecha y apoyado en su cadera un "bastón, báculo o cetro terminado en T" con sus remates curvados hacia arriba (Muñoz 1983; 1987: 236), aunque su tamaño total no se aprecia al quedar por detrás del cuerpo de jinete. La forma del "cetro" de Jumilla recuerda los modelos más sencillos de signa con un enmangue tubular finalizado en una horquilla simple o rematada en sendas volutas o en cabezas humanas (Lorrio 2010: fig. 1), que han aparecido en diferentes contextos peninsulares (Lorrio 2005: 186 y 196, fig. 69,B; Manso 2005: 130 s.; Lorrio y Graells 2011-2012). Sus mejores paralelos proceden de la necrópolis de Numancia, donde se han interpretado como remates de báculos (Jimeno et al. 2004: 163 y 167, fig. 121 y 122, a-b y d), pudiendo citar la insignia que lleva el jinete de Seteisken (fig. 22, A: Aureo 27.2.2002, que agradecemos a P. P. Ripollés).

También signa militaria aparecen representados en monumentos honoríficos galo-romanos, como el Arco de Orange (Amy 1962), y en monedas galas, que muestran jinetes portando estandartes acabados en jabalí, en ave, etc. (Forrer 1908: I, 46-47, fig. 88, II, 25; Allen 1980:
139; Blanchet (1905: $\mathrm{n}^{\circ} 780,1947,3737-9,4367-9$; 7976-78, 4336, 4483-4494, 5026-35, 5037-48, 6388-9, etc.), y los denarios de C. Coelius Caldus, gobernador de la Hispania Citerior y triumviro monetal del 51 a.C., representan insignias galas que aludirían a su victoria sobre el pueblo celto-ligur de los Salluvii de la zona de Marsella (Crawford 1974: 459, n 437,2), como también la ceca de tipo hispánico de Kurukuruatin, del Rosellón (fig. 22, B) (Villaronga 1979: 309, $\mathrm{n}^{\circ}$ 1169), ofrece un estandarte acabado en jabalí (Forrer 1908: 25; Untermann 1975: 222, A30) e incluso algunos de estos estandartes ofrecen una estructura simétrica como las piezas de Numancia con sendos prótomos zoomorfos (Lengyel 1969: 158, $\mathrm{n}^{\circ}$ 23; Lorrio y Graells 2011-2012: 214).

Sin embargo, los estandartes hispanos son más pequeños y sobrios que los galos, pues parecen mantener su carácter arcaico originario, no alejado de los signa equitum del Hallstatt (fig. 21, A y B), decorados con caballos y jinetes (Almagro-Gorbea y Torres 1999: lám. 33) y, además, son de pequeño tamaño, lo que los diferencia de los estandartes y los aproxima a los cetros antiguos (Weidig 2014: I, 186 s., 194 s.; Manca y Weidig 2014; Weidig y Bruni 2017). Otros paralelos pueden considerarse el pequeño estandarte o cetro de forma simétrica que llevan algunos jinetes hispánicos (fig. 22), como el de una emisión de la primera mitad del s. II a.C. de la ceca de Seteisken, relacionada con los Sedetanos del valle del Ebro, que recuerda los signa celtibéricos (Untermann 1975: 214, 1. A25,1; Villaronga 1979: 133, $\mathrm{n}^{\circ} 303$; 1994: 219), otro de Sekaisa con un jinete con insignia en ristre (Villaronga 1994: 231 s., n 1-2) y otra de esa ceca, más dudosa, de jinete con "cetro al hombro" que parece acabar en un ave (fig. 22, C) (id.: 232, no 3-8, etc.).

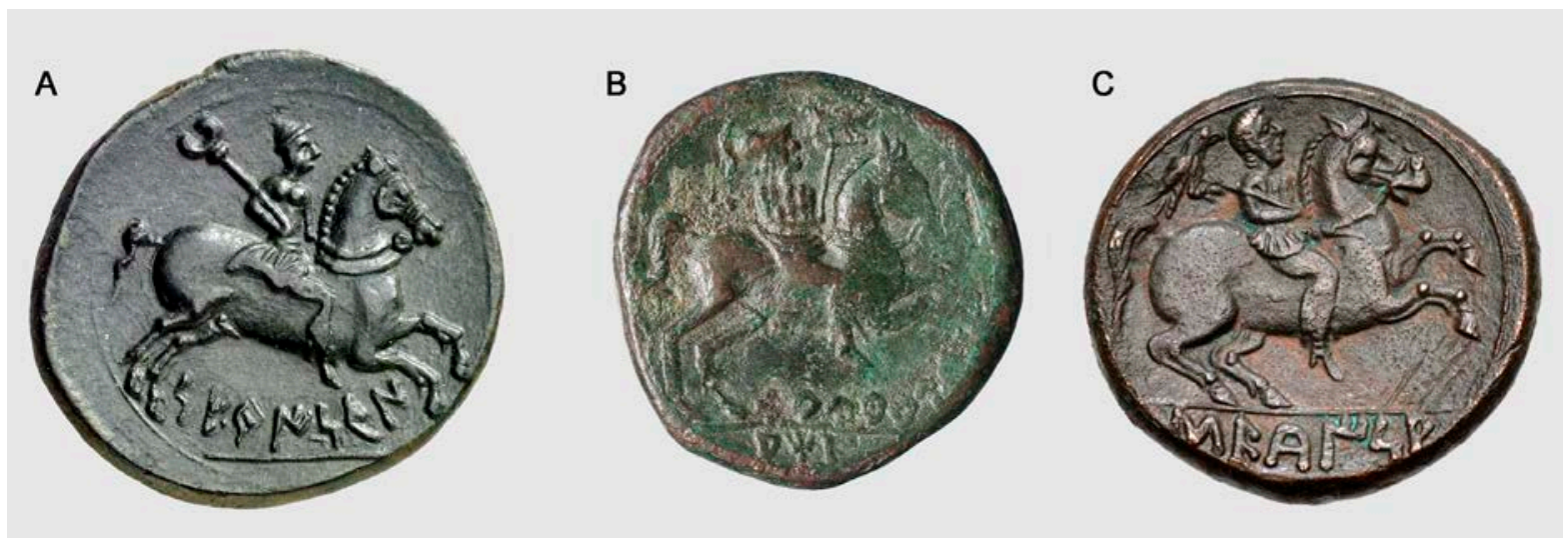

Fig. 22: A, B, C, Jinetes con estandartes en monedas de tipo hispánico (Fotos Aureo 27.2.2002; BM y CNG 18.5.2011). 
Por su cronología y contexto ritual, todavía es más interesante una referencia recogida por Timeo y transmitida por Dionisio de Halicarnaso (FGH 566 F 59; = DH. $1,67,4)$ sobre los Penates de Lanuvium, traídos de Troya por Eneas (Dubourdieu 1989: 171 s., 264 s.). Según contaron los habitantes de Lavinio a Timeo, historiador de gran solvencia (Baron 2013: 47), estos Penates eran unos

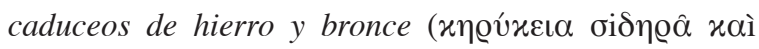
$\chi \alpha \lambda x \hat{\alpha}$, en DH. $1,67,4)$. Aunque no se conserva ninguna representación de estas piezas, salvo la noticia de Timeo, su forma de caduceo permite relacionarlos con estos signa equitum rematados por un jinete, pues, además, se asimilaron a los Dioscuros (d'Anna 1982; Stehle 1991), lo que permitiría suponer que estuvieran rematados por jinetes que representaran dichas divinidades ecuestres, hecho que aproximaría los Penates de Lavinium, formal y ritualmente, a estos signa equitum ibéricos.

\section{EL JINETE COMO REPRESENTACIÓN DEL HÉROE FUNDADOR Y PATRONO PROTECTOR}

Los "Jinetes de tipo La Bastida" tenían un claro significado social e ideológico, que explica por qué se extendieron por amplios territorios ibéricos durante siglos. La clave del significado religioso e ideológico de estos signa equitum es, por una parte, el jinete, un guerrero desnudo que aparece armado o no, pero que siempre lleva un casco de alta cimera, y, por otra, el soporte de volutas que lo sustenta, cuyo simbolismo da la clave para explicar el significado del jinete.

Como es bien sabido, el caballo siempre ha sido un símbolo para las elites guerreras y pronto se asoció a la heroización. El caballo llegó con el carro, pero la equitación se generaliza por Europa tras las penetraciones cimerias desde las estepas a partir del Ha B-2 (Chochorowski 1993) y reforzó el carácter aristocrático de las elites guerreras del Hallstatt, que adoptaron enseñas como las hachas con un caballo o jinete (fig. 21, A), interpretadas como símbolos de los lictores curiati ecuestres que acompañaban al rix (Alföldi 1974: fig. 3).

Un proceso similar ofrece Grecia, donde el caballo era un claro elemento aristocrático, pues ya en la Ilíada hippeús significa "jinete", con un sentido de elite que mantuvo toda la época arcaica. Los hippeîs no eran sólo guerreros a caballo, sino un rango militar y civil expresado por la posesión del caballo, pues constituían una aristocracia de caballeros que dominaba la vida política (Helbig
1902; Alföldi 1965). Desde Oriente, la equitación se introdujo en el s. VIII a.C. en Chipre (Crouwel y TattonBrown 1988) y en Grecia (Alföldi 1965: 17 s.; Donder 1980; Ducrey 1985: 96 s.) y en el s. VII a.C. sustituye al carro como símbolo de nobleza (Ducrey 1985: 35), pasa a formar parte de la educación juvenil de las elites y se incorpora a procesiones y cultos y a las Olimpiadas el 648 a.C. (Anderson 1961). Tras la reforma de Solón a inicios del s. VI a.C., los hippeîs acceden a las magistraturas más altas del estado, como el arcontado (Arist. Constit. Aten, 7,4, s.; Metzger y van Berchem 1967: 157) y el hypparcos llegó a ser la autoridad máxima en Cícico, Mileto y Cumas, donde perduró hasta el 524 a.C. (Alföldi 1965: 16 s.). El mismo contexto sociopolítico e ideológico del caballero se extendió por Italia (Lubtchansky 2005) y por diversas culturas mediterráneas, entre otras, por la Hispania prerromana, como evidencian los "Jinetes de tipo La Bastida".

El carácter aristocrático del caballo en Grecia se refleja en la religión y en el arte (Woysch-Méautis 1982: 36), como muestra la iconografía de bronces, esculturas y vasos pintados del Periodo Geométrico y Arcaico, y en tiempos de Pisístrato las esculturas de jinetes áticos se convirtieron en el símbolo aristocrático más característico (Vogt 1991; Eaverly 1995), lo que da la clave para entender el significado social de las esculturas ecuestres ibéricas y de los "Jinetes de tipo La Bastida". Estas esculturas ecuestres griegas fueron el modelo de las primeras esculturas de jinetes ibéricos que coronaban monumentos funerarios, como las dos de Los Villares, una fechable a fines del s. VI y otra a inicios del V a.C. (Blánquez 1995: 76; Blánquez y Sanz Gamo 2010) y la algo más tardía de Casas de Juan Núñez (Blech et al. 2001: lám. 218), todas ellas en Albacete. Junto a estos jinetes ibéricos, el mejor paralelo iconográfico de los "Bronces de tipo La Bastida" es el disco de terracota de Douimès, en Cartago, de fines del s. VI o inicios del V a.C. (Fantar 1970: 19 s., lám. 15). Este disco ofrece un jinete púnico con un casco con cimera abierto por delante, como el de los "Jinetes tipo La Bastida", armado con una lanza y también con un pequeño escudo redondo. Completa la iconografía una flor con volutas dispuesta delante del caballo, un perro que corre debajo y un creciente lunar con disco solar detrás (fig. 23, A). Esta iconografía se relaciona con creencias en la heroización ecuestre extendidas por el Mediterráneo entre las elites del final del Arcaísmo, por lo que resulta muy próxima a la de los "Jinetes de tipo La Bastida". 
El casco con cimera de este guerrero púnico se puede relacionar con el casco corintio de la "Tumba del Guerrero" de Málaga (García González et al. 2018). Este casco, datado c. 575-550 a.C., apareció depositado como sema sobre la tumba (Torelli 2018: 22-23), por lo que se ha atribuido a un jefe guerrero, probablemente un mercenario, ya que esa tumba ofrece una estructura extraña a las costumbres funerarias locales (Martín Ruiz 2009). Su cronología permite suponer que el posesor del casco fuera un hegemón mercenario defensor de Malaka en la segundo tercio del s. VI a.C., periodo que corresponde a destrucciones y obras de fortificación en yacimientos de las costas meridionales de Hispania, seguramente relacionadas con ataques y acciones de piratería de los focenses basados en la eficacia de sus pentekonteres. Estas acciones guerreras hasta ahora han sido poco valoradas, pues las fuentes escritas no ofrecen detalles, aunque parecen relacionarse con la destrucción y abandono de yacimientos fenicios, como La Fonteta y Toscanos, y el amurallamiento de otros, como el Cerro Alarcón o la misma Malaka, en ocasiones tras buscar un emplazamiento más defensivo (Almagro-Gorbea y Guerrero 2009: 352 s.).

El casco corintio de Malaka, como los cascos que llevan los guerreros del heroon de Porcuna (vid. supra), confirma que eran un símbolo de poder del hegemón, caudillo o jefe guerrero en el Mediterráneo Occidental al final del arcaísmo, razón por la que lo llevan todas estas figuras de jinete. Sin embargo, a partir de la segunda mitad del s. V a.C., este casco jonio-ibérico con cimera resultaría anacrónico, aunque se mantuvo por su simbolismo hasta el final de estos signa equitum ibéricos en el s. III a.C., perduración que indica que este jinete con casco no representaba a un jinete real de la época, sino una figura de la historia mítica, que hay que interpretar como la imagen del "héroe fundador" de la estirpe de quien lo portaba (vid. infra).

La misma idea indican los dos pares de volutas sobre las que se apoya el jinete, pues también son un elemento característico que sólo falta en los últimos ejemplares, ya degenerados, del Grupo III. Estas dobles volutas que sustentan al jinete, por su forma, función y significado, representan sendos "capiteles protoeólicos". El "capitel protoeólico" procede de Oriente (Betancourt 1977; Shiloh 1979; Akurgal 2000: 53 s.; Almagro-Gorbea y Torres 2010: 258 s.) y simbolizaba el Árbol de la Vida, representado en marfiles, bronces, cerámicas, etc. (Dantine 1938; Parrot et al. 1975: fig. 100, etc.), pues era la representación de la diosa Asherat-Astart, por lo que era un símbolo apotropaico y de fecundidad muy popular
(Merhav 1980). De Oriente pasó a Chipre (Betancourt 1977; Shiloh 1979; Akurgal 2000: 53 s.), llegó a la Jonia Arcaica (Akurgal 1969: 226 s.; 2000: 53 s.) y también a Occidente, como evidencian algunos anillos áureos del tesoro de Aliseda (Almagro-Gorbea 1977: lám. 31-32) y el capitel protoeólico de Cádiz de $c .600$ a.C. (Blázquez 1975: 167 s., lám. 63; Almagro-Gorbea y Torres 2010: 250 s., fig. 211), cuyo pequeño tamaño indica que sería el soporte de alguna figura o exvoto del santuario gaditano, por lo que puede considerarse un precedente del soporte de volutas que sustenta a estas figuritas de bronce. También capiteles de volutas sostenían las figuras donadas como exvoto en santuarios griegos, como la conocida esfinge de Naxos, fechada hacia el 560 a.C. (Amandry 1953: $1 \mathrm{~s}$., lám. 14). Este capitel protoeólico, asimilado por artistas jonios dentro del proceso "orientalizante" (Akurgal 1969: 226 s.; 2000: 53 s.), simplificado y racionalizado, es el origen del capitel jónico. La amplia difusión de este capitel dificulta saber si las volutas que sostienen a estos pequeños bronces proceden del ámbito jonio, aunque más bien parecen relacionarse con estímulos fenicios, como las volutas protoeólicas del heroon de Porcuna, datadas a inicios del s. V a.C. (Negueruela 1990: 275, fig. 36, lám. 52), influjo que también reflejan las golas (id., 273 s., fig. 3235, lám. 51), similares a las del monumento de Pozo Moro (Almagro-Gorbea 1983) y de influjo fenicio como éstas.

También el "Guerrero sacrificando un carnero" de Bujalamé, Jaén (Almagro-Gorbea y Lorrio 2011: 17 s.) se sustenta sobre dobles volutas contrapuestas, como los "Jinetes tipo La Bastida", por lo que bien pudiera ser un estandarte regio, ya que su estilo jonio-ibérico es muy semejante $\mathrm{e}$, incluso, pudiera interpretarse como un penate comparable a los aludidos por Timeo en Lavinium (vid. supra), puesto que estos cetros sacros podían ser objeto de culto (Melotti 2003: 24 s.). Es una obra maestra entre los pequeños bronces ibéricos, datada hacia el 490 a.C. como indican los rizos ondulados de su peinado, característicos de un taller jonio-ibérico creador de las mejores piezas de toréutica ibérica documentado en el Collado de los Jardines, Jaén, hacia el 490-450 a.C. (Almagro-Gorbea et al. 2004: 229-230; Almagro-Gorbea y Lorrio 2011: 302 , Apéndice 2).

El motivo oriental de las dobles volutas llegó a Occidente a través de los fenicios. Su uso como soporte indicaba que el jinete puesto encima estaba situado en el plano mítico sobrenatural del Más Allá. Su origen pudiera ser la representación del nacimiento de Horus sobre una flor de loto esquematizado como "Árbol de la Vida" formado por 


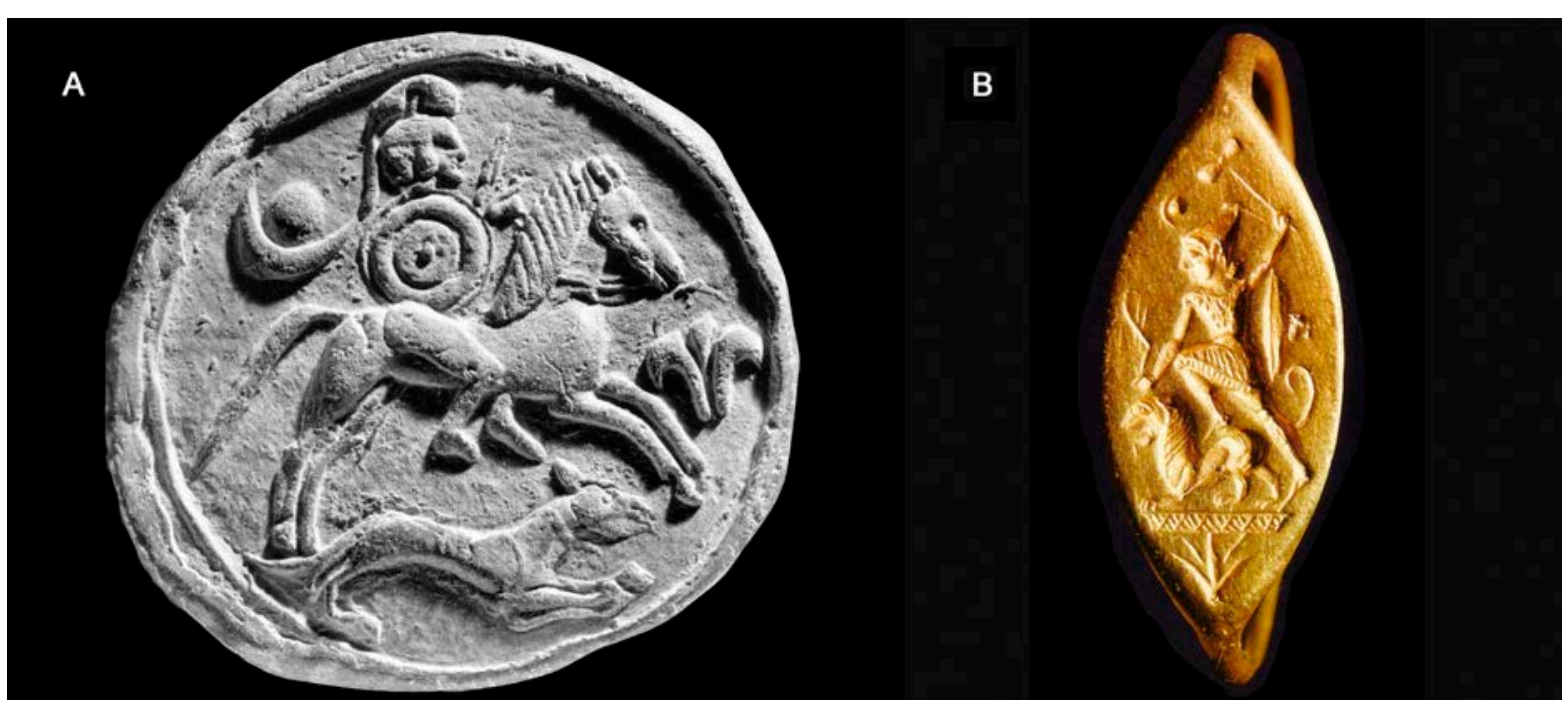

Fig. 23: A, Jinete púnico de Cartago (Fantar 1970: lám. 15). B, Melqart sobre flor de loto en un sello de Cartago (Parrot et al. 1975: fig. 196).

volutas superpuestas en disposición simétrica, como ofrecen algunas placas de marfil orientalizantes de inspiración egipcia (Parrot et al. 1975: fig. 100) y otros ejemplos, como una placa de esteatita de Biblos (id.: fig. 97) o las de marfil de Arslan-Tash (id.: 98 y 100), etc. Estas volutas pueden considerarse el precedente de las que sostienen a estas figuras de jinete ibérico.

La misma iconografía simbólica se asocia a Melqart como rey-héroe divinizado protector de la monarquía de Tiro y de la ciudad. Melqart aparece sobre un zócalo sostenido por una flor de loto (fig. 23, B) en un anillo de oro de Cartago del s. VI a.C. (Parrot et al. 1975: fig. 196), iconografía que perdura en una navaja ritual de afeitar del s. III a.C. (id.: fig. 200). También flores de loto indican el carácter mítico de la escena de una placa ebúrnea de Medellín, Badajoz, del s. VII a.C. que representa a Melqart matando al Toro Celeste (Almagro-Gorbea 2002) y el mismo significado tiene el capitel protoeólico de múltiples volutas de los citados anillos de Aliseda y del capitel de Cádiz, pues su estructura es la misma que ofrecen las figuras citadas de Horus y de Melqart (vid. supra). Todos estos ejemplos indican que el capitel protoeólico se asocia siempre a figuras de carácter sacro y sobrenatural, como lo eran los "Jinetes de tipo La Bastida".

Estas parejas de volutas contrapuestas a modo de capitel eólico también aparecen en otras importantes creaciones del Arte Ibérico. Además del citado bronce jonio-ibérico del "Guerrero sacrificando un carnero" (vid. supra), que se sustenta sobre una doble voluta idéntica a la de los "Jinetes tipo La Bastida", también la Dama de Elche utiliza el simbolismo del doble capitel protoeólico de volutas (García y Bellido 1943: lám. I-III), pues los dos grandes discos que enmarcan su cabeza ofrecen por el interior sendos capiteles protoeólicos para indicar su carácter sobrenatural, al ser la representación heroizada post mortem de una reina, como explicita el simbolismo de los citados capiteles. Esta idea se generalizó en el mundo ibérico como vemos en la diosa entronizada con oferentes de la tumba 114 de la necrópolis del Cabecico del Tesoro, en Verdolay, Murcia, fechado en los ss. IV o III a.C. (García Cano y Page del Pozo 2004: 127 s., no 44), que tiene dos pilares coronados por sendos capiteles protoeólicos que indican el carácter sacro de la escena representada, como ocurre con las dos columnas con capiteles de volutas dispuestas a la entrada de templos o santuarios para indicar su carácter sacro (Almagro-Gorbea y Torres 2010: 258 s.).

Estos paralelos indican que el simbolismo del doble capitel protoeólico usado en el "Guerrero sacrificando un carnero" y en la Dama de Elche es el mismo que ofrecen los "Jinetes de tipo La Bastida", cuya disposición sobre dobles volutas, asociada a su desnudez, confirma su carácter heroico y su ubicación en el plano mítico del Más Allá, fuera del mundo real.

La iconografía de los "Jinetes tipo La Bastida" precisa este significado simbólico. A la misma idea lleva el caballo, un animal considerado desde la Edad del Bronce de carácter sacro, de origen divino y asociado al Sol, pues sustituyó a las aves acuáticas como animal de tiro del carro solar. Al difundirse la equitación por 
Europa y el Mediterráneo a partir del s. VIII a.C., las aristocracias guerreras adoptaron el caballo como símbolo de estatus y de heroización (Almagro-Gorbea 1996: 82 s.; 2005; Almagro-Gorbea y Torres 1999: 87 s.), tras relegar el uso del carro como símbolo regio desde la Edad del Bronce, como evidencia el carácter ecuestre de antepasados míticos protectores de las dinastías gentilicias, como Reso, Diomedes o los Dioscuros (Almagro-Gorbea y Torres 1999: 78 s.).

Este proceso ideológico permite comprender la representación de caballos y jinetes en la iconografía ibérica, en cerámicas y en las esculturas integradas en monumentos sepulcrales de carácter heroico, y también los arneses de caballo depositados en ajuares funerarios como elemento de estatus (Chapa 1980: 852 s.; Almagro-Gorbea 1983: 245;1996: 119; Blánquez 1997; etc.). Es significativo el heroon de Porcuna (Negueruela 1990: 88), que ofrece notables paralelos con estos "Jinetes de tipo La Bastida", tanto estilísticos como en el uso del casco "jonio-ibérico" de gran cimera. El protagonista y vencedor de los combates representados en este heroon monumental es siempre un jinete, un heros equitans o "héroe ecuestre" (Almagro-Gorbea y Torres 1999: 88; Almagro-Gorbea 2005a), que sería el fundador de la estirpe reinante. Aparece representado como caballero, aunque lucha a pie cuerpo a cuerpo para vencer a su enemigo, según la forma de combatir de las elites guerreras del mundo preurbano, que tan bien describe Homero en la Ilíada.

Igualmente, son jinetes heroizados o "divinizados" en el Más Allá las esculturas de la necrópolis de ibérica de Los Villares, en Hoya Gonzalo, Albacete, datados a fines del s. VI e inicios del V a.C. (vid. supra), como otro jinete de Córdoba ya de la segunda mitad del s. V a.C. (Chapa 1985: lám. 20), mientras que el magnífico caballo de Casas de Juan Núñez, Albacete, de mediados del s. V a.C., se asociaría a un héroe ecuestre a pie sosteniendo las riendas (Blech et al. 2001: lám. 218). La misma iconografía repite a inicios del s. I a.C. el heros, probablemente coronado por una Niké o Victoria (Nony 1969: 26; Almagro-Gorbea 1996: 130; Almagro-Gorbea y Moneo 2000: 78 s.), venerado como Héroe Protector en el templo poliádico situado la entrada a la población ibérica de Azaila, Teruel (Beltrán 1995: fig. 92), cuya fecha tardorrepublicana lo relaciona con el jinete representado en numerosas acuñaciones de la numismática hispana (Almagro-Gorbea 1995).
Este heros equitans tenía carácter ctónico y solar (Benoit 1954), como evidencian los signa equitum celtibéricos, siempre decorados con círculos solares (AlmagroGorbea y Torres 1999: 70 y 78 s.). También lo confirma el citado jinete púnico de Douimès de fines del s. VI a.C. (Fantar 1970: 19 s., lám. 15), pues se asocia a una flor con dos volutas (fig. 22, B), como los "Bronces de tipo La Bastida", ya que todas estas piezas representaban la misma creencia de heroización ecuestre extendida por el Mediterráneo entre las elites del final del Arcaísmo, tras la desaparición de las monarquías, cuyos símbolos heredaron para potenciar su poder (Almagro-Gorbea 1996). Este contexto ideológico, sacro y sobrenatural, explica la representación de los "Jinetes tipo La Bastida" sobre un doble capitel eólico como símbolo de divinidad (Almagro-Gorbea y Lorrio 2011: 17 s.).

En resumen, los "Jinetes tipo La Bastida" deben considerarse el remate de cetros que pudieron servir como pequeños estandartes, signa equitum o signa militaria de las elites ibéricas. Al mismo tiempo, eran un símbolo de poder que representaba al Héroe Fundador o antepasado mítico de la estirpe como Heros equitans, como los Penates de Lavinium. Esta figura mítica divina y ecuestre, tenía gran importancia social e ideológica, pues era el Patrono y Protector de quien ostentaba tal insignia, que se consideraría su descendiente, y, por extensión, también protegía a sus familiares, clientes y a todo su pueblo, por lo que era la clave del poder político y constituía un elemento aglutinante de toda la sociedad de acuerdo con la ideología de la época (Almagro-Gorbea 1996: 116 s.; 2005a). De ahí su popularidad, que evidencian los casi veinte ejemplares conocidos y la generalización del "jinete ibérico" en monumentos funerarios ibéricos y en las monedas hispanas (Almagro-Gorbea 1995), hasta el punto de que en esta figura mítica acabó asimilada al Culto Imperial (Almagro-Gorbea y Lorrio 2007a) y ha perdurado en el imaginario popular en la figura ecuestre de Santiago Matamoros o de San Jaime, siempre vencedor en la batalla.

\section{LA DISPERSIÓN DE LOS "JINETES DE TIPO LA BASTIDA”Y SU INTERPRETACIÓN HISTÓRICA}

Los "Jinetes de tipo La Bastida" aparecen por la mitad meridional de la península Ibérica (fig. 24), desde las tierras meridionales del levante, por la Meseta Sur y Andalucía y llegan hasta Extremadura, aunque se desconoce el lugar de hallazgo de casi la mitad de las piezas. 
El Jinete de La Bastida procede de este oppidum ibérico, situado en Mogente, que controlaba el importante corredor de Montesa como paso desde la llanura valenciana a la Meseta. Algo más al $\mathrm{N}$ se supone hallado el Jinete de La Carencia, aparecido en excavaciones clandestinas en este importante oppidum ibérico o en sus contornos (Albiach, coord. 2013: 40). También del territorio meridional de Valencia pudiera proceder el Jinete Bagot por su afinidad tipológica a las piezas anteriores, aunque no existe noticia alguna sobre su lugar y circunstancias del hallazgo, lo mismo que ocurre con el Jinete Chastel. Ya algo más al interior se halló el Jinete del Museo de Cuenca, también recuperado de excavaciones ilícitas. Se supone procedente de una necrópolis de La Manchuela conquense, quizás situada en el término de Castillejo de Iniesta, en el interfluvio que forman el río Júcar y su afluente el Cabriel, territorio controlado por la ciudad ibérica de Ikalesken-Iniesta, una de las más importantes cecas ibéricas (Ripollès 1999).

El lugar de hallazgo de los restantes ejemplares se conoce aún peor. El Jinete Saint-Germain se ha considerado procedente de un "santuario de la provincia de Jaén" (AA.VV. 1998: 329, n 296), pero esta procedencia no es segura, pues a los santuarios jienenses de Sierra Morena se tiende a atribuir muchos hallazgos (Nicolini 1969: 31). Lo mismo cabe decir del Jinete del IVDJ, que se considera procedente del santuario de Despeñaperros sin documentación fehaciente (Moreno 2006: 504, n 231). También plantean dudas los jinetes al parecer hallados en el área granadina. El Jinete Ortiz se publicó como supuestamente procedente del área de Sierra Nevada, lo que debe tomarse con reservas (Ortiz 1996: no 203), y también resulta insegura la procedencia del Jinete de Pinos Puente (Gorny \& Mosch 2008: n 324), en cuyo término se sitúa el importante yacimiento del Cerro de los Infantes-Ilurco (Mendoza et al. 1981; Molina et al. 1983), pero no se ha podido confirmar dicho origen. Más segura parece la procedencia de los jinetes de Espejo-1, Espejo-2 y Montilla, a pesar de desconocerse su contexto arqueológico preciso por ser todos hallazgos casuales. El Jinete de Montilla parece proceder del Cerro Cocorrón, en el que existe un importante asentamiento rural romano de mediados del s. I d.C., sin duda posterior a esta pieza (Alors et al. 2002). Los jinetes de Espejo fueron hallados en ese territorio, según noticias fidedignas, aunque los datos sobre la procedencia concreta resultan inseguros, cuando no claramente contradictorios. Finalmente, el Jinete de Hornachuelos parece haberse hallado en una tumba muy arrasada del s. II a.C. de la necrópolis de "El Peñascón" (Rodríguez Díaz 2003; vid supra), perteneciente al oppidum de Hornachuelos-Fornacis, en Aldea del Fresno, Badajoz.
Fig. 24: Dispersión de los “Jinetes tipo La Bastida". Los asteriscos indican los topónimos en Ili- al S del Júcar.

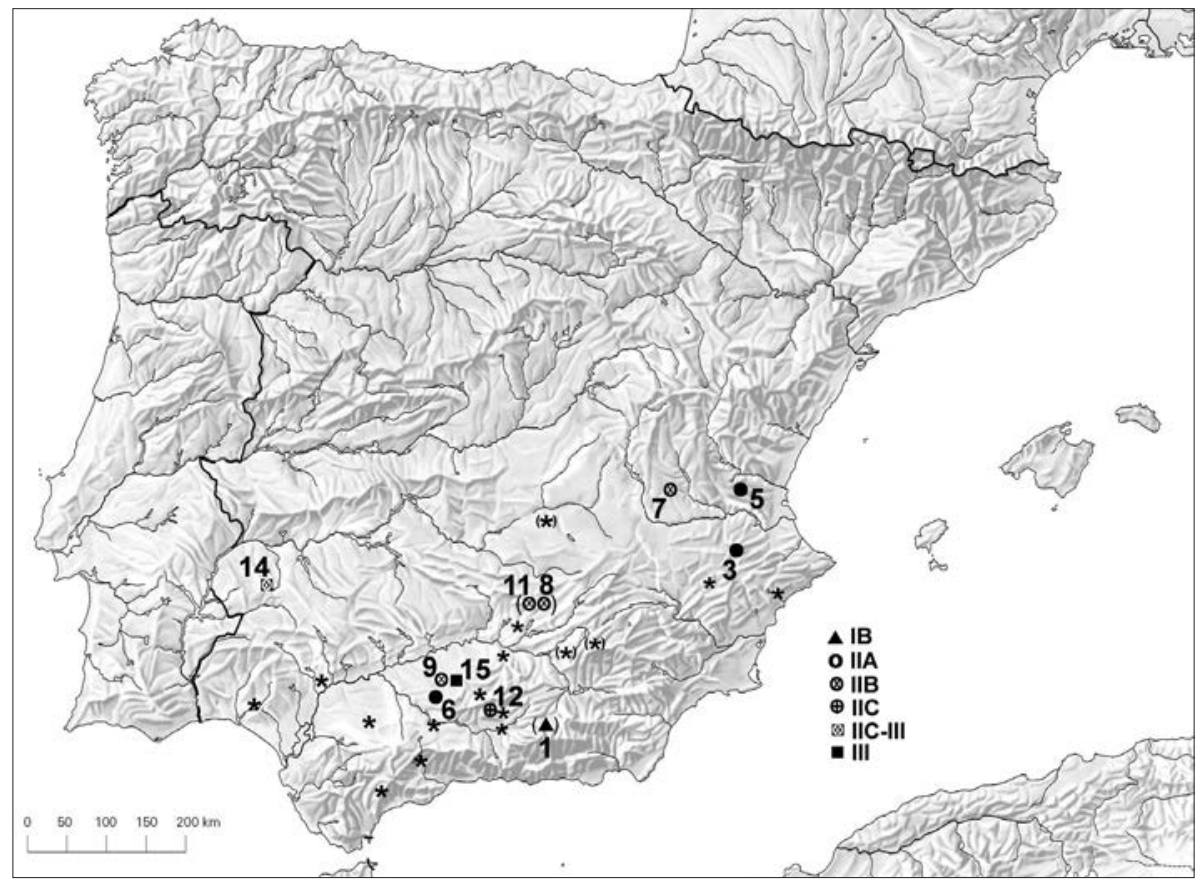


Las restantes piezas, algunas muy importantes, carecen de procedencia, como el Jinete Wace, el Jinete Bagot, el Jinete Segarra, el Jinete del Archivo Cabré, el Jinete Heiss y el Jinete Hermann, del que prácticamente sólo conocemos su existencia. A ello se añaden las dudas señaladas para atribuir el Jinete de la Colección Ortiz a la zona de Sierra Nevada y son igualmente dudosos el lugar de hallazgo del Jinete de Pinos Puente y la procedencia de Despeñaperros de los ejemplares del Museo de SaintGermain-en-Laye y del Instituto del Conde de Valencia de Don Juan.

A pesar de estas incertidumbres, pues sólo proceden de excavaciones arqueológicas dos de los 18 "Jinetes de tipo La Bastida" conocidos, un $11 \%$ del conjunto, es evidente que estos bronces se extienden desde el área ibérica levantina hasta Extremadura. Además, a pesar de que se desconoce el contexto arqueológico de la mayoría de las piezas, el estilo jonio-ibérico de los ejemplares más antiguos indica que son originarios del mundo ibérico del Levante y del SE de Hispania, desde el S de Valencia a Andalucía Oriental, donde el influjo jonio-focense es más patente en la escultura (Chapa 1985) y también en la epigrafía (de Hoz 2011: 390 s.).

Como estos "Jinetes de tipo La Bastida" eran símbolos de poder de la cultura ibérica, su expansión indica también la de influjos ideológicos, quizás asociados a movimientos étnicos, aspectos hasta ahora prácticamente desconocidos, pues de ellos no informan las fuentes escritas a pesar de su evidente interés. Los "Jinetes de tipo La Bastida" aparecen sobre capiteles "protoeólicos" que pudiera proceder del mundo fenicio, pero estos jinetes y otras esculturas ibéricas relacionadas (Almagro-Gorbea 1983: 284 s.; 1996: 92;2005a: 159) ofrecen un característico estilo jonio-ibérico introducido por los focenses desde Emporion que revela el filohelenismo de las elites ibéricas de fines del s. VI y la primera mitad del s. V a.C. Este estilo debió propagarse junto a influjos sociopolíticos e ideológicos focenses, que también se reflejan en el armamento ibérico contemporáneo (Farnié y Quesada 2005). A estos influjos se asociaría la difusión del simbolismo del caballo como elemento de aristocracia y riqueza en el mundo griego arcaico, que debió influir poderosamente en la formación de la aristocracia ecuestre ibérica.

En efecto, el jinete es un tema habitual del arte griego arcaico desde el s. VI a.C., tras las reformas políticas y del ejército, cuando la caballería pasó a ser sinónimo de aristocracia y riqueza (vid. supra), lo que permite suponer que en Emporion el poder lo ostentaran oligarquías ecuestres, como ocurría en Massalia (Arist. Pol., 8,5; Str. 6,3,4), y, aunque se conoce muy mal la organización política focense (Domínguez Monedero 1986; AlmagroGorbea 1996: 245, n. 15), tanto las elites focenses ampuritanas como las ibéricas serían de tipo ecuestre, lo que facilitaría su entendimiento.

La dispersión de "Jinetes de tipo La Bastida" desde el área ibérica del Levante y el Sureste de la Meseta hasta el centro de Andalucía es similar a la que ofrecen los monumentos jonio-ibéricos (Chapa 1985). Con el estilo jonio-ibérico también penetraron formas cerámicas y cráteras griegas usadas e imitadas como urnas cinerarias (Page del Pozo 1984; Pereira y Sánchez 1985: fig. 1-4) y con estos elementos arqueológicos podrían relacionarse la presencia en Andalucía de topónimos en Ili-, indicativos de "ciudad" en ibérico (fig. 24) (de Hoz 2010: 466 s.; Silgo 2013: 155 s.). Estos topónimos denotan influjos en la lengua y parecen revelar movimientos étnicos, quizás incluso debidos a procesos de tipo colonial, como pudieran confirmar los "Jinetes de tipo La Bastida".

En efecto, la penetración de los citados elementos hasta Andalucía Oriental y Central refleja un proceso de "iberización" cultural y quizás también étnica, sobrevenido sobre el substrato orientalizante del mundo tartesio (Torres 2002). Estos cambios debieron tener gran importancia en el contexto histórico de la época. Tartessos desaparece a mediados del s. VI a.C. (Almagro-Gorbea 1996: 79 s.; Torres 2002: 383 s.), tras la conquista de Focea por Harpago, el general de Ciro, el 546 a.C. (Herod. I,163; cf. Almagro-Gorbea et al. 2018). Los focenses, al perder Tartessos, organizaron una red de factorías y aliados para alcanzar las ricas tierras del SE y las explotaciones mineras de Sierra Morena (AlmagroGorbea 1982). En consecuencia, desde fines del s. VI a.C. se constata la penetración de un ambiente filoheleno hacia el interior de la Meseta (Blánquez 1995; 1997) y Andalucía Oriental (Almagro-Gorbea et al. 2004: 228 s.), helenización que llegó al centro de Andalucía, como evidencia el heroon de Obulco datado hacia el 480 a.C. (Negueruela 1990: 302-303; Almagro-Gorbea 1999a: 93), proceso de expansión que confirma la dispersión de los "Jinetes de tipo La Bastida" (fig. 24).

Estos contactos filohelenos en el SE y Andalucía Oriental propician desde fines del s. VI a.C. el desarrollo del estilo greco-ibérico que caracteriza las mejores esculturas ibéricas, como los heroa de Ilici (AlmagroGorbea 1999a), las esculturas ecuestres de Los Villares 
(Blánquez 1997; Blánquez y Sanz Gamo 2010) y el heroon de Obulco (Negueruela 1990). Este filohelenismo también se aprecia en Pozo Moro, pues el monumento turriforme, fechado hacia el 500 a.C., es sin duda obra de artesanos de origen fenicio a juzgar por su estilo y sus narraciones míticas (Almagro-Gorbea 1983), pero su rico ajuar lo forman un oinochoe de bronce, un kylix y un lekythos áticos (id.: lám. 14 y 15). La procedencia griega de este ajuar indica el significativo cambio ocurrido en las corrientes comerciales, en los gustos y en la ideología de la clase dirigente ibérica a fines del s. VI a.C., como confirman las esculturas citadas de Los Villares y del heroon de Obulco y los bronces del "taller de los rizos largos" a inicios del s. V a.C.

Los "Jinetes de tipo La Bastida" ofrecen otro aspecto de indudable interés para comprender las características de esta expansión ibérica filohelena. Estos signa equitum pertenecían a elites ecuestres de tipo regio (vid. supra), como se deduce de su simbolismo ideológico, como indica el contexto arqueológico del "Jinete de La Bastida" y como confirman algunos textos históricos (Caro Baroja 1971). Serían el símbolo de mando de reges de dinastías gentilicias, pero también quizás de hegemones, duces, caudillos o "condotieri" de carácter carismático. Estos personajes dirigirían ejércitos formados por turmae de jinetes integradas en bandas guerreras, con sodalitates o asociaciones de guerreros vinculadas a dichos caudillos por la devotio (Ramos Loscertales 1924; Rodríguez Adrados 1946), ejércitos que se completarían con clientes y siervos.

Estos hegemones o caudillos al frente de sus ejércitos podían llegar a apoderarse de una ciudad-estado y cambiar su dinastía al imponer un nuevo soberano, como repetidamente ocurrió en Italia en el s. VI a.C. hasta el inicio de la República (Torelli 2011). Estos ejércitos itálicos del final del arcaísmo ofrecen distintas formas de organización y de sistema de mando cuando realizaban expediciones militares asociadas a procesos de conquista y colonización, favorecidas por el desarrollo demográfico de las ciudades-estado a fines del s. VI a.C. Podían estar dirigidas por el rex de una ciudad y ofrecer una organización urbana, como la expedición dirigida el 508 a.C. contra Roma por el rey de Clusium, Lars Porsenna, quien, según algunas fuentes, llegó a conquistar la ciudad (Ehlers 1953; Ridley 2015; 2017). Otros ejércitos podían ser de tipo gentilicio y clientelar, como los de los Claudios (Serv. ad Verg. 7,706) y los Fabios (id. 6,845), en cuya conocida guerra privada contra Veies fueron prácticamente aniquilados el
477 a.C. en la batalla de Cremera (Liv. 2,197-198; Serv. ad Verg. 6,845: ...trecenti et sex fuerunt de una familia Fabiorum, qui cum coniurati cum servis et clientibus suis contra Veientes dimicarent). También había ejércitos dirigidos por un hegemón, caudillo o "condottiero" de fortuna, al que quedaban vinculados por medio de la devotio. Bien conocido es el caso de Macstrna-Servio Tulio (c. 578534 a.C.), quien, al servicio de Aulo y Celio Vibenna, dos jefes etruscos originarios de Vulci, llegó a apoderarse de Roma y fue nombrado rey (Vernole 2002: 165 s.; Laurendi 2011). Otro ejemplo es la expedición contra Satricum de Publio Valerio Poplicola hacia el 500 a.C., cuyos sodales o compañeros le dedicaron una inscripción (Stibbe et al. 1980; Bloch 1982; Arcella 1992; Hermon 1999). Otro caso es la conquista de Cumas por un complejo ejército etrusco el 524 a.C. (Torelli 1981: 196) o la contemporánea conquista de ciudades laciales por los Volscos. En ocasiones estas expediciones de conquista y colonización podían adoptar el rito ancestral del ver sacrum, como la fundación de Capena por iuvenes de Veio (Serv. ad Verg. 7,797 = Cato, Origines, 2,17J; cf. Hermon 1999: 864 s.) o la conquista de Mesina el 288 a.C. por una expedición de Mamertinos (Festo, 150L).

En Hispania, como en Italia, también debieron ser habituales las expediciones militares dirigidas por reges, hegemones o caudillos al frente de ejércitos gentilicios formados por familiares y clientes, aunque el menor tamaño y demografía de los oppida ibéricos (AlmagroGorbea 1988; Moret 1996) supone que esos ejércitos serían también menores. Si el resultado de una expedición era propicio, podían apoderarse de una ciudadestado con su territorio y dar lugar a una "colonización" o asentamiento de nuevas gentes con una nueva dinastía, como testimoniaría el heroon de Porcuna (Negueruela 1990), monumento que parece haberse construido para enaltecer al conquistador de Obulco y fundador de una nueva dinastía.

Este contexto histórico ayuda a comprender el significado de estos "Jinetes de tipo La Bastida" como insignias de los reges y hegemones ibéricos, quienes, favorecidos por la tradición de la devotio ibérica, podrían hacer la guerra por su cuenta o actuar como mercenarios (Graells 2014). La organización de turmae de jinetes dirigidas por el rex o por un magister equitum está atestiguada repetidamente en Iberia desde el arcaísmo final como evidencia el estilo jonio-ibérico de los más antiguos "Jinetes de tipo La Bastida", pero esta tradición perduró hasta el Imperio. Un caso famoso es el 
de Moerico en Sicilia, que recibió el 211 a.C. de Roma 500 yugadas en Morgantina (Liv. 26,21,9 s.), cifra que permite calcular que tenía a sus órdenes 100 jinetes (Almagro-Gorbea 2012). Otro ejemplo es el de Alucio, príncipe ibero que se presentó a Escipión el 209 a.C. con 1400 jinetes de sus clientes (Liv. 26,50 s.: dilectu clientium habito cum delectis mille et quadringentis equitibus... ad Scipionem reuertit) o Indíbil, regulus ilergete que pereció luchando cum equitibus el 205 a.C. (Liv. 29,2,13). Mejor documentada está la Turma Saluitana, formada 30 vascones e iberos, que fue premiada por Cn. Pompeyo el 89 a.C. (CIL I, 709; Criniti 1970: 182 s.) o el interesante episodio ocurrido el 45 a.C., en la Guerra Civil entre César y los seguidores de Pompeyo, cuando perece en combate un "rey llamado Indo mientras conducía sus tropas al frente de la caballería" (b.H.10: rex nomine Indo qui cum equitatu suas copias adduxerat...). También se documentan ejemplos similares entre los celtíberos, como los quadraginta nobiles equites que T. Sempronio Gracco incorporó a su ejército en la ciudad celtibérica de Certima (Liv. 40,47), y el mismo carácter debió tener Caro, elegido jefe de los segedenses y arévacos el 153 a.C. (Ap. Ib. 45), Retogenes en Numancia (id.93), etc.

Estos bronces eran símbolo de elites ecuestres ibéricas de tipo heroico y su aparición por Andalucía, en zonas pertenecientes al mundo tartésico, revela cambios ideológicos, políticos y étnicos. Estos cambios penetrarían junto al estilo greco-ibérico, que atestiguan dinastías ibéricas de tendencia filohelena, a los que se asociarían cambios sociales e ideológicos, ya que dichas elites ibéricas compartirían con las focenses conceptos heroicos parecidos, originarios del mundo indoeuropeo. La concepción ideológica de estas nuevas monarquías ibéricas sería opuesta a la de las monarquías sacras tartesias de tipo oriental al quedar más próxima a la cultura griega y a su ideología, en la que se inspiraban. Esta proximidad ideológica facilitaría las alianzas filohelenas, por lo que la oposición entre los tartesios apoyados por el mundo fenicio colonial y estas elites ibéricas apoyadas por los focenses sería tanto económica como ideológica (Almagro-Gorbea 1996). Los griegos favorecerían a estas monarquías de tipo heroico frente a las monarquías sacras de tradición orientalizante y de tendencia filopúnica en las luchas surgidas entre el área de tradición orientalizante y de influencia feno-púnica de Andalucía y el área grecofocense del Levante y del SE, cuya expansión sobre la anterior se documentan a partir de inicios del s. V a.C.
Las expediciones militares favorecerían las rivalidades y luchas entre las monarquías ibéricas y explican mejor las frecuentes destrucciones de monumentos por su significado socio-político (Almagro-Gorbea y Torres 2010: 369). El apogeo del filohelenismo ibérico coincide con una creciente presión griega en el Mediterráneo tras las Guerras Médicas y la batalla de Himera en Sicilia, ocurrida el 480 a.C., contexto histórico que debió favorecer la penetración de ideas y de gentes filohelenas hacia el valle del Guadalquivir siguiendo la vía Heraclea en sentido contrario a como se habían difundido anteriormente los influjos económicos, culturales, políticos e ideológicos orientalizantes desde Tartessos hacia el área ibérica (Torres 2002). En consecuencia, la expansión de estas elites filohelenas debió suponer una iberización helenizante de áreas tartesias del centro de Andalucía.

Con estos influjos ibéricos se pudieron introducir cambios lingüísticos, como los topónimos en Ili- característicos de toda el área ibérica que se documentan en Andalucía (de Hoz 2010: 466 s.; Silgo 2013: 155 s.). La posible introducción de estos topónimos pudiera relacionarse con las esculturas de estilo jonio-ibérico y con los "Jinetes tipo La Bastida", pues se superponen a topónimos en -ippo- y en - uba del substrato tartesio anterior (Untermann 1985: 15, mapas 1, 2 y 5), por lo que indican la presencia de gentes de habla ibérica por toda Andalucía. Topónimos en Ili- (fig. 24) aparecen en Ilici, La Alcudia de Elche, Alicante (TIR 2001: 200), Ilunum, en El Tolmo de Minateda, Hellín, Albacete (Abad 1996: 97; TIR 2001: 204), Iliberi, en el Albaicín de Granada (Tovar 1974: 127 s.; TIR 2001: 199) e Ilurco (Tovar 1974: 136; TIR 2001: 205), situada en el Cerro de los Infantes de Pinos Puente, Granada, de donde procedería uno de estos jinetes. Entre los Oretanos estaba Ilugo, en Santiesteban del Puerto (TIR 2001: 205 s.), Iliturgi, en el Cortijo de Maquíz, Mengíbar, ambas en Jaén (Tovar 1974: 109 s.; TIR 2001: 202 s.) e Iltiraka, ceca de ubicación desconocida en el Alto Guadalquivir (TIR 2001: 204), y en la Turdetania, Iliturgicola (Tovar 1974: 123; TIR 2001: 179), en el Cerro de las Cabezas?, FuenteTójar, entre Priego y Carcabuey, Córdoba, no lejos de Espejo y Montilla, Ilipula Minor, en Montemolín, Marchena o en el Cortijo de Repla, Los Corrales, Lucena (Tovar 1974: 129; TIR 2001: 202), Illipula Magna, al S del Guadalquivir, quizás en Loja (Tovar 1974: 139; TIR 2001: 203), que se suele identificar con Ilipula Halos o Ilipula Laus, de localización incierta (TIR 2001: 201-202), 
Illipula mons, en la Sierra de Ronda (TIR 2001: 203) e Iluro (Tovar 1974: 132 s.; TIR 2001: 205 s.), en Álora, en el valle malacitano del Guadalhorce. Estos topónimos prosiguen hasta Ilipa Magna, en Alcalá del Río, Sevilla (Tovar 1974: 162; TIR 2001: 201) e Ilipla (Tovar 1974: 168; TIR 1995: 91), Niebla, en la provincia de Huelva.

Esta penetración de turmae ibéricas filohelenas desde el SE hacia Andalucía a inicios del s. V a.C. también se podría relacionar con el oscuro episodio de un ataque a Cádiz por el rey ibérico Terón, que refiere Macrobio en sus Saturnalia $(\mathrm{I}, 20,12)$, y otra alusión aún más incierta ofrece Justino $(44,5,1)$ sobre una victoria de los gaditanos sobre sus vecinos con ayuda de Cartago. Estos enfrentamientos mítico-históricos parecen reflejar la rivalidad señalada entre griegos y púnicos a lo largo del s. V a.C. y la presión de ejércitos ibéricos filohelenos dirigidos por sus elites ecuestres. Según Macrobio, Terón era un rey de la Hispania Citerior, por lo que procedía del levante, del SE o de Andalucía oriental (Almagro-Gorbea 2013: 223 s.), lo que excluye a Tartessos, como indicaron Maluquer (1970: 48-49) y Alvar (1986), quien supuso que sería un régulo de la Contestania de mediados del s. IV a.C., que, con ayuda de los griegos del levante, pretendió conquistar Cádiz, fracasando en el intento. Esta noticia puede situarse en el contexto histórico de la expansión ibérica a partir del s. V a.C. que documentan los topónimos en Iliy los "Jinetes de tipo La Bastida" y los restantes elementos culturales citados. Como se constata en Italia a partir de fines del s. VI a.C., también en Hispania parece apreciarse una "colonización" ibérica surgida a partir de expediciones guerreras, dirigidas por elites aristocráticas ecuestres, probablemente de tipo regio, que constituían un elemento esencial de su sociedad y de su cultura, como ocurría en otras culturas del Mediterráneo. Este es el interés histórico que ofrecen los "Jinetes de tipo La Bastida" al documentar la expansiónde dichas elites hacia las zonas centrales de Andalucía.

\section{RECAPITULACIÓN}

Los "Jinetes de tipo La Bastida" son un grupo de piezas de gran calidad que se deben incluir entre los más destacados bronces ibéricos. Ofrecen homogeneidad estilística y tipológica, pues responden a un mismo modelo iconográfico: un jinete con un casco de tipo jonio-ibérico con alta cimera que cae por detrás. La figura, en actitud de parada, representa la epipháneia o aparición sobrenatural del heros equitans sustentado sobre dos pares de volutas que esquematizan capiteles protoeólicos como símbolo del "Árbol de la Vida" para indicar el carácter sacro y sobrenatural de la figura y su ubicación en el plano mítico del Más Allá. Además, ese soporte servía para enmangar la figura del jinete sobre un astil de madera para llevarla como cetro, insignia o signa equitum.

Estos bronces, desde un punto de vista ideológico, deben ser considerados la imagen sagrada del heros equitans como antepasado mítico de las elites ecuestres, por lo que eran la representación de los Penates del Héroe fundador, figura mítica que era el Patrono y Protector. Este simbolismo explica la aceptación y popularidad de este tipo iconográfico hasta fechas muy avanzadas, pues dio origen al conocido "jinete ibérico" de la moneda hispánica, en las que debe verse al héroe fundador y protector de las poblaciones que las acuñaban.

Las características estilísticas de estos bronces indican que proceden de un modelo jonio-ibérico de gran calidad plástica, pero con elementos del mundo fenicio, como las dobles volutas que lo sustentan. Aunque se desconoce el contexto arqueológico de casi todas las piezas, su seriación permite diferenciar tres grupos, que se fechan desde finales del s. VI a.C. los modelos más próximos al prototipo jonio, hasta el s. II a.C. las piezas de peor arte y estilo, ya contemporáneas de los signa equitum celtibéricos

Estos signa equitum o estandartes deben considerarse un elemento característico del mundo ibérico, pues eran un símbolo de poder de las elites aristocráticas ecuestres que gobernaban la sociedad y cuyo carácter regio parece confirmar el contexto del "Jinete de La Bastida", una de las piezas de mayor calidad y más segura procedencia. $\mathrm{Su}$ carácter aristocrático se relaciona con las esculturas ibéricas de jinetes que coronarían monumentos funerarios, como las de Los Villares y Casas de Juan Núñez en Albacete, y los jinetes del heroon de Porcuna, en Jaén. La expansión por Andalucía de esos monumentos, paralela a la de los "Jinetes de tipo La Bastida" y a la de topónimos en $I l i-$, tiene el interés histórico de indicar una posible expansión ibérica hasta el corazón de Andalucía dirigida por elites filohelenas.

Los "Jinetes de tipo La Bastida", por todo lo dicho, constituyen uno de los más significativos objetos de la Arqueología Ibérica y deben incluirse entre los más interesantes bronces ibéricos. 


\section{ADDENDUM}

Cuando este artículo ya estaba compuesto, ha aparecido un nuevo signum equitum, que por su interés incorporamos en este addendum.

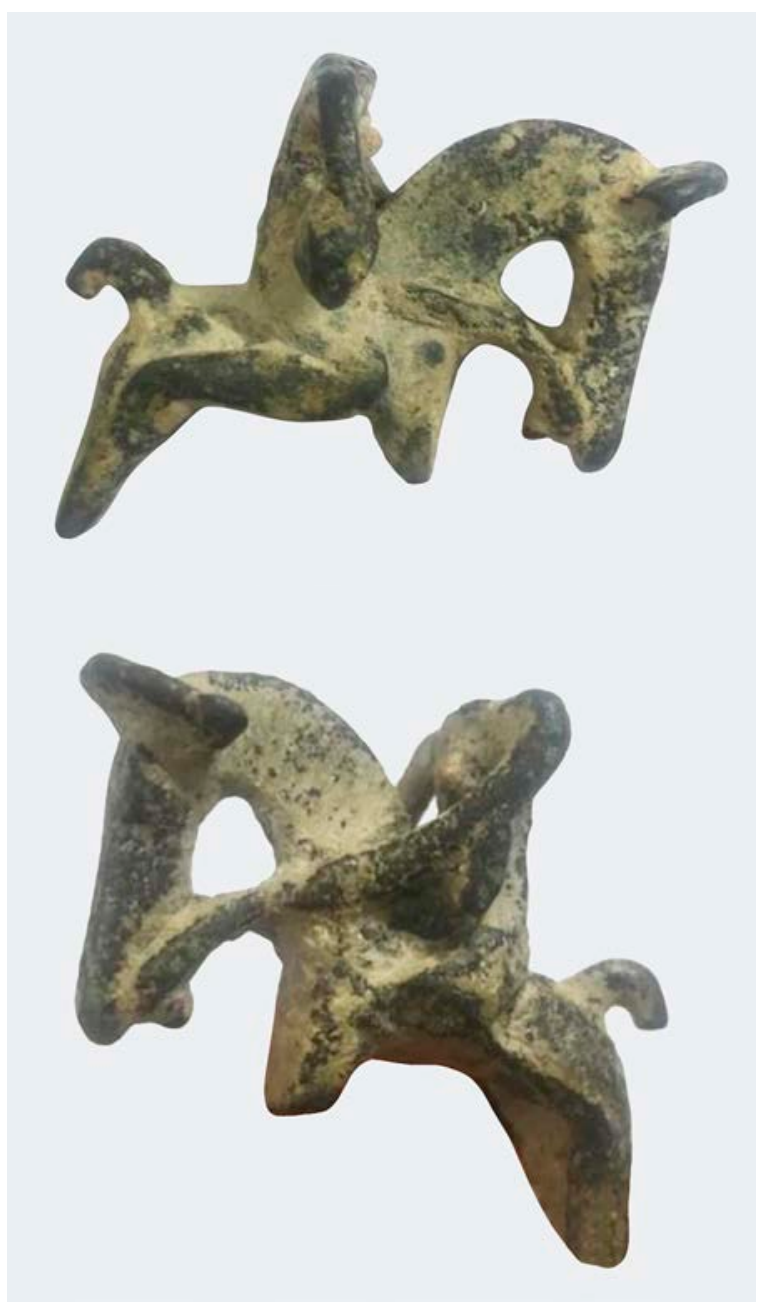

\section{“JINETE DE LA COLECCIÓN CHASTEL”}

Figura de bronce de un jinete, hecha a la cera perdida. Está fracturada y ha perdido la cabeza del jinete, el final de la cola del caballo y la parte inferior de las patas con los elementos de sustentación.

El cuerpo del jinete, muy estilizado, ofrece brazos de sección circular que se prolongan en las bridas del caballo y ofrece las piernas dobladas hacia atrás en ángulo recto y pegadas al cuerpo del caballo hasta alcanzar los cuartos traseros del equino, como los jinetes $n^{\circ} 4$ y 5 y conserva rota restos de la falcata que llevaba cruzada en la cintura, como los jinetes $\mathrm{n}^{\circ} 4$ y 6 . El caballo también es muy estilizado, con formas curvas suaves, con el arranque de la cola hacia arriba como el jinete $\mathrm{n}^{\circ} 5$, la cabeza con las bridas y un penacho semicircular en forma de abanico en su parte superior.

Los detalles citados y su estilo lo aproximan al "Jinete de La Carencia”, hasta el punto de que pudieran proceder ambas piezas del mismo taller.

Dimensiones: Desconocidas.

Procedencia y paradero actual: Desconocidos.

Bibliografía: Inédito.

\section{NOTAS}

1. La composición química de los jinetes Espejo-1 y Espejo-2 ha sido determinada mediante análisis por espectometría de fluorescencia de rayos $\mathrm{X}$ en dispersión de energías.

2. Estas interesantes sugerencias las agradecemos al Dr. Raimon Graells, que ha enriquecido con sus críticas y observaciones el texto originario.

\section{BIBLIOGRAFÍA}

AA.VV. (1998): Los Iberos. Príncipes de Occidente, Barcelona.

AA.VV. (2010): Catàleg del Museu Frederic Marés 5. Catàleg d'escultura i col-lecions del món antic, Barcelona.

ABAD, L. (1996): La epigrafía del Tolmo de Minateda (Hellín, Albacete) y un nuevo municipio romano del Conuentus Carthaginensis, AEA 69, 77-108. DOI: https://doi.org/10.3989/aespa.1996.v69.235

AKURGAL, E. (1969): Orient et occident. La naissance de l'art grec, Paris.

AKURGAL, E. (2000): The Aegean Birth place of Western Civilization, Izmir.

ALBIACH, R. (coord.) (2013): L'oppidum de la Carència de Torís i el seu territori, Serie Trabajos Varios. S.I.P. 116, València.

ALFÖLDI, A. (1965): Die Herrschaft der Reiterei in Griechenland und Rom nach dem Sturz der Könige, Festchrift K. Scheford, Bern, 13-47.

ALFÖLDI, A. (1974): Die Struktur des voretruskischen Römerstaat, Heidelberg.

ALLEN, D. (1980): The Coins of Ancient Celts, (D. Nash, ed.), Edinburgh.

ALMAGRO-GORBEA, M. (1977): El Bronce Final y el Período Orientalizante en Extremadura, Bibliotheca Praehistorica Hispana 14, Madrid. 
ALMAGRO-GORBEA, M. (1982): La ‘colonización' focense en la Península Ibérica. Estado de la cuestión, La Parola del Passato 104-107, 432-444.

ALMAGRO-GORBEA, M. (1983): Pozo Moro. El monumento orientalizante, su contexto socio-cultural y sus paralelos en la arquitectura funeraria ibérica, Madrider Mitteilungen 24, 177-392.

ALMAGRO-GORBEA, M. (1988): El área superficial de las poblaciones ibéricas, Los asentamientos ibéricos ante la romanización (Madrid, 1986), Madrid, 21-34.

ALMAGRO-GORBEA, M. (1995): La moneda hispánica con jinete y cabeza varonil ¿Tradición indígena o creación romana?, Zephyrus 48, 235-266.

ALMAGRO-GORBEA, M. (1996): Ideología y Poder en Tartessos y el mundo ibérico, Discurso de ingreso en la Real Academia de la Historia, Madrid.

ALMAGRO-GORBEA, M. (1998): Signa equitum de la Hispania céltica, Complutum 9, 101-115.

ALMAGRO-GORBEA, M. (1999): Estructura socio-ideológica de los oppida celtibéricos, VII Coloquio Internacional sobre Lenguas y Culturas Paleohispánicas (Zaragoza (1997), Salamanca, 35-55.

ALMAGRO-GORBEA, M. (1999a): El rey-lobo de La Alcudia de Ilici, Alicante.

ALMAGRO-GORBEA, M. (2002): Melqart-Heracles matando al Toro Celeste en una placa ebúrnea de Medellín, AEA 75, 59-73.

DOI: https://doi.org/10.3989/aespa.2002.v75.128

ALMAGRO-GORBEA, M. (2005): El conjunto de varas castellanas, Catálogo de la Real Academia de la Historia. Siglos XVI a XX (J. Maier, ed.), Madrid, 49-55.

ALMAGRO-GORBEA, M. (2005a): Ideología ecuestre en la Hispania prerromana, Gladius 25, 151-185. DOI: https://doi.org/10.3989/gladius.2005.27

ALMAGRO-GORBEA, M. (2009): El kýlix de figuras rojas arcaicas de Pozo Moro (Albacete), CPAC 27, 63-81.

ALMAGRO-GORBEA, M. (2012): Moerico, Diccionario Biográfico Español XXXV, Madrid, 357-359.

ALMAGRO-GORBEA, M. (2013): Literatura Hispana Prerromana. Las creaciones fenicias, tartesias, iberas, celtas y vascas, Clave Historia 39, Madrid.

ALMAGRO-GORBEA, M. (2016): 'Lancea', palabra lusitana, y la etnogénesis de los 'Lancienses', Complutum 27, 1, 131-168.

DOI: https://doi.org/10.5209/CMPL.53220

ALMAGRO-GORBEA, M.; CASADO, D.; FONTES, F.; MEDEROS, A.; TORRES, M. (2004): Prehistoria. Antigüedades Españolas I, Catálogo del Gabinete de Antigüedades de la Real Academia de la Historia, I.2.1, Madrid.

ALMAGRO-GORBEA, M.; GONZÁLEZ DE CANALES, F.; LLOMPART, J. (2018): Un ánfora ática de la 'Botkin Class' en Huelva y la fecha final del emporion focense, Madrider Mitteilungen 59, 282-297.
ALMAGRO-GORBEA, M.; GUERRERO, V. M. (2009): La guerra en el mar, Prehistoria y Antigüedad, Historia Militar de España, I (M. Almagro-Gorbea, coord.), Madrid, 347-364.

ALMAGRO-GORBEA, M.; LORRIO, A. J. (2007): El signum equitum ibérico del Museo de Cuenca y los bronces tipo 'Jinete de La Bastida', I Jornadas de Arqueología de Castilla-La Mancha (Cuenca 2005), Cuenca, 17-51.

ALMAGRO-GORBEA, M.; LORRIO, A. J. (2007a): De Sego a Augusto, los orígenes celtibéricos de Segobriga, BSAA. Arqueología 72-73, 206-477.

ALMAGRO-GORBEA, M.; LORRIO, A. J. (2010): El Heros Ktístes y los símbolos de poder de la Hispania prerromana, $V I$ Simposio sobre celtiberos: Ritos y Mitos (F. Burillo, ed.), Zaragoza, 157-181.

ALMAGRO-GORBEA, M.; LORRIO, A. J. (2011): Teutates. El Héroe Fundador y el culto heroico al antepasado en Hispania y en la Keltiké, Bibliotheca Archaeologica Hispana 36, Madrid.

ALMAGRO-GORBEA, M.; LORRIO, A. J.; SIMÓN, J. L. (2016): Los pilares-estela de la Necrópolis de Capuchinos (Caudete, Albacete), APAUM 31, 59-84.

ALMAGRO-GORBEA, M.; MONEO, T. (2000): Santuarios urbanos en el mundo ibérico, Bibliotheca Archaeologica Hispana 4, Madrid.

ALMAGRO-GORBEA, M.; TORRES, M. (1999): Las fíbulas de jinete y de caballito. Aproximación a las elites ecuestres y su expansión en la Hispania céltica, Institución "Fernando el Católico", Zaragoza.

ALMAGRO-GORBEA, M.; TORRES, M. (2010): Escultura Fenicia en Hispania, Bibliotheca Archaeologica Hispana 32, Madrid.

ALORS, R.; LARA, J. M.; LACORT, P. J. (2002): El yacimiento romano de Cerro Cocorrón (Montilla, Córdoba), Boletín de la Asociación Provincial de Museos Locales de Córdoba 3, 125-139.

ALVAR, J. (1986): Theron, rex Hispaniae Citeriores (Macr., Sat. I, 20, 12), Gerion 4, 161-175.

ÁLVAREZ-OSSORIO, F. (1941): Catálogo de los exvotos de bronce ibéricos. Museo Arqueológico Nacional, Madrid.

ÁLVAREZ-SANCHÍs, J. (1999): Los Vettones, Bibliotheca Archaeologica Hispana 1, Madrid.

AMANDRY, P. (1953): La colonne des Naxiens et le portique des Athéniens, Fouilles de Delphos II, Paris.

AMY, P. (1962): L'arc d'Orange, XV supplément à Gallia, Paris.

ANDERSON, J. K. (1961): Ancient Greek Horsemanship, Berkeley-Los Angeles.

ARCELLA, L. (1992): L'iscrizione di Satricume il mito di Publio Valerio, Studi e Materiali di Storia delle Religioni, N. S. $16,219-249$.

BALLESTER, I. (1931): Diario de Excavación de La Bastida (Les Alcuses) $n^{\circ} 38$, inédito.

BALLESTER, I. (1932): La labor del Servicio de Investigación Prehistórica y su Museo en el pasado año 1931, Valencia.

BARNETT, R. D. (1961): Assyrian Palace Reliefs, Prague. 
BARON, CH. A. (2013): Timaeus of Tauromenium and Hellenistic Historiography, Cambridge. DOI: https://doi.org/10.1017/CBO9780511733246

BELTRÁN, M. (1995): Azaila. Nuevas aportaciones deducidas de la documentación inédita de Juan Cabré Aguiló, Zaragoza.

BENOIT, F. (1954): L'Héroïsation équestre, Aix-en-Provence.

BETANCOURT, P. P. (1977): The Aeolic Style in Architecture, Princeton, N. J.

BITTEL, K. (1976): Los Hititas, Madrid.

BLANCHET, A. (1905): Traité des monnaies Gauloises, Paris.

BLÁNQUEZ, J. (1995): La necrópolis tumular de Los Villares (Hoya Gonzalo, Albacete), El mundo ibérico: una nueva imagen en los albores del año 2000, Albacete, 238-245.

BLÁNQUEZ, J. (1997): Caballeros y aristócratas del s. V a. C. en el mundo ibérico, Iconografía ibérica-Iconografía itálica: propuestas de interpretación y lectura, Madrid, 211-234.

BLÁNQUEZ, J. J.; SANZ GAMO, R. (2010): Caballeros ibéricos en torno a la vía Hercúlea. Una mirada sobre la escultura ibérica, Arqueología, sociedad, territorio, y paisaje: estudios sobre prehistoria reciente, protohistoria y transición al mundo romano en homenaje a $M^{a}$ Dolores Fernández. Posse, Madrid, 253-278.

BLÁZQUEZ, J. M. (1975): Tartessos y los orígenes de la colonización fenicia en Occidente, 2 ed., Salamanca.

BLECH, M.; KOCH, M.; KUNST, M. (2001): Denkmäler der Frühzeit, Hispania Antiqua, Mainz.

BLOCH, R. (1982): À propos de l'inscription latine archaïque trouvée à Satricum, Latomus 42, 362-371.

BONET, H.; DÍES, E.; ÁLVAREZ, N.; PÉREZ JORDÀ, G. (1997): La Bastida de les Alcusses (Moixent): resultados de los trabajos de excavación y restauración. Años 1990-1995, APL XXII, 215-295.

BONET, H.; VIVES-FERRÁNDIZ, J. (2011): De la fundación al abandono. Trayectoria histórica del poblado y sus ocupantes, La Bastida de les Alcusses. 1928-2010 (H. Bonet, J. vives-Ferrándiz, eds.) València, 238-255.

BRUNAUX, J.-L.; LAMBOT, B. (1987): Guerre et armement chez les Gaulois (450-52 a.C.), Paris.

CARO BAROJA, R. (1971): La 'realeza' y los reyes en la España Antigua, Cuadernos de la Fundación Pastor 17, Madrid, 51159.

CELESTINO, S.; ZULUETA, P. DE (2003): Los bronces de Cancho Roano, Cancho Roano IX. Los materiales arqueológicos (S. Celestino, ed.), Mérida, 9-123.

CHAPA, T. (1980): La escultura zoomorfa ibérica en piedra, Tesis Doctoral de la Universidad Complutense, Madrid.

CHAPA, T. (1985): La escultura ibérica zoomorfa, Madrid.

CHOCHOROWSKI, J. (1993): Ekspansja kimmeryjska na tereny Europy Środkowej, Krakow.

CLARKE, D. L. (1968): Analytical Archaeology, London.

CORDANO, F. (2007): Il bastone sonoro del poeta, Aristonothos 1, 89-92.
CRAWFORD, M. H. (1974): Roman Republican Coinage, Cambridge. CRINITI, N. (1970): L'epigrafia di Ausculum di Gn. Pompeo Strabone, Milano.

CROUWEL, J.-H.; TATTON-BROWN, V. (1988): Ridden horses in Iron Age Cyprus, Report of the Department of Antiquities, Cyprus, 1988, 2, 77-87.

CURTIS, J. E.; TALLIS, N. (eds.) (2005): Forgotten Empire. The world of Ancient Persia, London.

D’ANNA, G. (1982): Il sincretismo dei Penati e dei Dioscuri a Lavinio, Il senso del culto dei Dioscuri in Italia (AA.VV.), Taranto, 133-154.

DANTINE, H. (1938): Le palmier-dattier et les arbres sacrés dans l'iconographie de l'Asie occidentale ancienne, Paris.

DE FRANCISCI, P. (1959): Primordia Civitatis. Roma.

DE SIMONE, C. (2002): Latino magister ('capo'), etrusco mastarna - macsterna: che ordine de resazzione?, Rivista di Filologia e Istruzione Classica 130, 430-456.

DESROCHES-NOBLECOUT, C. (1963): Vie et mort d'un pharaon. Toutankhamon, Paris.

DÍES CUSÍ, E.; ÁLVAREZ GARCÍA, N. (1998): Análisis de un edificio con posible función palacial: la casa 10 de la Bastida de les Alcuses (Moixent), Los Íberos, principes de Occidente (C. Aranegui, ed.), València, 327-341. (https://ojs. uv.es/index.php/saguntumextra/issue/view/199)

DOMÍNGUEZ MONEDERO, A. (1986): La ciudad griega de Emporion y su organización política, AEA 59, 3-12.

DONAGHY, TH. (2014): Horse Breeds and Breeding in the GrecoPersian World. 1st and 2nd Millennium BC, Newcastel.

DONDER, H. (1980): Zaumzeung in Griecheland und Cyprus (Praehistorische Bronzefunde 16,3), München.

DUBOURDIEU, A. (1989): Les origines et le développement $d u$ culte des Pénates à Rome, Rome.

DUCREY, P. (1985): Guerre et guerriers dans la Gréce antique, Paris.

EAVERLY, M. A. (1995): Archaic Greek Equestrian Sculpture, Michigan.

EHLERS, W. (1953): Porsenna, Real-Encyclopädie der klassischen Altertumswissenschaft, 22 (Pauly-Wissowa, eds.), 315-322.

EVANS, D. E. (1967): Gaulish Personal Names, Oxford.

FANTAR, M. (1970): Eschatologie phénicienne et punique, Tunis.

FARISELLI, A. C. (2013): Stato sociale e identità nell'Occidente fenicio e punico, I. Le armi in contesto funerario, Bibliotheca di Byrsa 8, Lugano.

FARNIÉ, C.; QUESADA, F. (2005): Espadas de hierro, grebas de bronce. Símbolos de poder e instrumentos de guerra a comienzos de la Edad del Hierro en la Península Ibérica, Monografías del Museo de Arte Ibérico de El Cigarralero 2, Murcia.

FERNÁNDEZ-MIRANDA, M.; OLMOS, R. (1986): Las ruedas de Toya y el origen del carro en la Península Ibérica, Madrid.

FERNÁNDEZ NIETO, F. J. (2018): Textiles y coberturas para uso animal en el Mediterráneo antiguo, Instituta Hispaniae Celtica, Sevilla, 95-113. 
FORRER, R. (1908): Keltische Numismatik der Rhein- und Donaulande (reed. Graz 1968).

FREY, O. H. (1991): La formazione della cultura di La Tène nel V secolo a.C., I Celti, Milano, 127-146.

GARCÍA CANO, J. M. (1997): Las necrópolis ibéricas de Coimbra del Barranco Ancho (Jumilla. Murcia). I. Las excavaciones y estudio analítico de los materiales, Murcia.

GARCÍA CANO, J. M.; PAGE DEL POZO, V. (2004): Terracotas y vasos plásticos de la necrópolis del Cabecico del Tesoro, Verdolay, Murcia, Monografías del Museo de Arte Ibérico de El Cigarralero 1, Murcia.

GARCÍA Y BELLIDO, A. (1943): La Dama de Elche y el conjunto de piezas arqueológicas reingresadas en España en 1941, Madrid.

GARCÍA GONZÁLEZ, D.; LÓPEZ CHAMIZO, S.; GARCÍA ALFONSO, E. (eds.) (2018): La Tumba del Guerrero. Un enterramiento excepcional en la Málaga fenicia del siglo VI a.C. Sevilla.

GHIRSHMAN, R. (1964): Ancient Iran. From Its Origins to the Time of Alexander the Great, London.

GORNY \& MOSCH (2008): Giessener Münzhandlung, Auktion 174. Kunst der Antike 16 Dezember 2008, München.

GRAELLS, R. (2014): Mistophoroi ex Iberias. Una aproximación al mercenariado hispano a partir de las evidencias arqueológicas (siglos VI - IV a.C.), Venosa.

GRAELLS, R.; LORRIO, A. J.; QUESADA, F. (2014): Cascos hispano-calcídicos. Símbolo de las elites guerreras celtibéricas, Kataloge Vor- und Frühgeschichtlicher Altertümer, Mainz.

HELBIG, W. (1902): Les ippeîs Athéniens, Mémoires de l'Institut National de France, Academie des Inscriptions et Belles Letres 37, 157-264.

DOI: https://doi.org/10.3406/minf.1904.1581

HERMON, E. (1999): Le Lapis Satricanus et la colonisation militaire au début de la République, MÉFRA, 111, 847-881.

DOI: https://doi.org/10.3406/mefr.1999.2100

HOLDER, A. (1896): Alt-Celtischer Sprachschatz I, Leipzig.

HOZ, J. DE (2010-2011): Historia Lingüística de la Península Ibérica en la Antigüedad. I. Preliminares y mundo meridional prerromano. II. El mundo Ibérico prerromano y la indoeuropeización, Madrid.

IZQUIERDO, I. (2000): Monumentos funerarios ibéricos. Los pilares-estela, Serie Trabajos Varios. S.I.P. 98, València.

JIMENO, A.; TORRE, J. I. DE LA; BERZOSA, R.; MARTÍNEZ, J. P. (2004): La necrópolis celtibérica de Numancia, Memorias. Arqueología en Castilla y León 12, Salamanca.

KARAGEORGHIS, V. (1968): Cypre (Archaeologia Mundi), Genève.

KROMMER, K. (1959-1960): Das Gräberfeld von Hallstatt, I-II, Firenze.

KRUTA, V. (1992): L'Europe des origines. La Protohistoire 6000500 avant $J .-C$, Paris.
KUKAHN, E. (1954): Estatuilla de bronce de un guerrero a caballo del poblado ibérico de "La Bastida de les Alcuses (Mogente-Valencia), APL V, 147-158. (=1982): Statueta de bronce d'un guerrer a cavall del poblat iberic de "La Bastida de les Alcuses" (Moixent - València), La Bastida de les Alcuses, 50è Aniversari Declaració Monument Històric-Artístic Nacional (1931-1981), Moixent, 7-13.

LANGLOTZ, E.; HIRMER, M. (1963): Die Kunst der Westgriechen, München.

LANTIER, R. (1935): Bronzes votifs ibériques, Paris.

LAURENDI, R. (2011): La monarchia etrusca a Roma ed il nomen di Servio Tullio: epos e storia. Dati e considerazioni sulla tavola di Lione e la Tomba François, Polis 3, 123-146.

LAYARD, A. (1867): Nineveh and its remains, London.

LENGYEL, L. (1969): Le secret des celtes, Choysie-le-Roy.

LORRIO, A. J. (2005): Los Celtíberos, Biblioteca Archaeologica Hispana 25, Complutum Extra, 7, Madrid ( $1^{\mathrm{a}}$ ed. 1997).

LORRIO, A. J. (2006): Un nuevo estandarte ibérico procedente de Montilla (Córdoba), Boletín de la Asociación Provincial de Museos Locales de Córdoba 7, 167-173.

LORRIO, A. J. (2010): Los signa equitum celtibéricos: origen y evolución, Serta Palaeohispanica in hororem Javier de Hoz (Palaeohispanica 10), Zaragoza, 427-446.

LORRIO, A. J.; ALMAGRO-GORBEA, M. (2004-2005): Signa equitum en el mundo ibérico. Los bronces tipo Jinete de La Bastida y el inicio de la aristocracia ecuestre ibérica, $\mathrm{Lu}$ centum 23-24, 37-60. DOI: https://doi.org/10.14198/LVCENTVM2004-2005.23-24.03

LORRIO, J. A.; GRAELLS, R. (2011-2012): Nuevo "signum equitum” celtibérico, BSAA Arqueología, 77-78, 203-218.

LUBTCHANSKY, N. (2005): Le cavalier tyrrhénien. Représentations équestres dans l'Italie archä̈que, Rome.

MALUQUER DE MOTES, J. (1970): Tartessos. La ciudad sin historia, Barcelona, Destino (reed. 1990).

MANCA, M. L.; WEIDIG, J. (2014): Spoleto 2700 anni fa. Sepolture principesche dalla necropoli di Piazza d'Armi. I piccoli principi di Spoleto, sepolture infantili dalla necropoli di Piazza d'Armi, Gli scettri del re, insegne di potere nella Spoleto preromana, Spoletto.

MANSO, E. (2005): Representaciones de caballos: Fíbula de caballito. Remate de estandarte. Exvoto de jinete, El descubrimiento de los vettones. Los materiales del Museo Arqueológico Nacional (VV.AA.), Ávila, 130-131.

MARTÍN RUIZ, J. A. (2009): La muerte en una colonia fenicia de Occidente. Las necrópolis fenicias de Málaga, Madrider Mitteilungen 50, 149-157.

MÉLIDA, J. R.; ÁLVAREZ, A.; GÓMEZ SANTA CRUZ, S.; TARACENA, B. (1924): Ruinas de Numancia. Memoria descriptiva, Memoria de la Junta Superior de Excavaciones y Antigüedades 61, Madrid.

MENDOZA, A.; MOLINA, F.; ARTEAGA, O.; AgUAYO, P. (1981): Cerro de los Infantes (Pinos Puente, Provinz Granada), Madrider Mitteilungen 22, 171-215. 
MELOTTI, M. (2001): Tra scettro e bastone. L'imaginario greco del potere, Siena.

MELOTTI, M. (2003): Lo scettro di Zeus. Sul l'immaginario greco del potere, Potere sovrano: simboli, limiti, abusi (S. Simonetta, ed.), Bologna, 19-39.

MERHAV, R. 1980): The Palmete on Steatite Bowls in Relation to the Minor Arts and Architecture, Israel Museum News 26, 89-106.

METZGER, H.; BERCHEM, D. VAN (1967): Hippeis, Gestalt und Geschichte. Festschrift K. Schefold, Bern, 155-158.

MOLINA, F.; MENDOZA, A.; SÁEZ, L.; ARTEAGA, O.; AGUAYO, P.; ROCA, M. (1983): Nuevas aportaciones para el estudio del origen de la Cultura Ibérica en la Alta Andalucía. La campaña de 1980 en el Cerro de los Infantes, XVI CNA (Murcia-1982), Zaragoza, 689-708.

MOMMSEN, Th. (1893): Le droit public romain, III, Paris.

MONEO, T. (2004): Religio Iberica. Santuarios, ritos y divinidades (siglos VII-I a.C.), Bibliotheca Archaeologica Hispana 20, Madrid.

MORENO CONDE, M. (2006): Exvotos ibéricos. Instituto Valencia de Don Juan 1, Madrid.

MORET, P. (1996): Les fortifications ibériques de la fin de l'Âge du bronze à la conquête romaine, Madrid.

MUÑOZ, A. M. (1983): Cipo funerario ibérico decorado con esculturas, XVI CNA (Murcia-Cartagena 1982), Zaragoza, 741-748.

MUÑOZ, A. M. (1987): La escultura funeraria de la necrópolis de Coimbra del Barranco Ancho (Jumilla, Murcia), APL XVII, 229-255.

NEGUERUELA, I. (1990): Los monumentos escultóricos ibéricos del Cerrillo Blanco de Porcuna (Jaén), Madrid.

NICOLINI, G. (1969): Les bronzes figurés des sanctuaires ibériques, Paris.

NICOLINI, G. (1977): Bronces ibéricos, Barcelona.

NONY, C. (1969): Une nouvelle interprétation des bronzes d'Azaila, Mélanges de la Casa de Velázquez V, 5-30. DOI: https://doi.org/10.3406/casa.1969.991

ORTHMANN, W. (1971): Untersuchungen zur späthettitischen Kunt, Bonn.

ORTIZ (1996): Faszination der Antike. The George Ortiz Collection, Berlin.

PAGE DEL POZO, V. (1984): Imitaciones de influjo griego en la cerámica ibérica de Valencia, Alicante y Murcia, Hispania Graeca 1, Madrid.

PARIS, P. (1903-1904): Essai sur l'art et l'industrie de l'Espagne primitive, I-II, Paris.

PARROT, A. ; CHEHAB, M. H. ; MOSCATI, S. (1975): Les Phéniciens, Paris.

PASTOR, J. M. (1998): Estandartes, insignias y heraldos ibéricos y celtibéricos, Emblemata. Revista Aragonesa de Emblemática 4, 11-48.

PEREIRA, J. ; SÁNCHEZ, C. (1985): Imitaciones ibéricas de vasos áticos en Andalucía, Ceràmiques gregues i hellenístiques a la Peninsula Ibèrica, Barcelona, 87-102.
PFLUG, H. (1988): Korinthische Helme, Antike Helme. Sammlung Lipperheide und andere Bestände des Antikenmuseums Berlin, Mainz, 87-99.

PRADOS, L. (1992): Exvotos ibéricos de bronce del Museo Arqueológico de Nacional, Madrid.

QUESADA, F. (1997): El armamento ibérico. Estudio tipológico, geográfico, funcional, social y simbólico de las armas en la Cultura Ibérica (siglos VI-I a.C.), Monographies Instrumentum 3, Montagnac.

RAMOS LOSCERTALES, J. Mª (1924): La 'devotio' ibérica, Anuario de Historia del Derecho Español 1924, 7-26.

RIDLEY, R. (2015): The puzzles of Porsenna, Studi Etruschi 78, $77-95$.

RIDLEY, R. (2017): Lars Porsenna and the Early Roman Republic, Antichthon 51, 33-58.

DOI: https://doi.org/10.1017/ann.2017.5

RIPOLLÈS, P. P. (1999): De nuevo sobre la localización de Ikale(n) sken, $1^{a s}$ Jornadas de Arqueología Ibérica en Castilla-La Mancha, Toledo, 145-168.

RODRÍGUEZ ADRADOS, F. (1946): La 'Fides' ibérica, Emérita 14, 128-209.

RODRÍGUEZ DÍAZ, A. (1991): Proyecto Hornachuelos (Ribera del Fresno, Badajoz): 1986-1990, I Jornadas de Prehistoria y Arqueología en Extremadura (1986-1990, Extremadura Arqueológica II, Mérida-Cáceres, 283-300.

RODRÍGUEZ DÍAZ, A. (1995a): El 'problema de la Beturia' en el marco del doblamiento protohistórico del Guadiana medio, Homenaje a la Dra. Da Milagro Gil-Mascarell Boscà, Extremadura Arqueológica V, Cáceres-Mérida, 157-175.

RODRÍGUEZ DÍAZ, A. (1995b): El Valle Medio del Guadiana, "Espacio de Frontera" en la Protohistoria del Suroeste (II), Sagvntvm-PLAV 28, 111-130.

RODRÍGUEZ DÍAZ, A. (2003): Hornachuelos (Ribera del Fresno, Badajoz). Guía multimedia (www.hornachuelos.com), Junta de Extremadura.

RODRÍGUEZ DÍAZ, A.; ENRÍQUEZ, J. J. (2001): Extremadura tartésica. Arqueología de un proceso periférico, Barcelona.

RODRÍGUEZ DÍAZ, A.; PÉREZ GUTIÉRREZ, M.; DUQUE, D. (2019): "Estrechando el círculo" de la Fornacis de Ptolomeo: el oppidum de Hornachuelos (Ribera del Fresno, Badajoz), Conimbriga LXIII, 47-99.

ROUILLARD, P. (1997): Antiquités de l'Espagne. Musée des Antiquités Nationales de Saint-Germain-en-Laye. Musée du Louvre, Paris.

RUSSO TAGLIENTE, A. (1998): I cavalieri di Londra e Boston: un gruppo bronzeo da Armento, Mitteilungen des Deutschen Archäologischen Institut, Römische Abteilung 105, 285-294.

SCHULTEN, A. (1931): Numantia. Die Ergebnisse der Ausgrabungen 1905-1912. II. Die Stadt Numantia, München.

SHILOH, Y. (1979): The proto-aeolic capital and israelita ashlar masonry, Quedem 11, Jerusalem. 
SIEVERS, S. (1993): Kriger und Latènezeit, Das keltische Jahrthausend (H. Dannheimer, R. Gebhard, eds.), Mainz, 54-59.

SILGO, L. (2013): Estudio de toponimia ibérica. La toponimia de las fuentes clásicas, monedas e inscripciones, Valencia.

SOTHEBY'S (2010): Sotheby's. Antiquities from the collection of the Late Clarence Day. 07 December 2010, New York.

STEHLE, E. (1991): Dii Penates a Samothracia sublati, Latomus 50 (3), 581-601.

STIBBE, C. M.; COLONNA, G.; DE SIMONE, C.; VERSNEL, H. (1980): Lapis Satricanus. Archaeological, Epigraphical, Linguistic and Historical Aspects of the New Inscription from Satricum, Roma.

TARACENA, B. (1954): Los pueblos celtibéricos, Historia de España I,3 (R. Menéndez Pidal, ed.), 195-299.

TARRADELL, M. (1968): Arte ibérico, Barcelona.

TIR 1995: Tabula Imperii Romani. Hoja J-29. Lisboa (TIR J-29). Emerita. Scallabis. Pax iulia. Gades, Madrid.

TIR 2001: Tabula Imperii Romani. Hoja J-30. Valencia (TIR J-30). Corduba. Hispalis. Carthago Nova. Astigi, Madrid.

TORELLI, M. (1981): Storia degli etruschi, Roma-Bari.

TORELLI, M. (2011): Bellum in privatam curam (Liv. II,49,1). Eserciti gentilizi, sodalitates e isonomia aristocratica in Etruria e Lazio arcaici, Miti di guerra, ritidi pace. La guerra e la pace: un confronto interdisciplinare (Atti del Convegno Torgiano-Perugia 2009) (C. Masseria, D. Loscalzo, eds.), Bari, 225-234.

TORELLI, M. (2018): La “Tumba del Guerrero" del Museo de Málaga, Discurso leído en el acto de su recepción pública en la Real Academia de Bellas Artes de San Telmo, Málaga.

TORRES, M. (2002): Tartessos, Bibliotheca Archaeologica Hispana 14, Madrid.

TOVAR, A. (1974): Iberische Landeskunde II. Die Völker und die Städte des antiken Spanien. 1, Baetica, Baden-Baden.
VILLARONGA, L. (1979): Numismática antigua de Hispania. Iniciación a su estudio, Barcelona.

VILLARONGA, L. (1994): Corpus nummum Hispaniae ante Augusti aetatem, Madrid.

UNTERMANN, J. (1975): Monumenta Linguarum Hispanicarum I. Die Münzlegenden, Wiesbaden.

UNTERMANN, J. (1985): Lenguas y unidades políticas del Suroeste hispánico en época prerromana, De Tartessos a Cervantes, Köln.

VERNOLE, E. (2002): Servio Tullio, Roma.

VIVES-FERRÁNDIZ, J. (2013): Del espacio doméstico a la estructura social en un oppidum ibérico. Reflexiones a partir de la Bastida de les Alcusses, De la estructura doméstica al espacio social. Lecturas arqueológicas del uso social del espacio (S. Gutiérrez, I. Grau, eds.), Alicante, 95-111.

VOGT, I (1991): Studien zu Pferd und Ritter in der frühgrichische Kunt, Bonn (Tesis Doctoral, no consultada).

WACE (2011): Rupert Wace. Ancient Art 2011. London (http: // www.rupertwace.co.uk/catalogue/catalogue2011.htm).

WACE (2016): Rupert Wace. Ancient Art 2016. London (http: // www.rupertwace.co.uk/catalogue/catalogue2016.htm).

WALTERS, H. B. (1915): Catalogue of the Bronzes, Greek, Roman and Etruscan, in the British Museum, London.

WEIDIG, J. (2014): Bazzano. Ein Gräberfeld bei L'Aquila (Abruzzen). I. Die Bestattungen des 8.-5. Jahrhunderts v. Chr. Untersuchungen zu Chronologie, Bestattungsbräuchen und Sozialstrukturen im apenninischen Mittelitalien, Mainz, 2014.

WEIDIG, A.; BRUNI, N. (2017): The inheritance of power: King's sceptres and the infant princes of Spoleto, Umbria, Etruscan News 19, 1-7.

WOYSH-MÉAUTIS, D. (1982): La représentation des animaux et des êtres fabuleux sur les monuments funéraires grecs de l'époque archaïque à la fin du IVe siècles av. JC., Lausanne. 